\title{
Impact of Winter Soil Processes on Nutrient Leaching in Cold Region Agroecosystems
}

by

Konrad Jens Krogstad

\author{
A thesis \\ presented to the University of Waterloo \\ in fulfilment of the \\ thesis requirement for the degree of \\ Master of Science \\ in \\ Earth Sciences (Water)
}

Waterloo, Ontario, Canada, 2021

(C) Konrad Jens Krogstad 2021 


\section{Author's Declaration}

This thesis consists of material all of which I authored or co-authored: see Statement of Contributions included in the thesis. This is a true copy of the thesis, including any required final revisions, as accepted by my examiners. I understand that my thesis may be made electronically available to the public. 


\section{Statement of Contributions}

The second chapter of this thesis consists of a co-authored manuscript-format paper written for publication. The manuscript presented in this chapter was written by me and has subsequently been reviewed by co-authors. Chapters 2 and 3 outline laboratory experiments. I designed the experiments described in these chapters with Grant Jensen, Fereidoun Rezanezhad, Philippe Van Cappellen, and Laura Hug and advice from my advisory committee David Rudolph. Grant Jensen and I conducted the experiments and I performed analysis with assistance from Marianne VanderGriendt. Mehdi Gharasoo constructed and designed the simple plug flow reactor model

detailed in the manuscript (Chapter 2). The timeline and methodology of the experiment outlined in Chapter 3 were altered by the onset of the COVID-19 pandemic. 


\section{Abstract}

High-latitude cold regions are warming more than twice as fast as the rest of the planet, with the greatest warming occurring during the winter. Warmer winters are associated with shorter periods of snow cover, resulting in more frequent and extensive soil freezing and thawing. Freezethaw cycles (FTC) influence soil chemical, biological, and physical properties and any changes to winter soil processes may impact carbon and nutrients export from affected soils, possibly altering soil health and nearby water quality. Changes to non-growing season climate affect soil biogeochemical processes and fluxes and understanding these changes is critical for predicting nutrient availability in cold region ecosystems and their impacts on downstream water quality.

These impacts are relevant for agricultural soils and practices in cold regions as they are important in governing water flows and quality within agroecosystems. Agricultural systems are source areas for nutrient pollutants due to fertilizer use and have been the target of numerous management strategies. Sustainable agricultural practices have been increasingly employed to mitigate nutrient loss due to erosion, but nutrient export via surface runoff, subsurface leaching, and volatilization allows for continued high nutrient losses (Beach et al., 2018; King et al., 2017).

Chapter 1 of thesis discusses the non-growing season climate changes altering winter soil processes and reviews the major nitrogen transformation processes leading to nitrogen losses in agricultural soils. In Chapter 2, I present a soil column experiment to assess the leaching of nutrients from fertilized agricultural soil during the non-growing season. Four soil columns were exposed to a non-growing season temperature and precipitation model and fertilizer amendments were made to two of the columns to determine the efficacy of fall-applied fertilizers and compared to other two unfertilized control columns. Leachates from the soil columns were collected and 
analyzed for cations and anions. The experiment results showed that a transition from a freeze period to a thaw period resulted in significant loss of chloride $\left(\mathrm{Cl}^{-}\right)$, sulfate $\left(\mathrm{SO}_{4}{ }^{2-}\right)$ and nitrate $\left(\mathrm{NO}_{3}{ }^{-}\right)$. Even with low $\mathrm{NO}_{3}{ }^{-}$concentrations in the applied artificial rainwater and fertilizer, high $\mathrm{NO}_{3}{ }^{-}$concentrations $\left(\sim 150 \mathrm{mg} \mathrm{L}^{-1}\right)$ were observed in fertilized column leachates. Simple plug flow reactor model results indicate the high $\mathrm{NO}_{3}{ }^{-}$leachates are found to be due to active nitrification occurring in the upper oxidized portion of the soil columns mimicking overwinter $\mathrm{NO}_{3}{ }^{-}$losses via nitrification in agricultural fields. The low $\mathrm{NO}_{3}{ }^{-}$leachates in unfertilized columns suggest that FTC had little effect on $\mathrm{N}$ mineralization in soil.

In Chapter 3, I provide a brief review of nitrification inhibitors and how soil properties impact nitrification inhibitor efficacy. There are only a few studies on the relationship between nitrification inhibitor efficacy and climatic factors, especially in regard to FTC. I conducted a sacrificial soil batch experiment to determine if and how nitrification inhibitors were impacted by FTC to further explore the results of Chapter 2. The batch experiment revealed the nitrification inhibitors were effective at mitigating $\mathrm{NO}_{3}{ }^{-}$production under freeze-thaw conditions but more effective at mitigating these losses under thaw conditions. The soils exposed to the FTC condition experienced significant $\mathrm{N}$ mineralization flushes in contrast to the lack of mineralization induced by FTCs in the experiment detailed in Chapter 2 .

In Chapter 4, I summarize the key findings of this thesis. The results showed fertilizer loss and nitrification inhibitor effectiveness are affected by freeze-thaw cycling in arable soil. The experimental and modeling results reported in this thesis could be used to bolster winter soil biogeochemical models by elucidating nutrient fluxes over changing winter conditions to refine best management practices for fertilizer application. Ultimately, these results and the conclusions 
drawn from them highlight several research pathways that could be undertaken to progress our understanding of the complex interactions between FTC and fertilizer dynamics. 


\section{Acknowledgements}

I would like to thank Fereidoun Rezanezhad and Philippe Van Cappellen for providing me with the opportunity to work on this project as part of the Ecohydrology Research Group. Fereidoun, thank you for your support and guidance. They have been invaluable. Phillippe, thank you for your expertise and questions that always made me consider something new.

I would like to thank Laura Hug for your words of advice and opening me to the biological side of my research. I would like to thank Grant Jensen for being my research partner throughout this project. Our conversations about research and life helped me overcome many obstacles and made the most arduous sampling days enjoyable. I would like to thank David Rudolph for your thoughtful input about my research.

I would like to thank Marianne Vandergriendt for the immense assistance you provided me in the lab and in designing my experiments. Without your instructions and advice, I would have struggled to navigate and execute my experimental methodologies.

I would like to thank the rare Charitable Research Reserve and Jenna Quinn for supporting and accommodating this research project. I would also like to thank the Ecohydrology Research Group members for listening to my talks and providing useful suggestions; Thank you Mehdi for enlightening me about flow reactor models and being patient with me; Thank you Linden, Heather, Steph and Nady for assisting me, supporting me, and answering my questions; Thank you Shuhuan for spending the time to teach me how to operate the SEM; Thank you Laurel for helping me in the lab with my second experiment. 
I would like to thank my parents, Tracey and Eirik, for their unending support, encouragement, and guiding me to where I am today. Finally, I would like to thank Charity for listening to me, going with me for long walks, and for putting up with my jokes. 


\section{Table of Contents}

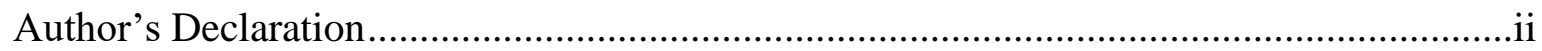

Statement of Contributions ................................................................................................

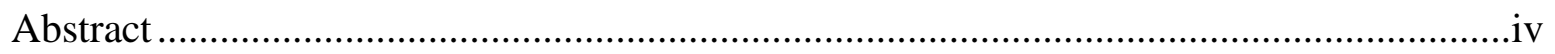

Acknowledgements .....................................................................................................vii

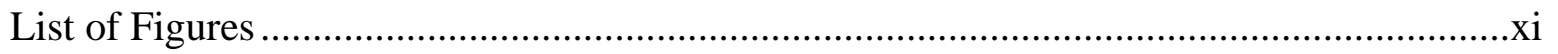

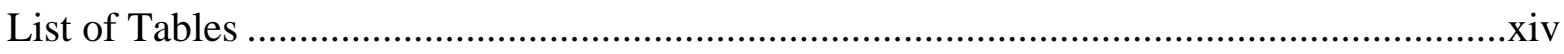

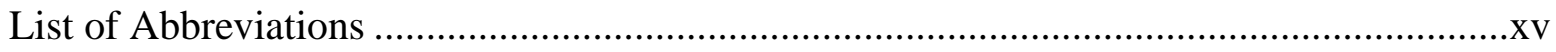

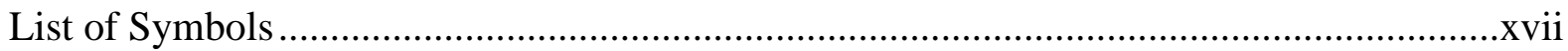

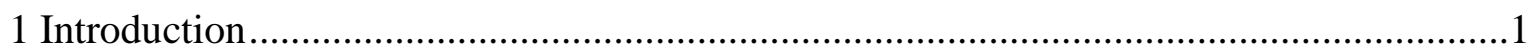

1.1 Impact of Climate Change on Winter Soil Processes ...............................................1

1.2 Freeze-thaw Cycling in Soils and Agroecosystems..................................................

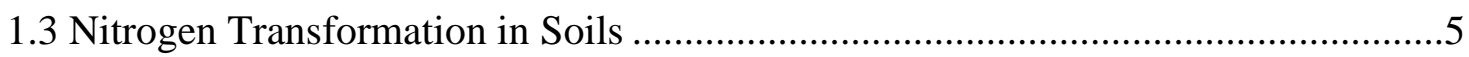

1.3.1 Forms of Nitrogen in the Terrestrial Nitrogen Cycle...........................................

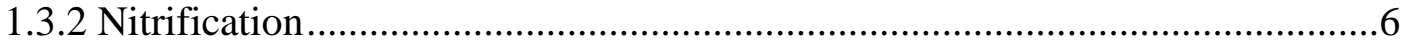

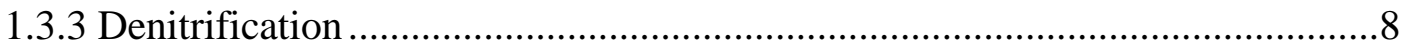

1.3.4 Agricultural Soil Nitrogen Mineralization........................................................10

1.4 Nutrient Management in Agroecosystems ................................................................11

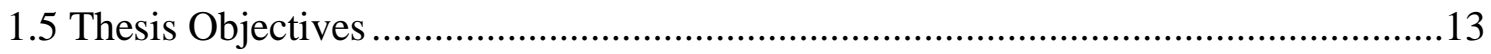

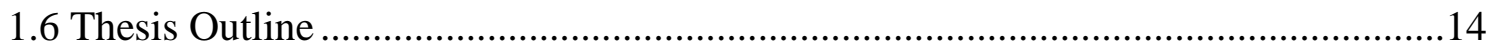

2 Impact of Winter Soil Processes on Nutrient Leaching in Cold Region Agroecosystems.15

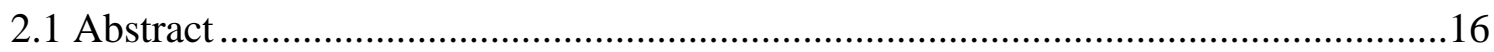

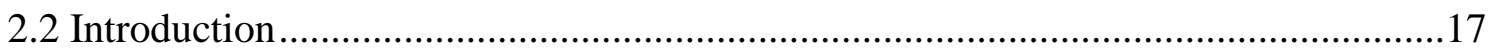

2.3 Materials and Methods......................................................................................20

2.3.1 Soil Collection and Properties …………………......................................20

2.3.2 Experimental Freeze-thaw Soil Column System .............................................21

2.3.3 Environmental Chamber Temperature and Precipitation Regimes ...................23

2.3.4 Fertilizer Amendments and Artificial Rainwater..............................................25

2.3.5 Leachate Sampling and Analytical Methods .................................................25

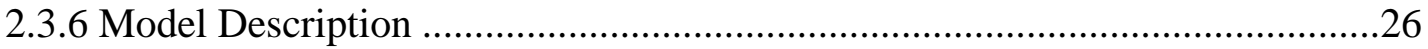




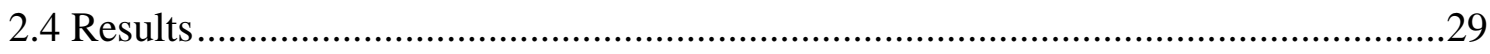

2.4.1 Temperature Regimes in the Soil Columns ...................................................29

2.4.2 Soil Column Leachates ..................................................................................

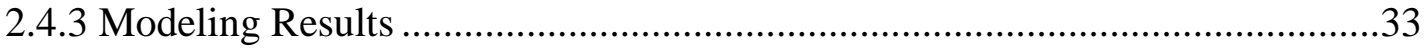

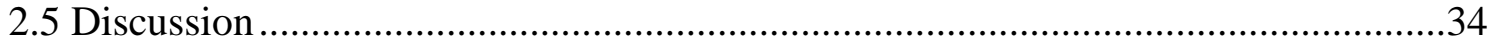

2.5.1 Impact of Winter Processes on Chloride and Sulfate Leachates .......................34

2.5.2 Impact of Winter Processes on Nitrate Leachates .............................................35

2.5.3 Modeling Nitrogen Transformations and Losses...............................................36

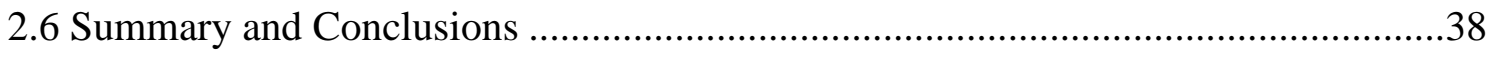

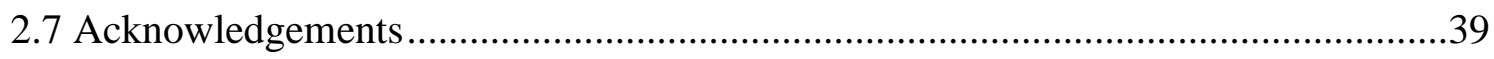

3 Investigating the Effect of Freeze-thaw Cycling on Nitrification Inhibitor Efficacy ..........40

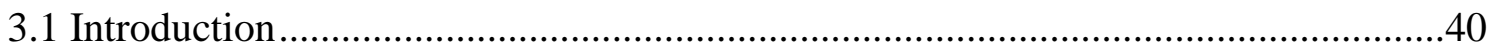

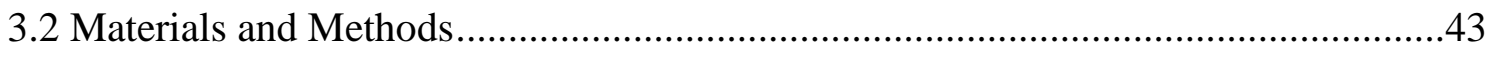

3.2.1 Soil Collection and Properties .......................................................................43

3.2.2 Sacrificial Soil Jar Batch Experiment ...............................................................43

3.2.3 Pore water Sampling and Analytical Methods..................................................45

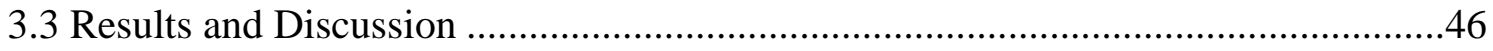

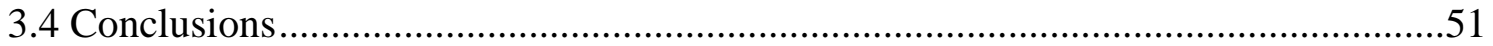

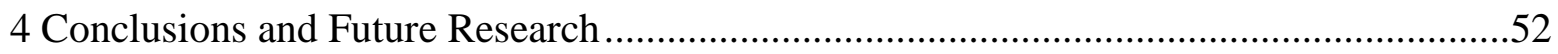

4.1 Summary of Key Findings ..................................................................................52

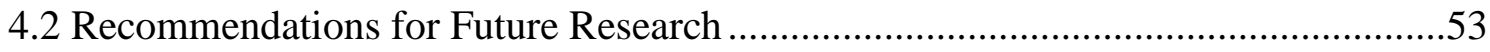

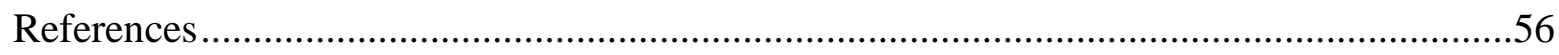

Appendix: Additional Experimental Information and Results from Chapters 2 and 3..........76 


\section{List of Figures}

Figure 1-1: Projected change in seasonal surface temperature between 2070-2090 relative to 19601990 in the upper northern hemisphere. Figure adapted from AMAP (2012).

Figure 1-2: Conceptual graph showing the expected soil temperature changes with increasing average seasonal temperatures. The solid line represents current soil temperatures while the dashed line represents expected future soil temperatures.

Figure 1-3: Diagram of the effects of freeze-thaw cycling on soil chemical, biological, and physical processes that control carbon and nutrient cycling as well as microbial activity (Figure adapted from Hayashi, 2013).

Figure 2-1: Schematic showing the two control columns (unfertilized) and two experimental columns (fertilized). Temperature sensors were installed at $+2.5,-3.5,-7,-15.5$, and $-33 \mathrm{~cm}$ relative to the soil surface in one of the control columns. The column on the right is showing the concept used for the simple plug flow reactor model with three zones (see 2.2.6).

Figure 2-2: The top graph shows total applied volume of artificial rainwater over the course of the experiment. The bottom graph shows air temperature and soil temperature at various depths over the course of the experiment. Soil temperatures were measured at different depths below the soil surface in one of the columns and treated as representative for all columns. .24

Figure 2-3: Photos of the soil column setup (A) and fertilizer applied on soil surface in fertilized columns (B) 26

Figure 2-4: Temperature and leachate $\mathrm{Cl}^{-}$concentrations versus time for fertilized and unfertilized columns. 
Figure 2-5: Temperature and leachate $\mathrm{SO}_{4}{ }^{2-}$ concentrations versus time for fertilized and unfertilized columns.

Figure 2-6: Temperature and leachate $\mathrm{NO}_{3}{ }^{-}$concentrations versus time for fertilized and unfertilized columns. 32

Figure 2-7: Model fit of reactions to the averaged $\mathrm{NO}_{3}{ }^{-}$concentrations measured in the fertilized soil columns and simulation of other nitrogen transformation processes in three zones 0,1 and 2 used for the simple plug flow reactor model. A list of parameters and their estimated values are presented in Table 1

Figure 3-1: Photos of freeze-thaw cycle soil jars in Percival environmental chamber following saturation and addition of fertilizer and inhibitors to appropriate jars (A) and fridge used for storing samples at the thaw condition and environmental chambers used for storing samples at frozen and freeze-thaw cycle condition (B).

Figure 3-2: $\mathrm{NO}_{3}{ }^{-}$concentrations versus time for unfertilized, fertilized, and inhibited samples in the freeze condition. 46

Figure 3-3: $\mathrm{NO}_{3}{ }^{-}$concentrations versus time for unfertilized, fertilized, and inhibited samples in the thaw condition. 48

Figure 3-4: $\mathrm{NO}_{3}{ }^{-}$concentrations versus time for unfertilized, fertilized, and inhibited samples in the FTC condition.

Figure A-1: Temperature and leachate $\mathrm{pH}$ versus time for fertilized and unfertilized columns presented in Chapter 2. 76

Figure A-2: Chloride $\left(\mathrm{Cl}^{-}\right)$concentrations versus time for unfertilized, fertilized, and inhibited soil samples under freeze $\left(-10^{\circ} \mathrm{C}\right)$, thaw $\left(4^{\circ} \mathrm{C}\right)$, and freeze-thaw cycle (FTC) (between $-10^{\circ} \mathrm{C}$ and $4{ }^{\circ} \mathrm{C}$ ) conditions presented in Chapter 3. 
Figure A-3: Sulfate $\left(\mathrm{SO}_{4}{ }^{2-}\right)$ concentrations versus time for unfertilized, fertilized, and inhibited soil samples under freeze $\left(-10^{\circ} \mathrm{C}\right)$, thaw $\left(4^{\circ} \mathrm{C}\right)$, and freeze-thaw cycle (FTC) (between $-10^{\circ} \mathrm{C}$ and

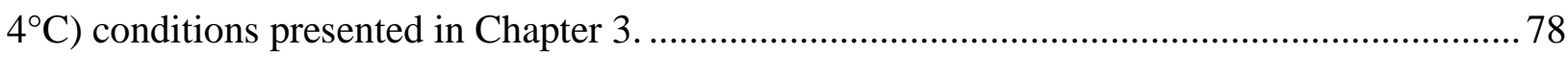

Figure A-4: Dissolved organic carbon (DOC) concentrations versus time for unfertilized, fertilized, and inhibited soil samples under freeze $\left(-10^{\circ} \mathrm{C}\right)$, thaw $\left(4^{\circ} \mathrm{C}\right)$, and freeze-thaw cycle (FTC) (between $-10^{\circ} \mathrm{C}$ and $4^{\circ} \mathrm{C}$ ) conditions presented in Chapter 3...................................... 79

Figure A-5: Dissolved inorganic carbon (DIC) concentrations versus time for unfertilized, fertilized, and inhibited soil samples under freeze $\left(-10^{\circ} \mathrm{C}\right)$, thaw $\left(4^{\circ} \mathrm{C}\right)$, and freeze-thaw cycle

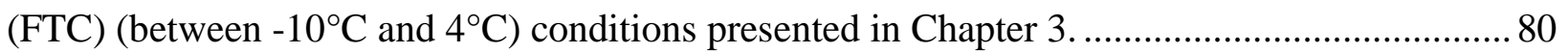

Figure A-6: Total nitrogen (TN) concentrations versus time for unfertilized, fertilized, and inhibited soil samples under freeze $\left(-10^{\circ} \mathrm{C}\right)$, thaw $\left(4^{\circ} \mathrm{C}\right)$, and freeze-thaw cycle (FTC) (between $10^{\circ} \mathrm{C}$ and $4^{\circ} \mathrm{C}$ ) conditions presented in Chapter 3 . 


\section{List of Tables}

Table 2.1: List of parameters values used for model simulation and estimated parameters from the optimization of Equations 5 to the measured data. Reaction energies for the reactions 2, 3, and 4 were obtained from McKenney et al., 1984; Ambus, 1993; Saad and Conrad, 1993; and Maag et al., 1997.

Table A-1: Tables showing water-filled pore space values across depth for the soil columns presented in Chapter 2. .82

Table A-2: Tables showing (A) major cation and anion concentrations in artificial rainwater and (B) major anion concentrations in fertilizer utilized in Chapter 2 


\section{List of Abbreviations}

\begin{tabular}{|c|c|}
\hline FTC & Freeze-thaw Cycle \\
\hline GHG & Greenhouse Gas \\
\hline $\mathrm{CO}_{2}$ & Carbon Dioxide \\
\hline $\mathrm{CH}_{4}$ & Methane \\
\hline $\mathrm{N}_{2} \mathrm{O}$ & Nitrous Oxide \\
\hline NO & Nitric Oxide \\
\hline NGS & Non-Growing Season \\
\hline $\mathrm{N}$ & Nitrogen \\
\hline $\mathrm{NH}_{3}$ & Ammonia \\
\hline $\mathrm{NH}_{4}^{+}$ & Ammonium \\
\hline $\mathrm{NO}_{3}^{-}$ & Nitrate \\
\hline $\mathrm{NO}_{2}^{-}$ & Nitrite \\
\hline $\mathrm{AOB}$ & Ammonia Oxidizing Bacteria \\
\hline $\mathrm{AOA}$ & Ammonia Oxidizing Archaea \\
\hline $\mathrm{N}_{2}$ & Dinitrogen \\
\hline WFPS & Water-filled Pore Space \\
\hline $\mathrm{TN}$ & Total Nitrogen \\
\hline SOM & Soil Organic Matter \\
\hline DOC & Dissolved Organic Carbon \\
\hline DIC & Dissolved Inorganic Carbon \\
\hline $\mathrm{PO}_{4}^{3-}$ & Phosphate \\
\hline $\mathrm{Cl}^{-}$ & Chloride \\
\hline
\end{tabular}




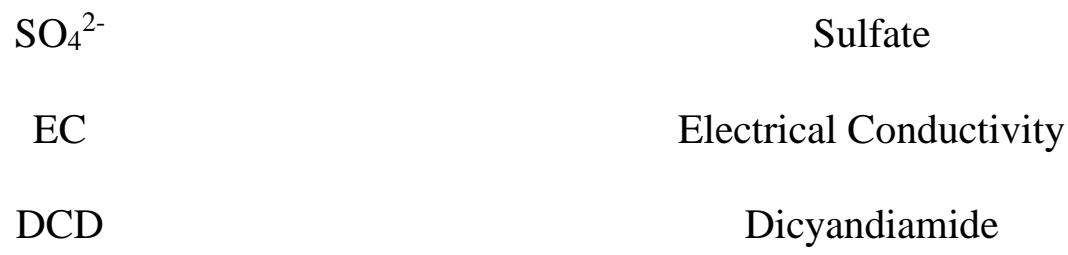

AMO

Ammonia Monooxygenase Enzyme 


\section{List of Symbols}

$\begin{array}{ccc}k_{1} & \text { Rate constant for urea hydrolysis } & \left(\mathrm{day}^{-1}\right) \\ k_{2} & \text { Rate constant for dissolution of ammonia in water } & \left(\mathrm{day}^{-1}\right) \\ k_{3} & \text { Rate constant for nitrification } & \left(\mathrm{day}^{-1}\right) \\ k_{4} & \text { Rate constant for denitrification } & \left(\mathrm{day}^{-1}\right) \\ r D_{x} & \text { Dilution rate to zone } x & \left(\mathrm{day}^{-1}\right) \\ k 0_{I} & \text { Pre-exponential factor for reactions } & \left(\mathrm{day}^{-1}\right) \\ R & \text { Universal gas constant } & \left(\mathrm{J} \mathrm{mol}^{-1} \mathrm{~K}^{-1}\right) \\ E_{a i} & \text { Activation energy } & \left(\mathrm{kJ} \mathrm{mol}^{-1}\right) \\ T & \text { Temperature } & \left(\mathrm{K}^{2}\right)\end{array}$




\section{Introduction}

\subsection{Impact of Climate Change on Winter Soil Processes}

Soils are multi-phase systems in which a variety of crucial chemical, biological, and physical processes occur that allow this natural resource to perform ecological, economic, and social functions (Blum, 2005). These processes are dependent on a variety of factors including temperature, moisture, land use, available nutrients, $\mathrm{pH}$, aeration, organic matter content, and microbial community composition (Buyer et al., 2010; Karlen et al., 1997). Global annual mean temperatures have risen substantially over the past century with much of this warming occurring in the Northern Hemisphere (Hansen et al., 2006) (Figure 1-1). Annual mean Canadian temperatures have increased over this period, with the greatest warming occurring during the winter (Zhang et al., 2000). Most of this warming has occurred in northern regions of Canada, but moderate temperature changes in more temperate regions can drastically alter snow cover dynamics.
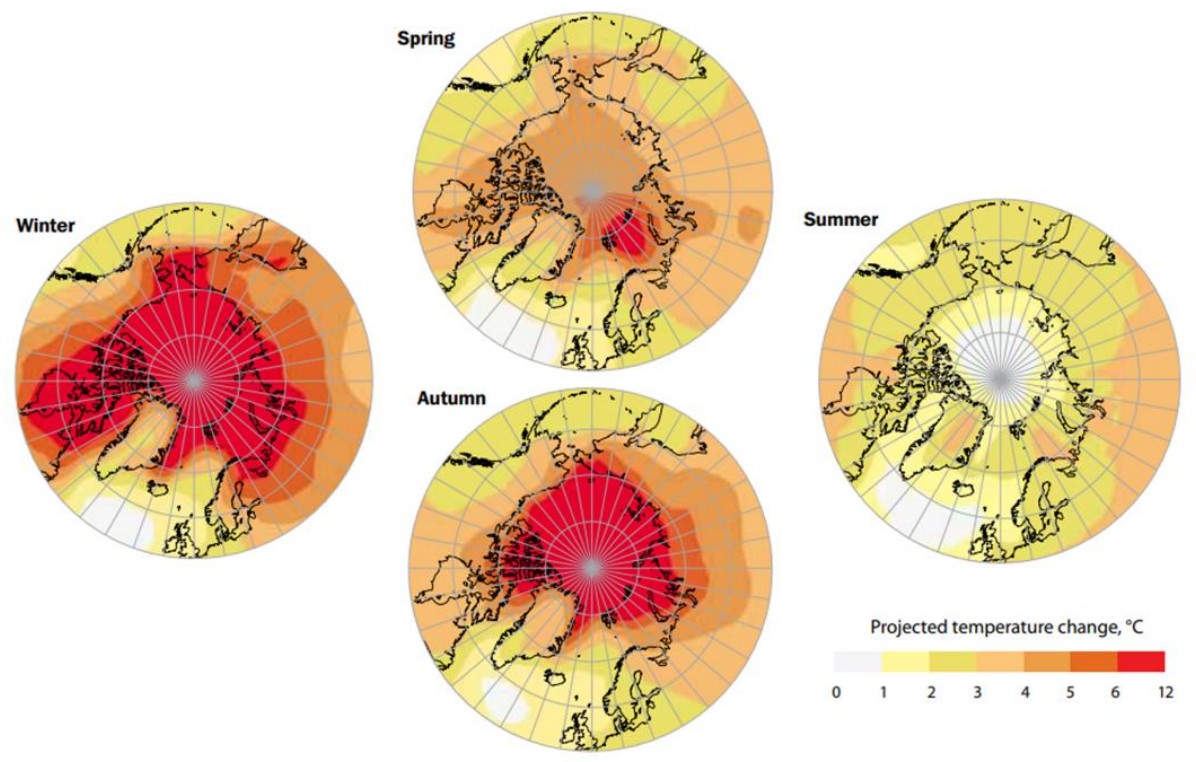

Figure 1-1: Projected change in seasonal surface temperature between 2070-2090 relative to 19601990 in the upper northern hemisphere. Figure adapted from AMAP (2012). 
As winter air temperatures increase, observed and modeled snow cover extent and depth data regionally show consistent decreases and suggest these snow trends will continue in the future (Brown, 2000; Lawrence and Slater, 2010). While winter precipitation rates have been modeled to increase as a result of climate change, a decreasing portion of this precipitation is expected to fall as snow due to rising air temperatures (Krasting et al., 2013). It has been shown that snow cover insulates the underlying soil (Ge and Gong, 2010; Lawrence and Slater, 2010). As snow cover thickness decreases, this insulating effect diminishes. The loss of this insulation will result in soil temperatures decreasing overall, especially in the near surface, resulting in more frequent occurrences of soil freezing and subsequent thawing (Figure 1-2).

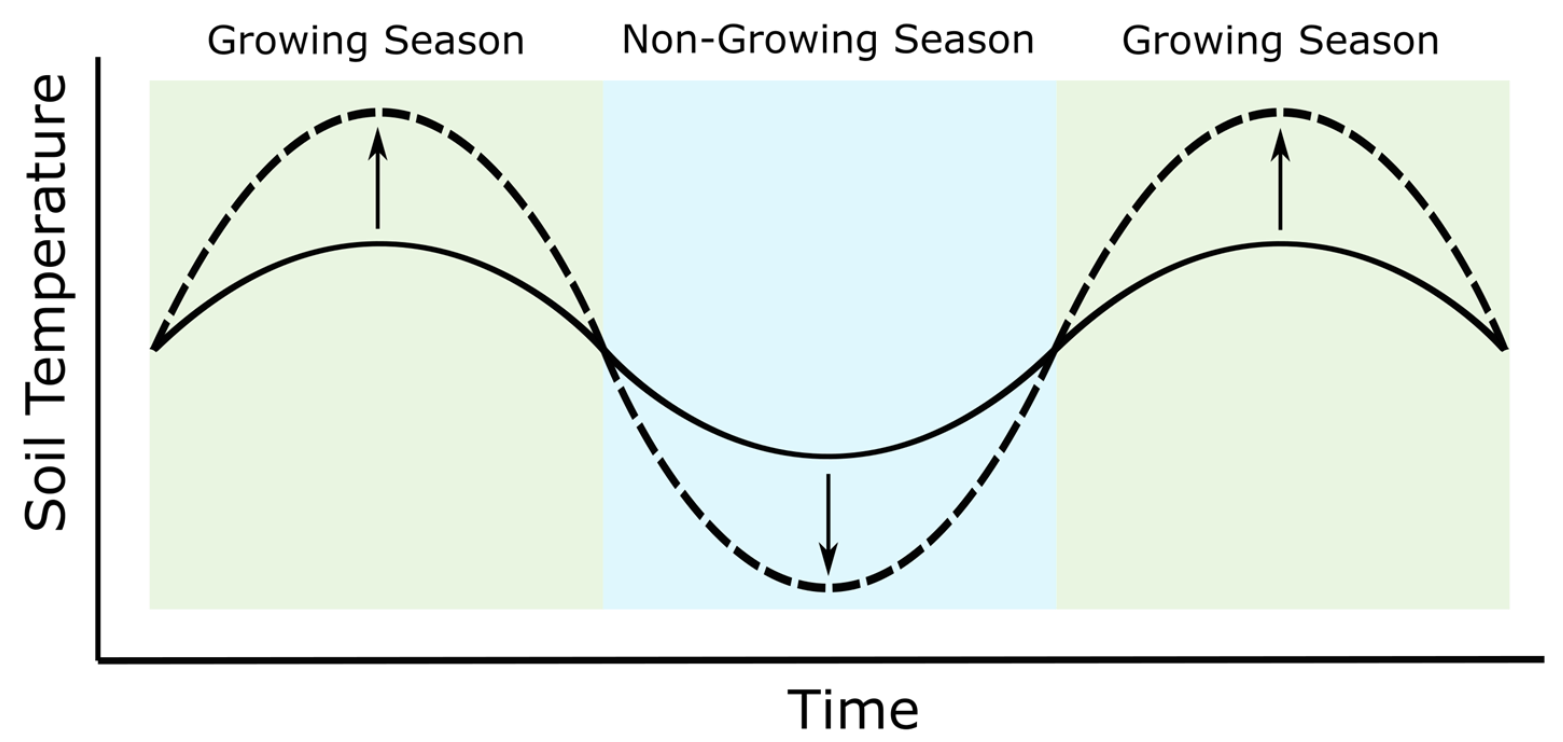

Figure 1-2: Conceptual graph showing the expected soil temperature changes with increasing average seasonal temperatures. The solid line represents current soil temperatures while the dashed line represents expected future soil temperatures. 


\subsection{Freeze-thaw Cycling in Soils and Agroecosystems}

Freeze-thaw cycles (FTCs) influence chemical, biological, and physical processes in soils that control carbon and nutrient cycling as well as microbial activity (Hayashi, 2013; Matzner and Borken, 2008) (Figure 1-3). Expected climate changes will affect the physical structure, chemical composition, and biotic processes in seasonally snow-covered soils, which impact the turnover, retention and export of carbon and nutrients. Our mechanistic understanding of the effects of changing winter conditions on soil biogeochemical processes and fluxes is limited.

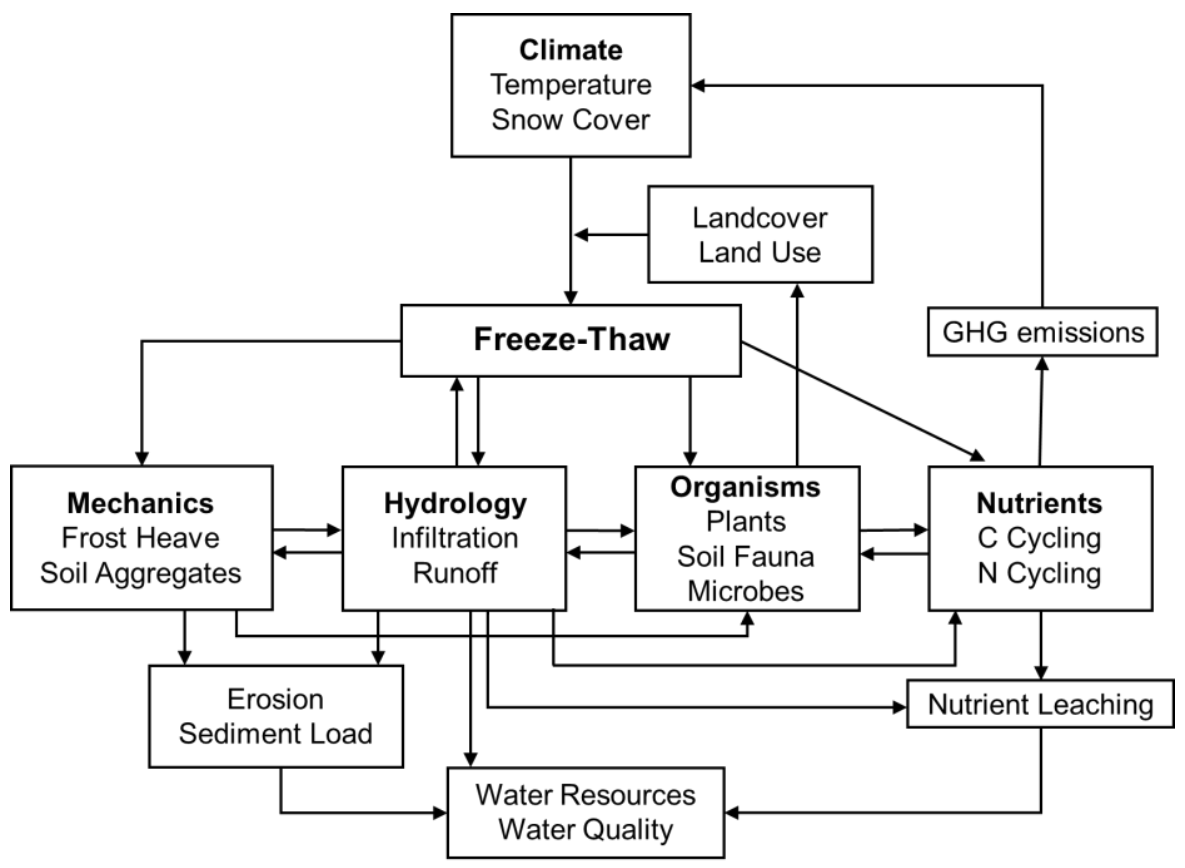

Figure 1-3: Diagram of the effects of freeze-thaw cycling on soil chemical, biological, and physical processes that control carbon and nutrient cycling as well as microbial activity (Figure adapted from Hayashi, 2013).

Soil freezing reduces soil hydraulic conductivity and alters water infiltration properties (Hayashi, 2013). Soil hydraulic conductivity decreases with increasing ice content as ice forms in larger pores first, restricting water flow to smaller pores (McCauley et al., 2002). This process is akin to the decrease in hydraulic conductivity that occurs with decreasing water content except 
larger pores are filled with ice rather than air (Watanabe and Flury, 2008). Snowmelt infiltration in frozen soil is dependent on multiple factors including the continuity of a near surface ice layer, pre-existing macropore networks, and pre-thaw water moisture regime (Gray et al., 2001; Stadler et al., 2000). Infiltration is further altered in agricultural soils as tillage disrupts soil macropore networks, reducing infiltration rates in both unfrozen and frozen soils (Singh et al., 2009). Soil pore water will migrate upwards towards the freezing zone due to the potential gradient formed from the temperature difference between near surface and soil at depth (Hohmann, 1997). This freezing process pushes out soil grains and solutes to the remaining unfrozen water that forms thin, nutrient-rich films (i.e., unfrozen water) around soil aggregates and inside small pores (Risk et al., 2013).

Cold-resistant microbes continue to respire at sub-zero temperatures in the unfrozen water (Nikrad et al., 2016). These microbes in unfrozen waters can produce greenhouse gases (GHGs) such as carbon dioxide $\left(\mathrm{CO}_{2}\right)$, methane $\left(\mathrm{CH}_{4}\right)$, and nitrous oxide $\left(\mathrm{N}_{2} \mathrm{O}\right)$, which accumulate throughout the non-growing season, trapped by the overlying ice layer that limits diffusion (Van Bochove et al., 2001). Thaw events allow for release of these GHGs and renewed microbial activity (Wagner-Riddle et al., 2008a). These processes also affect groundwater quality and nutrient abundance (Nikrad et al., 2016; Risk et al., 2013) and lead to climate feedback, exacerbating future GHG emissions (Figure 1-3).

$\mathrm{N}_{2} \mathrm{O}$ emissions from soils represents the largest flux of $\mathrm{N}_{2} \mathrm{O}$ globally (Butterbach-Bahl et al., 2013; Menon et al., 2007). Over half of these emissions are derived from agricultural soils and a large portion of these emissions occur during the thaw events over the winter (Matzner and Borken, 2008; Reay et al., 2012). Many studies have identified that freeze-thaw derived $\mathrm{N}_{2} \mathrm{O}$ emissions are predominantly sourced from denitrified $\mathrm{NO}_{3}^{-}$(Müller et al., 2002; Risk et al., 2013; 
Wagner-Riddle et al., 2008b) and it has been shown that denitrification is promoted due to anerobic conditions created by gas diffusion limitations (Wagner-Riddle et al., 2017). While FTCs have largely been demonstrated to drive denitrification, Müller et al. (2002) reported that nitrification rates increase during the post-thaw period and Yanai et al. (2004) observed FTCs may increase soil nitrification depending on soil type and $\mathrm{pH}$. FTCs thereby have the potential to generate conditions favoring both nitrification and denitrification, causing large shifts in the direction nitrogen $(\mathrm{N})$ transformations with significant implications for $\mathrm{N}$ loss and the way it is lost.

\subsection{Nitrogen Transformation in Soils}

\subsubsection{Fluxes and Forms of Nitrogen in the Terrestrial Nitrogen Cycle}

Soil $\mathrm{N}$ is composed of many organic and inorganic forms (Keeney and Nelson, 1983; Stevenson, 1982). Organic $\mathrm{N}$ is a component of soil organic matter (SOM) that comprises almost of soil $\mathrm{N}$ and a majority of this soil organic $\mathrm{N}$ exists as amino acids and proteins (Hatten and Liles, 2019). Microorganisms can release $\mathrm{N}$ from these organic compounds via mineralization, making it bioavailable for other soil organisms (Ollivier et al., 2011). This decomposition process is one of several means by which $\mathrm{N}$ is input into soil systems. Molecular $\mathrm{N}$ (in the form of $\mathrm{N}_{2}$ ) in the atmosphere is primarily fixed biologically by prokaryotes to form ammonia $\left(\mathrm{NH}_{3}\right)$ (Fields, 2004; Noxon, 1976). Anthropogenic $\mathrm{N}$ inputs are the largest source of $\mathrm{N}$ to soil systems, having more than doubled terrestrial $\mathrm{N}$ loading since the onset of the industrial revolution (Green et al., 2004). Atmospheric $\mathrm{N}$ deposition, fertilizer use, and food and feed transport dominate soil $\mathrm{N}$ input fluxes (Boyer et al., 2002; Lassaletta et al., 2014). Inorganic $\mathrm{N}$ in fertilizer is commonly found in the forms of $\mathrm{NH}_{4}$ and $\mathrm{NO}_{3}{ }^{-}$(Finch et al., 2014). Plant preference for these two inorganic species varies, but unassimilated $\mathrm{NH}_{4}$ and $\mathrm{NO}_{3}{ }^{-}$is susceptible to oxidization and reduction via nitrification and denitrification, respectively (Singh et al., 2008). These processes may result in N converted to 
labile gaseous and solute compounds $\left(\mathrm{N}_{2} \mathrm{O}, \mathrm{N}_{2}, \mathrm{NH}_{3}\right.$, and $\left.\mathrm{NO}_{3}^{-}\right)$that can easily escape the soil system (Burney et al., 2010; Quemada et al., 2013; Rochette et al., 2013).

\subsubsection{Urea Hydrolysis and Nitrification}

Urea is one of the most commonly applied forms of $\mathrm{N}$ fertilizer in agricultural practices (Ramirez et al., 2010). Following application, urea is hydrolyzed to an unstable carbamic acid and the acid quickly breaks down into $\mathrm{NH}_{3}$ and $\mathrm{CO}_{2}$ as follows (Sigurdarson et al., 2018):

$$
\left(\mathrm{NH}_{2}\right)_{2} \mathrm{CO}+\mathrm{H}_{2} \mathrm{O} \rightarrow \mathrm{NH}_{3}+\mathrm{H}_{2} \mathrm{NCOOH} \rightarrow 2 \mathrm{NH}_{3(\text { gas })}+\mathrm{CO}_{2(\text { gas })}
$$

This $\mathrm{NH}_{3}$ gas will be lost unless it reacts with water to form ammonium $\left(\mathrm{NH}_{4}{ }^{+}\right)$via the following reaction:

$$
\mathrm{NH}_{3(\text { gas })}+\mathrm{H}_{2} \mathrm{O} \rightarrow \mathrm{NH}_{4}^{+}+\mathrm{OH}^{-}
$$

$\mathrm{NH}_{4}{ }^{+}$is initially oxidized to nitrite $\left(\mathrm{NO}_{2}{ }^{-}\right)$. This action is performed by ammonia oxidizing bacteria (AOB) such as Nitrosomonas and Nitrosospira that first convert $\mathrm{NH}_{4}{ }^{+}$to the intermediate hydroxylamine (Norton and Ouyang, 2019). This net reaction goes as follows (Schleper and Nicol, 2010):

$$
2 \mathrm{NH}_{4}^{+}+3 \mathrm{O}_{2} \rightarrow 2 \mathrm{NO}_{2}^{-}+2 \mathrm{H}_{2} \mathrm{O}+4 \mathrm{H}^{+}+\text {energy }
$$

where the $\mathrm{NO}_{2}{ }^{-}$is then oxidized to $\mathrm{NO}_{3}{ }^{-}$. This action is performed by Nitrobacter and the reaction goes as follows (Sahrawat, 2008):

$$
2 \mathrm{NO}_{2}^{-}+\mathrm{O}_{2} \rightarrow 2 \mathrm{NO}_{3}^{-}+\text {energy }
$$

These steps comprise the traditional nitrification pathway. Nitrifier community abundance and composition may allow for different nitrification pathways to be used but also alter rates of the aforementioned nitrification process (Daims et al., 2015; Ouyang et al., 2018). Nitrification 
rates have been found to be correlated to AOB and ammonia oxidizing archaea (AOA) abundance (Rocca et al., 2015). Understanding soil nitrifier community dynamics is thereby critical for improving our predicative capacity of the nitrification potential of a given soil.

Nitrification rates are also controlled by other environmental factors such as substrate supply, temperature, soil moisture content, and substrate diffusion (Norton and Ouyang, 2019). $\mathrm{NH}_{3}$ oxidizers depend upon ample $\mathrm{NH}_{3}$ supply to perform their function. Higher $\mathrm{NH}_{3}$ concentrations will allow for AOBs and AOAs to operate at their maximum capacity but excessive $\mathrm{NH}_{3}$ concentrations will begin to inhibit $\mathrm{NH}_{3}$ and $\mathrm{NO}_{2}{ }^{-}$oxidizers due to toxicity of the compound (Kim et al., 2006). Urea inputs will result in a spike of $\mathrm{NH}_{3}$ concentrations that quickly decline. Inhibition of $\mathrm{NO}_{2}{ }^{-}$oxidizers via high $\mathrm{NH}_{3}$ allows for the conversion accumulated $\mathrm{NO}_{2}{ }^{-}$to $\mathrm{N}_{2} \mathrm{O}$ and creates a pathway for $\mathrm{N}_{2} \mathrm{O}$ emissions via nitrification (Soares et al., 2016). Overall, the increased availability of $\mathrm{NH}_{3}, \mathrm{NH}_{4}^{+}$, and $\mathrm{NO}_{2}^{-}$largely enhance nitrification rates but may suppress rates if substrate supply surpasses the capacity of the nitrifying community.

Nitrification rates are directly related to temperature, increasing with temperature until reaching temperature optimums (Shammas, 1986). Soil nitrifying microbes generally have temperature optimums ranging between $25-35^{\circ} \mathrm{C}$ and wide temperature tolerance ranges, with nitrification recorded from soil sites with temperatures as low as $2^{\circ} \mathrm{C}$ and as high as $35-40^{\circ} \mathrm{C}$ (Taylor et al., 2017). Several studies have noted that AOB and AOA have overlapping but distinct nitrification potentials relative to temperature (Hu et al., 2015; Tourna et al., 2008). At lower temperatures, nitrification is almost entirely sustained by AOB with nitrification at higher temperatures sustained by AOA (Ouyang et al., 2017).

Moisture content has also a wide range of impacts on soil nitrification. If water-filled pore space (WFPS) is low, reduced substrate diffusion and dehydration of nitrifying organisms will 
limit nitrification rates while high enough WFPS can significantly reduce aeration, which will similarly limit nitrification rates (Bateman and Baggs, 2005; Bollmann and Conrad, 1998). WFPS between $40-55 \%$ are shown to be optimal for nitrification depending on soil texture, with finer soils having a higher optimum than coarser soils (Parton et al., 2001).

\subsubsection{Denitrification}

Denitrification is a process that involves the reduction of the solid, ionic $\mathrm{N}$ species $\left(\mathrm{NO}_{2}{ }^{-}\right.$ and $\mathrm{NO}_{3}{ }^{-}$) to the gaseous $\mathrm{N}$ species $\left(\mathrm{NO}, \mathrm{N}_{2} \mathrm{O}\right.$, and $\mathrm{N}_{2}$ ) under oxygen-limiting conditions (Knowles, 1982; Schlüter et al., 2018). The denitrification pathway can be characterized by the following sequence of reductions (Zumft, 1997):

$$
\mathrm{NO}_{3}^{-} \rightarrow \mathrm{NO}_{2}^{-} \rightarrow \mathrm{NO} \rightarrow \mathrm{N}_{2} \mathrm{O} \rightarrow \mathrm{N}_{2}
$$

This form of $\mathrm{NO}_{3}$ reduction is a dissimilatory phenomenon that results in the formation of $\mathrm{N}$ gas (Shapleigh, 2009). A series of enzyme groups named after the enzyme substrate mediate these conversions and are thereby called nitrate, nitrite, nitric, and nitrous oxide reductase, respectively (Zumft, 1997).

Soil denitrification is spatially variable and dependent on environmental factors with small microsites responsible for most denitrification (Parkin, 1987). The formation of denitrification "hot spots" is largely dependent upon the presence of $\mathrm{N}$ and organic carbon substrates, $\mathrm{pH}$, temperature, and the physical properties of the soil environment (Schlüter et al., 2018). While substrate concentration may enhance certain enzyme activity, it can also have an inhibitory effect on other N-reducing enzymes. Several studies have noticed the preferential reduction of $\mathrm{NO}_{3}{ }^{-}$over $\mathrm{N}_{2} \mathrm{O}$ 
when $\mathrm{NO}_{3}{ }^{-}$is easily accessible as the solute species is a more energetically favorable terminal electron acceptor (Ruser et al., 2006; Swerts et al., 1996).

Ample carbon substrate availability has been shown to facilitate the reduction of $\mathrm{NO}_{3}{ }^{-}$to $\mathrm{NO}_{2}^{-}$, expediting this denitrification flux and potentially causing an accumulation of $\mathrm{NO}_{2}^{-}$(Kelso et al., 1999). Carbon substrates also stimulate respiration, reinforcing anoxic conditions and further promoting denitrifying conditions (Schlüter et al., 2018). For agricultural soils, optimal pH values for higher denitrification rates tend to lie around soil native $\mathrm{pH}$ values (Smith and Tiedje, 1979). Lower $\mathrm{pH}$ conditions have been demonstrated to inhibit nitrous oxide reductase, thereby shifting the denitrification end product under these conditions from dinitrogen $\left(\mathrm{N}_{2}\right)$ to $\mathrm{N}_{2} \mathrm{O}$ (Čuhel and Šimek, 2011; Liu et al., 2010). However, under high pH conditions nitrous oxide reductase is not inhibited resulting in the complete reduction of more $\mathrm{N}_{2} \mathrm{O}$ to $\mathrm{N}_{2}$.

Similar to nitrification, soil denitrification rates are largely tied to temperature with denitrification rates rising with rising temperatures (Braker et al., 2010; Elefsiniotis and Li, 2006; Saad and Conrad, 1993). Increases in denitrification rates are more significant at lower temperatures, especially close to $0^{\circ} \mathrm{C}$ where small shifts in temperature can cause dramatic increases in denitrification activity (Wertz et al., 2013). Denitrifier community composition and function may also shift with temperature, altering the denitrification pathway and which denitrification reaction is the flux limiting step, thereby affecting concentration ratios between denitrification substrates (Bremer et al., 2009; Saad and Conrad, 1993; Walker et al., 2008).

Soil moisture strongly affects diffusion and aeration, controlling whether denitrification is an important $\mathrm{N}$ transformation process and to the extent denitrification is carried out in a given 
soil matrix. As WFPS increases and aeration decreases, denitrification is favored over nitrification, becoming the dominant process and source of $\mathrm{N}_{2} \mathrm{O}$ at a threshold between $60-70 \%$ WFPS (Davidson, 1992). At higher WFPS, a greater fraction of gaseous $\mathrm{N}$ denitrification end products is emitted as $\mathrm{N}_{2}$ (Del Grosso et al., 2000). High rates of denitrification may even occur in soils with lower water contents if soil gas diffusivity is low and pore space is largely comprised by micropores. In these soils, $\mathrm{O}_{2}$ diffusion is limited and will not be able to meet microbial demand, causing denitrifying microbes to shift to utilizing $\mathrm{N}$ oxides as terminal electron acceptors (Skiba, 2008). For example, compaction due to tire traffic or tilling may engender these conditions in agricultural soils, which are already prone to N loss via denitrification (Torbert and Wood, 1992).

\subsubsection{Agricultural Soil Nitrogen Mineralization}

While fertilizer is considered the primary $\mathrm{N}$ source in agricultural systems leading to $\mathrm{N}$ loss, $\mathrm{N}$ mineralization may mobilize a significant amount of $\mathrm{N}$ present in soil (Jarvis et al., 1996). Soil properties, management, and climate are determining factors that control $\mathrm{N}$ mineralization (Benbi and Richter, 2002). Total $\mathrm{N}$ has been demonstrated to be both a poor and decent indicator of N mineralization depending on the soil type (Dessureault-Rompré et al., 2014; Miller et al., 2019; Vigil et al., 2002). Many studies have found SOM is the best predictor of N mineralization in soils with large SOM pools, but this method is not consistently accurate (Haynes, 2005; Ros, 2012). In low SOM content soils, mineralization rates are difficult to estimate based off SOM. Miller et al. (2019) found crop management histories could play an important role in mineralization rates as crops residues comprise a significant fraction of organic matter in low SOM soils. In general, mineralization rates increase with increasing temperature up until the enzymes necessary to carry out decomposition begin to denature (Dessureault-Rompré et al., 2010). Optimum soil $\mathrm{N}$ mineralization temperature occurs around $25-30^{\circ} \mathrm{C}$ and optimum moisture content 
occurs around 60-80\% WFPS (Guntiñas et al., 2012; Knoepp and Swank, 2002). Temperature is observed to be the primary control in most $\mathrm{N}$ mineralization rate studies with moisture content acting as a secondary control. However, in soil conditions where temperature is not limiting, moisture content acts as the primary controlling variable (Wong and Nortcliff, 1995).

Many factors influence agricultural soil $\mathrm{N}$ mineralization rates with certain soil and climate properties (e.g., SOM, temperature, agricultural management, etc.) heavily impacting net $\mathrm{N}$ mineralization rates. As FTCs inherently affect a number of these factors, they have been noted to alter $\mathrm{N}$ mineralization rates at least in the short-term (Matzner and Borken, 2008). Many studies have noted dramatic increases in $\mathrm{N}$ mineralization following soil thaw (DeLuca et al., 1992; Herrmann and Witter, 2002) while others have observed no significant changes in N mineralization (Groffman et al., 2001). Some studies have noted an increase in $\mathrm{N}$ mineralization following freezethaw but mineralization rates return to rates equal to or lower than those recorded from unfrozen soil following additional FTCs (Schimel and Clein, 1996). Improving our understanding of how FTC affects net $\mathrm{N}$ mineralization and interacts with other chemical and physical properties will contribute to site-specific $\mathrm{N}$ mineralization models and enhance $\mathrm{N}$ fertilizer management plans.

\subsection{Nutrient Management in Agroecosystems}

Nitrogen is a key limiting nutrient for crop growth in agricultural systems (Guignard et al., 2017). Anthropogenic $\mathrm{N}$ surface inputs have doubled the available $\mathrm{N}$ in terrestrial systems due to increasing agricultural activity (Galloway et al., 2008; Schlesinger, 2009; Vitousek et al., 1997). $\mathrm{N}$ is a limiting nutrient for plant growth and fertilizers have been utilized to alleviate this demand (Ågren et al., 2012). However, these agroecosystem N loads are unsustainable and have been demonstrated to contribute to global, regional, and local environmental problems including $\mathrm{N}_{2} \mathrm{O}$ 
emissions, eutrophication-driven hypoxia, and drinking water nitrate $\left(\mathrm{NO}_{3}{ }^{-}\right)$contamination (Power and Schepers, 1989; Reay et al., 2012; Smolders et al., 2010). These issues require that nutrient management strategies be developed to allow for efficient and balanced $\mathrm{N}$ application.

Controlled-release and nitrification-inhibited fertilizers are promising means of reducing fertilizer $\mathrm{N}$ pollution while improving $\mathrm{N}$ use efficiency, thereby providing an environmental and economic benefit over traditional fertilizers (Shaviv and Mikkelsen, 1993; Yang et al., 2016). Controlled release fertilizers are hydrophobic-coated granular fertilizers that slowly release encapsulated nutrients at rates controlled by the diffusion coefficient of the coating (Lubkowski and Grzmil, 2007). This slow release of nutrients prevents the supply from exceeding the intake capacity of the target crop. Nitrification inhibitors limit the conversion of $\mathrm{NH}_{4}^{+}$to $\mathrm{NO}_{2}^{-}$by inhibiting the ammonia monooxygenase enzyme (AMO) in Nitrosomonas bacteria (Hoeft, 1984; McCarty, 1999; Norton and Ouyang, 2019). Preserving $\mathrm{N}$ in the form of $\mathrm{NH}_{4}{ }^{+}$prevents the $\mathrm{N}$ from being converted to a more mobile species such as $\mathrm{NO}_{3}{ }^{-}$and $\mathrm{N}_{2} \mathrm{O}$ and increases the potential for the applied $\mathrm{N}$ to be assimilated by the plant root system.

While controlled-release fertilizers and nitrification inhibitors appear to be the most appropriate solution to meet modern agricultural demands while minimizing the detrimental effects of $\mathrm{N}$ fertilization, the resilience of these fertilizers technologies to expected changes in temperate climates has not received enough attention. Nitrification inhibitor effectiveness has been demonstrated to be affected by temperature, moisture, and organic matter conditions (Hatch et al., 2005; Irigoyen et al., 2003; Menéndez et al., 2012; Puttanna et al., 1999). Freeze-thaw cycling inherently causes stressful shifts in all of the environmental factors. The projected increase in FTC frequency necessitates that the performance of nitrification inhibitors be examined under freeze- 
thaw conditions. Experiment results would enhance agriculture soil $\mathrm{N}$ loss models and may indicate nutrient management strategies that recommend nitrification inhibitors should put forward alternative solutions to reduce $\mathrm{N}$ loss.

Research interest in the dramatic effects of FTCs on soil properties and soil nutrient pools has increased in recent years but several knowledge gaps still exist. Matzner and Borken (2008) noted that there is very little information on the interplay between freeze-thaw events and fertilizer nutrient dynamics in agricultural soils. Therefore, the question of how non-growing season nutrient leaching will be altered by FTCs in the context of climate change is necessary to study to accurately represent this flux in agricultural catchment models and refine fertilizer application best management practices in cold climate regions.

\subsection{Thesis Objectives}

The main objective of this thesis is to advance the mechanistic understanding of the effects of winter processes on nutrient dynamics in fertilized agricultural soils with specific focus on $\mathrm{N}$ cycling.

The specific objectives of Chapter 2 include:

1. Assess the effect of freezing and thawing cycles on $\mathrm{N}$ transformations in agricultural soils by comparing $\mathrm{N}$ leaching under the fertilized and unfertilized conditions.

2. Evaluate the transport dynamics of $\mathrm{Cl}^{-}$and $\mathrm{SO}_{4}{ }^{2-}$ through a soil column system under non-growing season climate conditions.

3. Create a model that defines the processes controlling soil $\mathrm{N}$ cycling under variable soil temperature, aeration, and moisture conditions. 
In Chapter 3 of this thesis, the specific objectives are to:

1. Investigate how freeze-thaw cycles affect nitrification inhibitor efficacy in fertilized agricultural soils.

2. Assess the influence of freeze-thaw cycling on net $\mathrm{N}$ mineralization rates of agricultural soils.

\subsection{Thesis Outline}

This thesis comprises four chapters that explore the interaction between freeze-thaw cycling and $\mathrm{N}$ fertilizer applied to agricultural soils. Chapter 1 introduces key concepts relating to climate change, winter soil processes, nutrient dynamics in soils, and agriculture fertilization practices, contextualizing the following chapters. Chapter 2 includes a co-authored manuscript which has been prepared for submission to Canadian Journal of Soil Science. The manuscript in Chapter 2 details a soil column experiment investigating the effects of freeze-thaw cycling on nutrient leaching from fertilized agricultural soil. I am first author on this co-authored manuscript. The formatting of manuscript figures, tables, equations, and sections have been updated for consistency with the overall thesis. Chapter 3 provides background on the mechanisms and benefits of nitrification inhibitors and describes a sacrificial soil batch experiment examining the effects of freeze-thaw cycling on nitrification inhibitor efficacy. Chapter 4 concludes by summarizing the experiment results, discussing the findings, and recommending future research based off knowledge gaps highlighted by the findings of Chapters 2 and 3. This conclusion is followed by a list of references and an Appendix for experimental data not included in Chapters 2 and 3. 


\title{
Impact of Winter Soil Processes on Nutrient Leaching in Cold Region Agroecosystems
}

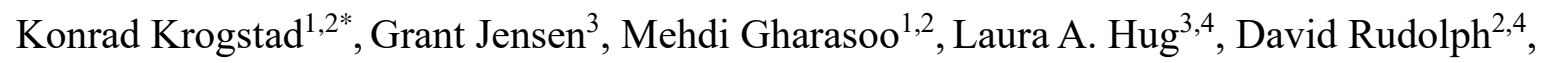 \\ Philippe Van Cappellen ${ }^{1,2,4}$, Fereidoun Rezanezhad ${ }^{1,2,4}$ \\ ${ }^{1}$ Ecohydrology Research Group, University of Waterloo, Waterloo, Ontario, Canada \\ ${ }^{2}$ Department of Earth and Environmental Sciences, University of Waterloo, Waterloo, Ontario, \\ Canada \\ ${ }^{3}$ Department of Biology, University of Waterloo, Waterloo, Ontario, Canada \\ ${ }^{4}$ Water Institute, University of Waterloo, Waterloo, Ontario, Canada \\ *Corresponding author: Konrad Krogstad \\ Ecohydrology Research Group, Department of Earth and Environmental Sciences, University of \\ Waterloo, 200 University Avenue West, Waterloo, Ontario, Canada N2L 3G1 \\ kjkrogstad@uwaterloo.ca \\ Phone: +1 (519) 888-4567, Ext. 31329
}

This chapter will be modified for submission to Canadian Journal of Soil Science. 


\section{Impact of Winter Soil Processes on Nutrient Leaching in Cold}

\section{Region Agroecosystems}

\subsection{Abstract}

High-latitude cold regions are warming more than twice as fast as the rest of the planet, with the greatest warming occurring during the winter. Warmer winters are associated with shorter periods of snow cover, resulting in more frequent and extensive soil freezing and thawing. Freeze-thaw cycles influence soil chemical, biological, and physical properties and any changes to winter soil processes may impact carbon and nutrients export from affected soils, possibly altering soil health and nearby water quality. These impacts are relevant for agricultural soils and practices in cold regions as they are critical in governing water flows and quality within agroecosystems. In this study, a soil column experiment was conducted to assess the leaching of nutrients from fertilized agricultural soil during the non-growing season. Four soil columns were exposed to a non-growing season temperature and precipitation model and fertilizer amendments were made to two of the columns to determine the efficacy of fall-applied fertilizers and compared to other two unfertilized control columns. Leachates from the soil columns were collected and analyzed for cations and anions. The experiment results showed that a transition from a freeze period to a thaw period resulted in significant loss of chloride $\left(\mathrm{Cl}^{-}\right)$, sulfate $\left(\mathrm{SO}_{4}{ }^{2-}\right)$ and nitrate $\left(\mathrm{NO}_{3}{ }^{-}\right)$. Even with low $\mathrm{NO}_{3}{ }^{-}$ concentrations in the applied artificial rainwater and fertilizer, high $\mathrm{NO}_{3}{ }^{-}$concentrations $(\sim 150 \mathrm{mg}$ $\left.\mathrm{L}^{-1}\right)$ were observed in fertilized column leachates. Simple plug flow reactor model results indicate the high $\mathrm{NO}_{3}{ }^{-}$leachates are found to be due to active nitrification occurring in the upper oxidized portion of the soil columns mimicking overwinter $\mathrm{NO}_{3}{ }^{-}$losses via nitrification in agricultural fields. The low $\mathrm{NO}_{3}{ }^{-}$leachates in unfertilized columns suggest that freeze-thaw cycling had little 
effect on $\mathrm{N}$ mineralization in soil. Findings from this study will ultimately be used to bolster winter soil biogeochemical models by elucidating nutrient fluxes over changing winter conditions to refine best management practices for fertilizer application.

Keywords: Winter soil processes, freeze-thaw cycles, agricultural soils, fertilizer application, nutrient leaching

\subsection{Introduction}

Soils are a key component of global carbon and nutrient cycles, constituting the largest terrestrial carbon reservoir and serving as an interface between the atmosphere, biosphere, hydrosphere, and lithosphere (Y. Zhou et al., 2019). Soil hydro-biogeochemical properties and processes control water filtration, flow regulation, erosion resistance, contaminant immobilization, and crop cultivation, as well as soil greenhouse gas (GHG) emissions and primary production (Keesstra et al., 2012; Knapen et al., 2007; Smith et al., 2015). However, these soil functions are dependent on climate and land use. In agroecosystems, climate warming is expected to alter global soil biogeochemical cycling, affecting carbon and nutrient transformation and retention capacity, and intense agricultural land use has caused declines in soil organic carbon while associated fertilizer application has resulted in increased soil GHG emissions, nutrient runoff and loss (Halvorson et al., 2014; Post and Kwon, 2000). Agricultural systems are also critical source areas for nutrient pollutants (e.g., nitrogen $(\mathrm{N})$ and phosphorus $(\mathrm{P})$ ) due to fertilizer use and have been the target of numerous management strategies (Sharpley et al., 2003). For instance, the no-till conservation techniques have been increasingly employed to mitigate nutrient loss due to erosion, but nutrient export via surface runoff, subsurface leaching, and volatilization allow for continued high nutrient export (Beach et al., 2018; King et al., 2017). 
In cold climate regions, as seasonal snow cover periods are shortened due to winter climate warming, soils are becoming more susceptible to freezing during the non-growing season (i.e., NGS: fall, winter, and spring) (Zhang, 2005; Hayashi et al., 2013; Zhang and Ma, 2018; Natali et al., 2019). During the shoulder NGS, diurnal temperature fluctuations will likely increase the occurrence of freeze-thaw cycles (FTCs) in soils lacking an insulating snowpack (Campbell et al., 2014; T. Watanabe et al., 2019). FTCs impact soil physical, hydrological and chemical properties and microbial populations (Henry, 2007). These changes in soil characteristics have been observed in many laboratory and field studies and been linked to changes in carbon and nutrient dynamics in FTC-affected soils (Campbell et al., 2010; Matzner and Borken, 2008; Song et al., 2017). Winter soil carbon and nutrient dynamics in colder regions have a significant impact on annual carbon and nutrient budgets (Matzner and Borken, 2008; Mikan et al., 2002; Monson et al., 2006). A number of studies have found that microbial processes may persist at subzero temperatures, which has implications for biogeochemical activities and nutrient stocks and species available for export during thaw periods (Elberling and Brandt, 2003; Groffman et al., 2009; Panikov et al., 2006; Wipf et al., 2015). In particular, $\mathrm{N}$ fertilizers have been demonstrated to be susceptible to nitrification at soil temperatures below freezing (Chantigny et al., 2019; Clark et al., 2009). This is of concern as tile drainage systems are prone to nitrate $\left(\mathrm{NO}_{3}^{-}\right)$loss during the non-growing season (NGS) due to excessive fertilizer application, nitrification, and lack of crop $\mathrm{NO}_{3}{ }^{-}$uptake, while controlled drainage systems can mitigate $\mathrm{NO}_{3}{ }^{-}$losses but may increase $\mathrm{N}_{2} \mathrm{O}$ emissions via denitrification (Kliewer and Gilliam, 1995; Lalonde et al., 1996; Saadat et al., 2018). As a consequence, agricultural $\mathrm{N}$ pools pose a water and atmospheric contamination threat (Almasri and Kaluarachchi, 2004; Mahvi et al., 2005). 
In agroecosystems, NGS studies examining nutrient loss have typically focused on how FTCs affect natural nutrient pools, but few have centered on how they impact fertilizer loss from agricultural soils. Our growing understanding of the NGS physical and biological processes require that fertilizer application practices (fertilizer source, rate, time, and place) in cold climate regions be reexamined to minimize nutrient loss during this dynamic period. For example, fall fertilizer application is a common agricultural practice performed out of convenience and under the assumption that the applied fertilizer will remain and be available to crops come the spring (Gentry et al., 2014; Romero et al., 2017). However, these nutrients are susceptible to overwinter losses, especially in cold climate regions (Chantigny et al., 2019; Ryan et al., 2000). Current nutrient management strategies like the $4 \mathrm{R}$ fertilization guidelines seek to provide a holistic approach to nutrient management, accounting for economic, environmental, and social outcomes of fertilizer use (Johnston and Bruulsema, 2014). The 4R nutrient stewardship guidelines (right source at the right rate, right time, and right place) acknowledge these overwinter losses, but climate changedriven changes to the severity and incidence rates of winter soil processes such as freeze-thaw cycling remain a prominent knowledge gap. Therefore, studies on winter processes targeting fertilizer retention in agricultural soil can inform nutrient management strategies, like the 4R fertilizer guidelines, to account for changing conditions in cold region agroecosystems.

In this study, a freeze-thaw soil column experiment was conducted using agricultural soil to explore the effects of winter soil processes on fertilizer loss under variable winter conditions. This was achieved by exposing soil columns to a winter and shoulder season air temperature and precipitation models to assess the leaching of nutrients from fertilized agricultural soil during the NGS. A pair of unfertilized control columns were also packed with the same soil and exposed to the same temperature conditions to determine the background nutrient leaching for comparison. 
The goal of the experiment was to better delineate the effect FTCs have on nutrient exports in agricultural soils by comparing nutrient leaching under the fertilized and unfertilized conditions. While our experiment did not include a non-FTC condition, several leachate samples were collected during the early portion of the experiment prior to the onset of freeze-thaw cycling that that are representative of leaching under non-FTC conditions. Our hypothesis was that the simulated FTCs would greatly enhance and alter nutrient leaching from fertilized agricultural soils and slightly enhance and alter nutrient leaching from unfertilized agricultural soils.

\subsection{Materials and Methods}

\subsubsection{Soil Collection and Properties}

The soil sample used for the experiments was collected from an agricultural field at the rare Charitable Reserve in Cambridge, Canada (latitude 43²2'39.80"N; longitude $\left.80^{\circ} 22^{\prime} 07.28^{\prime \prime} \mathrm{W}\right)$ in mid-October. This field had been cultivated in previous years but had not been cultivated for two years prior to soil sample collection. The soil was collected from the surface horizons $(0-18 \mathrm{~cm})$. The particle size distributions of the soil sample were determined using the pipette method (Gee and Bauder, 1986) and the analysis showed 32\%, 52\% and $16 \%$ of sand, silt

and clay contents, respectively, with textures ranging from silt loam to loam and a $\mathrm{pH}$ of 7.2. Total porosity and bulk density of soil sample were determined gravimetrically from the saturated mass, the oven-dried (at $105^{\circ} \mathrm{C}$ for 24 hours) mass and the original volume of the sample, following the method of Boelter (1972) and the bulk density and porosity were calculated to be $1.22 \mathrm{~g} \mathrm{~cm}^{-3}$ and 0.54 , respectively. 


\subsubsection{Experimental Freeze-thaw Soil Column System}

The entire experimental freeze-thaw soil column system consists of four columns (a schematic diagram of the column set-up is shown in Figure 2-1). The collected soil sample was sieved to $2 \mathrm{~mm}$, homogenized, and then four hard acrylic columns (inner diameter: $7.5 \mathrm{~cm}$, length: $60 \mathrm{~cm}$; Soil Measurement Systems, LLC, USA) were packed with $50 \mathrm{~cm}$ of soil. Each column was packed with a similar mass of soil $(\sim 2.5 \mathrm{~kg})$ and the columns were placed in an environmental chamber incubator (Percival I-41NL XC9) whose air temperature was controlled. The soil columns were initially saturated from the bottom with Milli-Q water and stored at $10^{\circ} \mathrm{C}$ for 5 days prior to experiment initiation. The soil column system was designed to simulate freeze-thaw cycles with realistic soil subsurface temperature gradients. A 150-watt band-heater $\left(120 \mathrm{~V}, 2 \mathrm{~W} / \mathrm{inch}^{2}\right.$, custommade by Gordo Sales Inc.) was placed surrounding the lower $40 \mathrm{~cm}$ of each column that maintained the temperature at $8^{\circ} \mathrm{C}$ in the lower portion of the soil, representative of southern Ontario's subsurface soil and groundwater temperatures (Conant, 2004; Funk et al., 1980), to simulate a realistic vertical soil subsurface temperature gradient. This allowed for the top $10 \mathrm{~cm}$ of soil above the band-heater to be exposed to fluctuating chamber air temperatures. As the air temperature drops below $0^{\circ} \mathrm{C}$, freezing occurs downwards from the surface of the soil. As the air temperature returns above $0^{\circ} \mathrm{C}$, the upper soil layer thaws. By pre-programming the air temperature cycle in the chamber, freeze-thaw cycles were induced in the soil columns (see 2.5). The top and bottom of the columns were closed with the acrylic end-caps sealed tightly by the O-rings inside of the end-caps. A filter membrane (Soil Measurement Systems, LLC, USA, bubbling pressure: 600 mbar) closed off the bottom of each column with a nylon mesh (Soil Measurement Systems, LLC, USA, bubbling pressure: $32 \mathrm{mbar}$ ) the top of filter membrane. For each column, three steel rods connected the acrylic top and bottom end-caps and were secured with bolts. The headspace 
of the soil columns was flushed with water-saturated air to minimize evaporative losses through the upper part of the columns. Time-series temperature data was recorded every 15 minutes during the experiment by six temperature sensors (DaqLink Fourier Systems Ltd., \#DBSA720) installed in one of the soil columns at depths of $+2.5,-3.5,-7,-15.5$, and $-33 \mathrm{~cm}$ relative to the soil surface, with one sensor in the chamber to monitor air temperature. Gravimetric soil water content was measured weekly using soil samples collected along the depth of the columns. Samples were dried at $105^{\circ} \mathrm{C}$ for 24 hours to determine dry soil weight. Gravimetric soil water content was determined by dividing the difference between wet and dry soil weights by the dry soil weight (see Table A1).

Unfertilized Columns

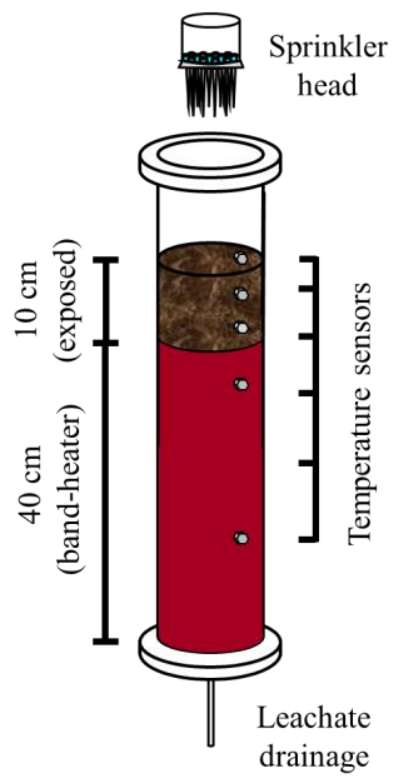

Fertilized Columns
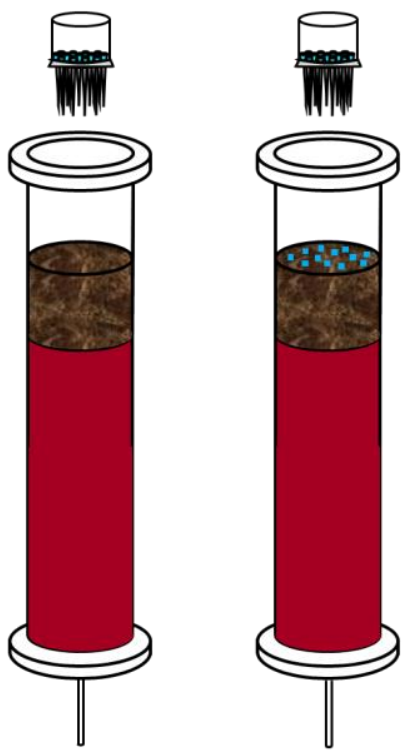

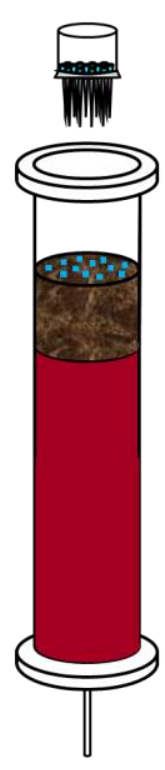

Model Column

Concept

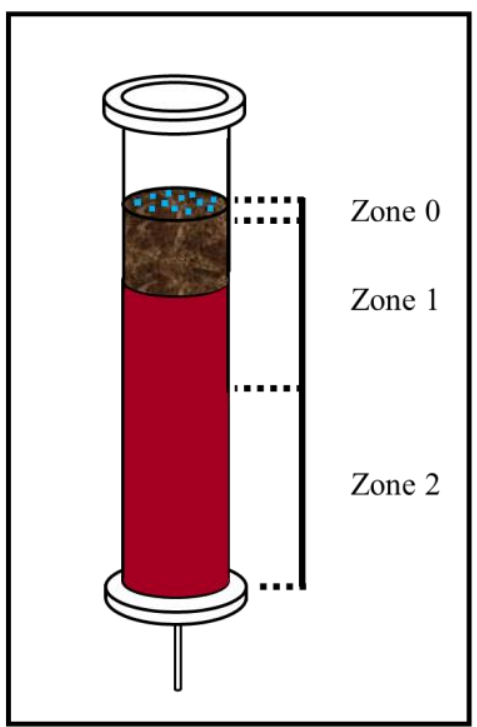

Figure 2-1: Schematic showing the two control columns (unfertilized) and two experimental columns (fertilized). Temperature sensors were installed at $+2.5,-3.5,-7,-15.5$, and $-33 \mathrm{~cm}$ relative to the soil surface in one of the control columns. The column on the right is showing the concept used for the simple plug flow reactor model with three zones (see 2.2.6). 


\subsubsection{Environmental Chamber Temperature and Precipitation Regimes}

The soil columns were exposed to a 55-day NGS air temperature and precipitation weather sequences (Figure 2-2), representative of winter and shoulder seasonal climate in southern Ontario (data retrieved from Environment and Climate Change Canada database). Daily air temperatures (incubator temperature) fluctuated by about 8 to $10^{\circ} \mathrm{C}$ with daily low temperatures occurring between 0:00 and 12:00 and daily high temperatures occurring between 12:00 and 24:00. The incubator took approximately 2 hours to warm or cool following a temperature transition. During the coldest period of the NGS temperature model, a one-day and three-day thaw (occurring around day 30 and 32 of the experiment, respectively) were included to examine the effects of a simulated mid-winter thaw (see Figure 2-2). A precipitation model was simulated by adding 55 to $90 \mathrm{ml}$ of artificial rainwater (2-3 times per week, see Figure 2-2) to the top of each soil column via a sprinkler. 

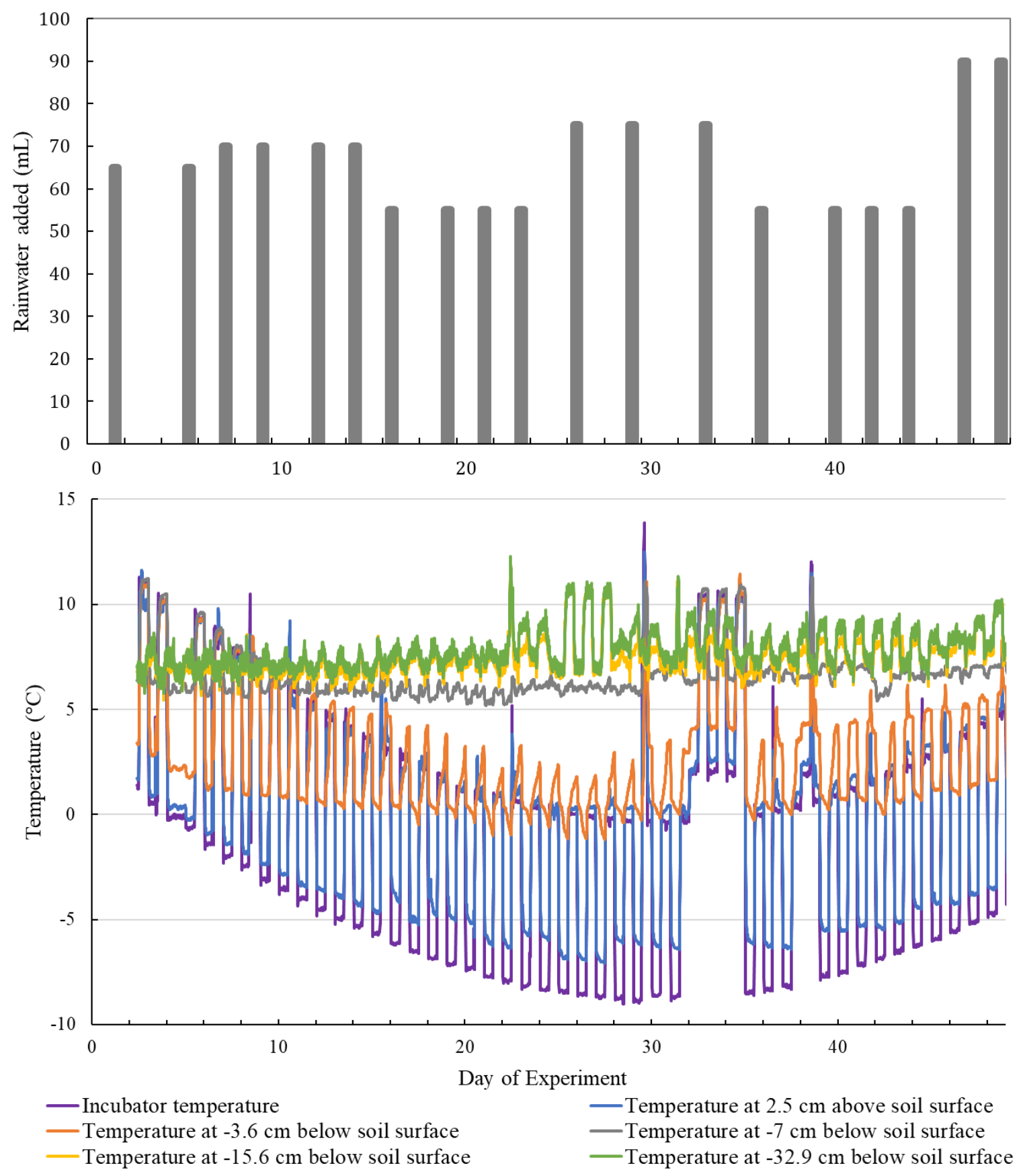

Figure 2-2: The top graph shows total applied volume of artificial rainwater over the course of the experiment. The bottom graph shows air temperature and soil temperature at various depths over the course of the experiment. Soil temperatures were measured at different depths below the soil surface in one of the columns and treated as representative for all columns. 


\subsubsection{Fertilizer Amendments and Artificial Rainwater}

The 15-30-15 NPK Miracle-Gro was used as fertilizer amendments for the experiment. This fertilizer was selected for its solubility to leach through the experimental columns. $1 \mathrm{~g}$ of the fertilizer was ground up for each column and evenly distributed on top of the duplicate fertilized experimental soil columns while the duplicate control columns were left unfertilized (Figure 2-3). According to the NPK label, an estimated $150 \mathrm{mg}$ of elemental nitrogen was then applied to each fertilized column. Artificial rainwater was prepared with a chemical compositions containing $\mathrm{Cl}^{-}$ (0.25 mg L $\left.{ }^{-1}\right), \mathrm{SO}_{4}{ }^{2-}\left(2.2 \mathrm{mg} \mathrm{L}^{-1}\right), \mathrm{NO}_{3}{ }^{-}\left(2.6 \mathrm{mg} \mathrm{L}^{-1}\right), \mathrm{Na}^{+}\left(0.10 \mathrm{mg} \mathrm{L}^{-1}\right), \mathrm{Ca}^{2+}\left(0.48 \mathrm{mg} \mathrm{L}^{-1}\right), \mathrm{Mg}^{2+}$ (0.08 $\left.\mathrm{m} \mathrm{L} \mathrm{L}^{-1}\right)$, and $\mathrm{K}^{+}\left(0.05 \mathrm{mg} \mathrm{L}^{-1}\right)$, representative of southern Ontario's rainwater compositions ("Major Ions", 2018). A solution consisting of the mass of fertilizer applied to each column and a volume of Milli-Q water equivalent to the volume of total applied rainwater to each column (1.435 L) was prepared and the concentrations of selected anions were analyzed using ion chromatography (see 2.6) with concentrations of $10.7,0.2$, and $35 \mathrm{mg} \mathrm{L}^{-1}$ for chloride $\left(\mathrm{Cl}^{-}\right)$, sulfate $\left(\mathrm{SO}_{4}{ }^{2-}\right)$, and phosphate $\left(\mathrm{PO}_{4}{ }^{3-}\right)$, respectively, while concentrations of $\mathrm{NO}_{2}{ }^{-}$and $\mathrm{NO}_{3}{ }^{-}$were below the detection limits.

\subsubsection{Leachate Sampling and Analytical Methods}

Leachate pore water samples were collected from the bottoms of the four columns when there was sufficient volume for chemical analysis, usually 1 day following rainwater applications. Leachate samples were collected into $100 \mathrm{ml}$ plastic vial and $1 \mathrm{ml}$ of the samples were immediately used for $\mathrm{pH}$ and electrical conductivity (EC) analysis using handheld meters (LAQUAtwin meters, model Horiba B-213; see Figure A-2). One ml of leachate samples was filtered through a $0.2 \mu \mathrm{m}$ membrane filter (Thermo Scientific Polysulfone filter) and was analyzed for major anions 
including $\mathrm{Cl}^{-}, \mathrm{NO}_{3}{ }^{-}, \mathrm{PO}_{4}{ }^{3-}$, and $\mathrm{SO}_{4}{ }^{2-}$ using ion chromatography (IC, Dionex ICS-5000 with a capillary IonPac ${ }^{\circledR}$ AS18 column; $\pm 3.0 \%$ error and $\pm 1.6 \%$ precision).

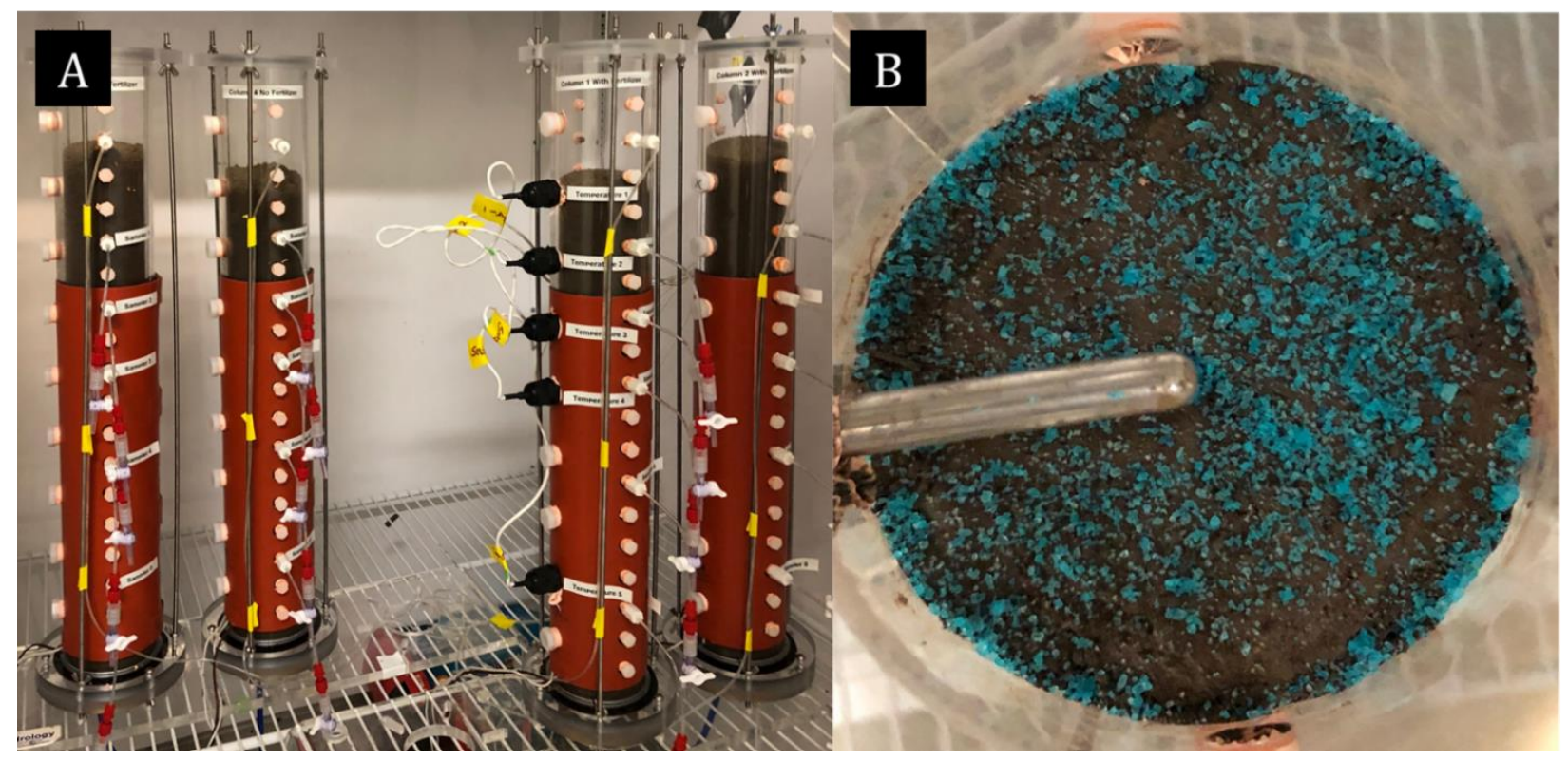

Figure 2-3: Photos of the soil column setup (A) and fertilizer applied on soil surface in fertilized columns (B).

\subsubsection{Model Description}

For the modeling of the $\mathrm{N}$ transformation in the fertilized soil columns, we used a simple plug flow reactor model describing chemical reactions in a continuous, connected, and flowing system of cylindrical geometries (shown as 3 separate zones in Figure 2-1). In this model simulation, urea is considered to be placed on the top few centimeters of the column (Zone 0) where it is hydrolysed to an unstable carbamic acid that quickly breaks down to carbon dioxide $\left(\mathrm{CO}_{2}\right)$ and ammonia gas $\left(\mathrm{NH}_{3}\right)$ and the latter reacts with water to form ammonium $\left(\mathrm{NH}_{4}^{+}\right)$. This chain of reactions occurs only at Zone 0 and is described by the following reaction: 


$$
\left(\mathrm{NH}_{4}^{+}\right)_{2} \mathrm{CO} \stackrel{k_{1}}{\rightarrow} \mathrm{NH}_{4}^{+}
$$

where $k_{1}\left[T^{-1}\right]$ is the rate constant for urea hydrolysis and dissolution of $\mathrm{NH}_{3}$ in water. At Zone 1 , where the oxygen can penetrate to this zone, the $\mathrm{NH}_{4}{ }^{+}$is oxidized to nitrite $\left(\mathrm{NO}_{2}^{-}\right)$:

$$
\mathrm{NH}_{4}^{+} \stackrel{k_{2}}{\rightarrow} \mathrm{NO}_{2}^{-}
$$

where $k_{2}\left[T^{-1}\right]$ is the rate constant for oxidation of ammonia. In presence of oxygen $\left(\mathrm{O}_{2}\right), \mathrm{NO}_{2}{ }^{-}$ further oxidized to $\mathrm{NO}_{3}{ }^{-}$as follows:

$$
\mathrm{NO}_{2}^{-} \stackrel{k_{3}}{\rightarrow} \mathrm{NO}_{3}^{-}
$$

where $k_{3}\left[T^{-1}\right]$ is the rate constant for nitrification. Zone 2 is assumed to be in anoxic condition and none of the above reactions can occur in Zone 2. In this zone, denitrification is considered as the main catabolic reaction:

$$
\mathrm{NO}_{3}^{-} \stackrel{k_{4}}{\rightarrow} 0.5 \mathrm{~N}_{2}
$$

where $k_{4}\left[T^{-1}\right]$ is the rate constant for denitrification. For a simple mass balance for the zones in the manner that the outlet from previous zone is the inlet of the next, combining with the above mentioned reactions, the following system of ordinary differential equations are considered (similar to Ehrl et al. (2018), Gharasoo et al. (2019), Marozava et al., (2019)):

$$
\frac{d\left[\mathrm{NH}_{4}^{+}\right]_{0}}{d t}=+k_{1}\left[\left(\mathrm{NH}_{2}\right)_{2} \mathrm{CO}\right]_{0}-r D_{0}\left[N H_{4}^{+}\right]_{0}
$$




$$
\begin{aligned}
& \frac{d\left[\left(\mathrm{NH}_{2}\right)_{2} \mathrm{CO}\right]_{0}}{d t}=-k_{1}\left[\left(\mathrm{NH}_{2}\right)_{2} \mathrm{CO}\right]_{0} \\
& \frac{d\left[N H_{4}^{+}\right]_{1}}{d t}=-k_{2}\left[N H_{4}^{+}\right]_{1}+r D_{1}\left(\left[N H_{4}^{+}\right]_{0}-\left[N H_{4}^{+}\right]_{1}\right) \\
& \frac{d\left[N O_{2}^{-}\right]_{1}}{d t}=+k_{2}\left[N H_{4}^{+}\right]_{1}-k_{3}\left[N O_{2}^{-}\right]_{1}-r D_{1}\left[N O_{2}^{-}\right]_{1} \\
& \frac{d\left[N O_{3}^{-}\right]_{1}}{d t}=+k_{3}\left[N O_{2}^{-}\right]_{1}-r D_{1}\left[N O_{3}^{-}\right]_{1} \\
& \frac{d\left[\mathrm{NO}_{3}^{-}\right]_{2}}{d t}=-k_{4}\left[N \mathrm{O}_{3}^{-}\right]_{2}+r D_{2}\left(\left[N \mathrm{~N}_{3}^{-}\right]_{1}-\left[N \mathrm{O}_{3}^{-}\right]_{2}\right) \\
& \frac{d\left[N O_{2}^{-}\right]_{2}}{d t}=+r D_{2}\left(\left[N O_{2}^{-}\right]_{1}-\left[N O_{2}^{-}\right]_{2}\right) \\
& \frac{d\left[N H_{4}^{+}\right]_{2}}{d t}=+r D_{2}\left(\left[N H_{4}^{+}\right]_{1}-\left[N H_{4}^{+}\right]_{2}\right) \\
& \frac{d\left[N_{2}\right]_{2}}{d t}=+k_{4}\left[N O_{3}^{-}\right]_{2}
\end{aligned}
$$

where $r D\left[T^{-1}\right]$ is the dilution rate to the zones 0,1 , and 2 , respectively and calculated as the ratio of input rainwater solution to the volume of each zone. The superscripts of the chemical concentrations and dilution rates refer to the entity value at each specific zone. Temperature sensitivities are simulated by allowing the first-order rate constants $\left(k_{1}, \ldots, k_{4}\right)$ to vary according 
to the Arrhenius function $k_{1}=k 0_{1} \exp \left(-E_{a i} / R T\right)$, where $k 0_{1}$ is the pre-exponential factor for reactions $i=1$ to $4, R$ is the universal gas constant, $E_{a i}$ is the reaction activation energy, and $T$ is temperature in Kelvin. Parameter values were determined from the soil column measurements or obtained from the literature as listed in Table A-2. The model run lasted 60 days and the fitting procedure was performed by ReKinSim (Gharasoo et al., 2017).

Table 2-1: List of parameters values used for model simulation and estimated parameters from the optimization of Equations 5 to the measured data. Reaction energies for the reactions 2, 3, and 4 were obtained from McKenney et al., 1984; Ambus, 1993; Saad and Conrad, 1993; and Maag et al., 1997.

Parameter values derived from measurements, calculations or literature values soil effective porosity $(\phi) \quad 0.30$ length of column $\quad 60 \mathrm{~cm}$ inner radius of column $\quad 3.75 \mathrm{~cm}$ total rain volume $1435 \mathrm{ml}$ rate of rain at inlet $\quad 23.9 \mathrm{ml} \mathrm{day}^{-1}$ volume of Zone 0 volumes of Zones 1 and $2 \quad 1215 \mathrm{ml}$ dilution rate of Zone $0\left(r D_{0}\right) \quad 0.108$ day $^{-1}$ dilution rate of Zones 1 and $2\left(r D_{1}\right.$ and $\left.r D_{2}\right) \quad 0.019$ day $^{-1}$ activation energy of reaction $2\left(E_{a 2}\right) \quad 55 \pm 10 \mathrm{~kJ} \mathrm{~mol}^{-1}$ activation energy of reaction $3\left(E_{a 3}\right) \quad 58 \pm 21 \mathrm{~kJ} \mathrm{~mol}^{-1}$ activation energy of reaction $4\left(E_{a 4}\right) \quad 60 \pm 11 \mathrm{~kJ} \mathrm{~mol}^{-1}$ universal gas constant $(R) \quad 8.314 \mathrm{~J} \mathrm{~mol}^{-1} \mathrm{~K}^{-1}$

Parameter values estimated by the model fit in this study rate constant of reaction $1\left(k_{1}\right)$ pre-exponential factor of reaction $2\left(k 0_{2}\right) \quad 6.4 \times 10^{10}$ day $^{-1}$ pre-exponential factor of reaction $3\left(k 0_{3}\right) \quad 4.7 \times 10^{11}$ day $^{-1}$ pre-exponential factor of reaction $4\left(k_{4}\right) \quad 9.3 \times 10^{8}$ day $^{-1}$

\subsection{Results}

\subsubsection{Temperature and Moisture Regimes in the Soil Columns}

The environmental chamber air temperature regularly fluctuated above and below zero during the beginning and end of the experiment (Figure 2-2). Air temperatures remained largely below $0^{\circ} \mathrm{C}$ during the middle of the experiment, except during the simulated midwinter thaws. The near 
surface temperature sensor $(-3.6 \mathrm{~cm}$ below soil surface) recorded temperatures regularly fluctuating above and below $0^{\circ} \mathrm{C}$ between Days 16 to 29 , but otherwise all recorded temperatures were above $0^{\circ} \mathrm{C}$. The near surface soil temperatures during the simulated midwinter thaws, following the coldest portion of the experiment, were comparable to temperatures recorded at the beginning and end of the experiment. Soil temperatures at depth below $-7 \mathrm{~cm}$ remained relatively stable throughout the experiment as deeper sections of the soil columns were buffered by the bandheater warming. Column moisture contents did not vary much by depth over the course of the experiment (see Table A-1). The average water filled pore space was $50.1 \%$ with a SD of $\pm 7.2 \%$.

\subsubsection{Soil Column Leachates}

The $\mathrm{pH}$ values varied from 6.5 to 8.5 in unfertilized column leachates and from 7 to 8.5 in fertilized column leachates. The EC varied from 0.1 to 170 and $200 \mu \mathrm{S} / \mathrm{cm}$ in unfertilized and fertilized columns, respectively. The concentrations of $\mathrm{PO}_{4}{ }^{3-}$ in both unfertilized and fertilized column leachates were not detected. $\mathrm{Cl}^{-}$concentrations in the unfertilized column leachates remained low $\left(<5 \mathrm{mg} \mathrm{L}^{-1}\right)$ throughout the duration of the experiment (Figure 2-4). For the fertilized columns, leachate $\mathrm{Cl}^{-}$concentrations were initially low but increased around Day 15 . This increase continued until the simulated midwinter thaw at Day 30, where the leachate $\mathrm{Cl}^{-}$concentration peaked at 266 and $194 \mathrm{mg} \mathrm{L}^{-1}$ in duplicate fertilized soil columns (Figure 2-4). Following the first mid-winter thaw (Day 30), leachate $\mathrm{Cl}^{-}$concentrations declined until the end of the experiment, reaching concentrations comparable to the concentrations in unfertilized columns. 


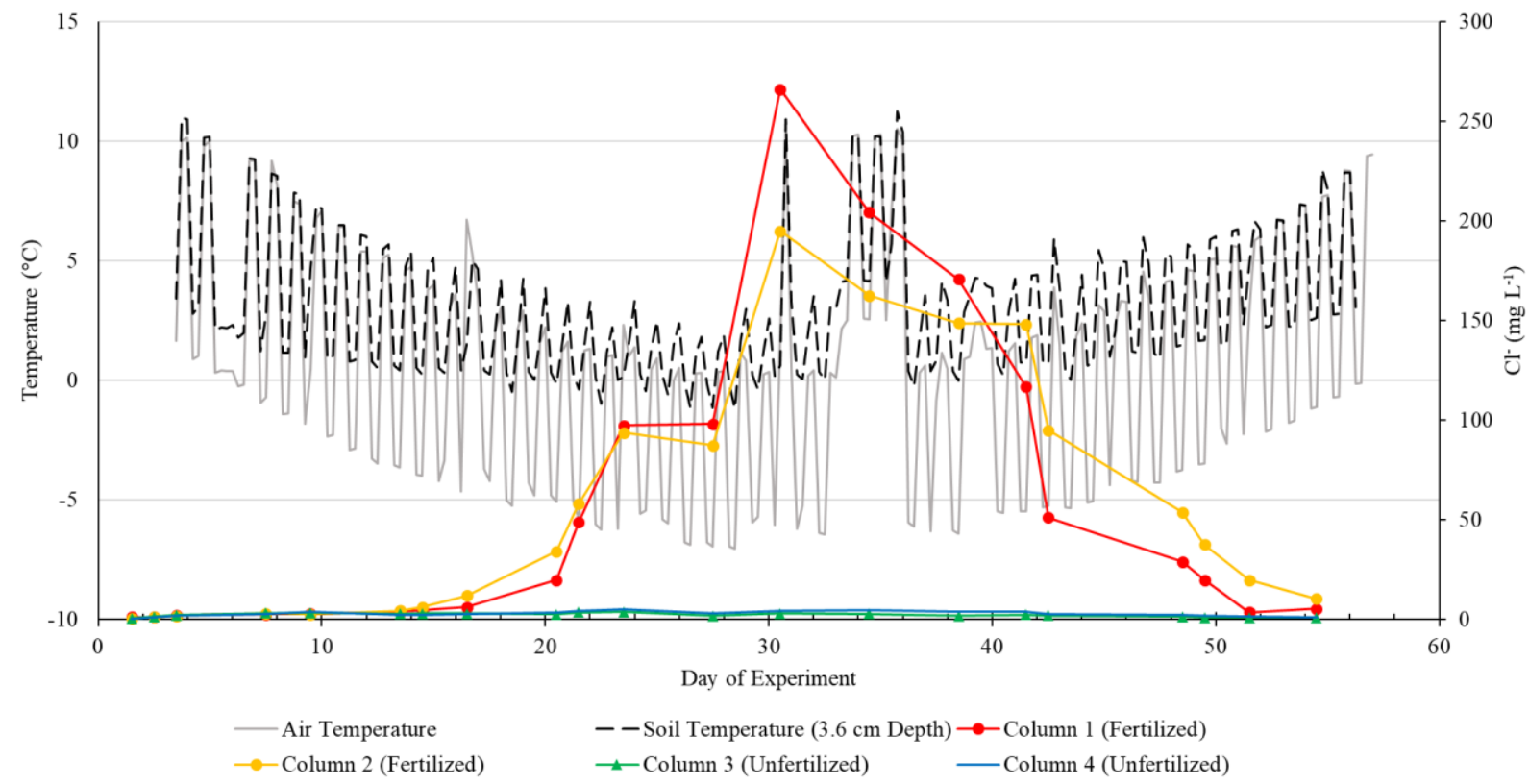

Figure 2-4: Temperature and leachate $\mathrm{Cl}^{-}$concentrations versus time for fertilized and unfertilized columns.

Leachate $\mathrm{SO}_{4}{ }^{2-}$ concentrations for the unfertilized and fertilized columns were low at the beginning of the experiment $\left(\sim 2 \mathrm{mg} \mathrm{L}^{-1}\right)$ and were comparable to the $\mathrm{SO}_{4}{ }^{2-}$ concentration in the artificial rainwater (2.2 $\left.\mathrm{mg} \mathrm{L}^{-1}\right)$ (Figure 2-5). Around Day 20 of the experiment, leachate $\mathrm{SO}_{4}{ }^{2-}$ concentrations for the fertilized columns began to increase but decreased once daily high and low soil temperatures remained below $0^{\circ} \mathrm{C}$. Following the one-day thaw (Day $\sim 30$ ), leachate $\mathrm{SO}_{4}{ }^{2-}$ concentrations for the fertilized columns drastically increased, peaking around 10 to $12 \mathrm{mg} \mathrm{L}^{-1}$ but declined after Day 40 until the end of the experiment. $\mathrm{NO}_{3}{ }^{-}$concentrations in the unfertilized soil column leachates remained low throughout the duration of the experiment $\left(<40 \mathrm{mg} \mathrm{L}^{-1}\right)$ (Figure 26). However, $\mathrm{NO}_{3}{ }^{-}$concentrations in the fertilized column leachates gradually increased from the onset of the experiment until Day $\sim 25$, at which point these concentrations decreased to 22.7 and $9.5 \mathrm{mg} \mathrm{L}^{-1}$ in duplicate columns. Following this decrease, $\mathrm{NO}_{3}{ }^{-}$concentrations in the fertilized column leachates increased for the remainder of the experiment, reaching peaks of 150 to $160 \mathrm{mg}$ $\mathrm{L}^{-1}$ for the last collected leachate samples. 


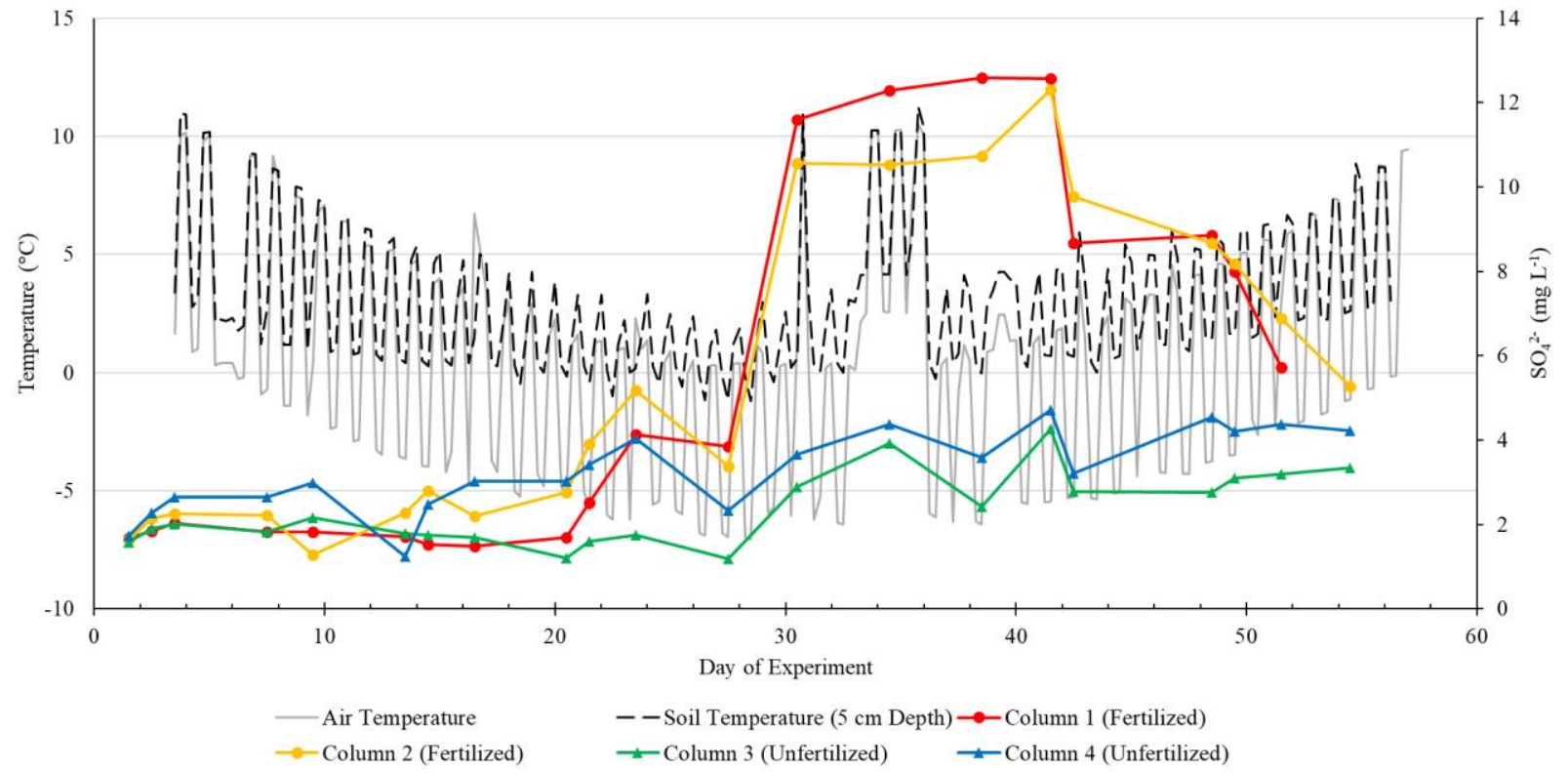

Figure 2-5: Temperature and leachate $\mathrm{SO}_{4}{ }^{2-}$ concentrations versus time for fertilized and unfertilized columns.

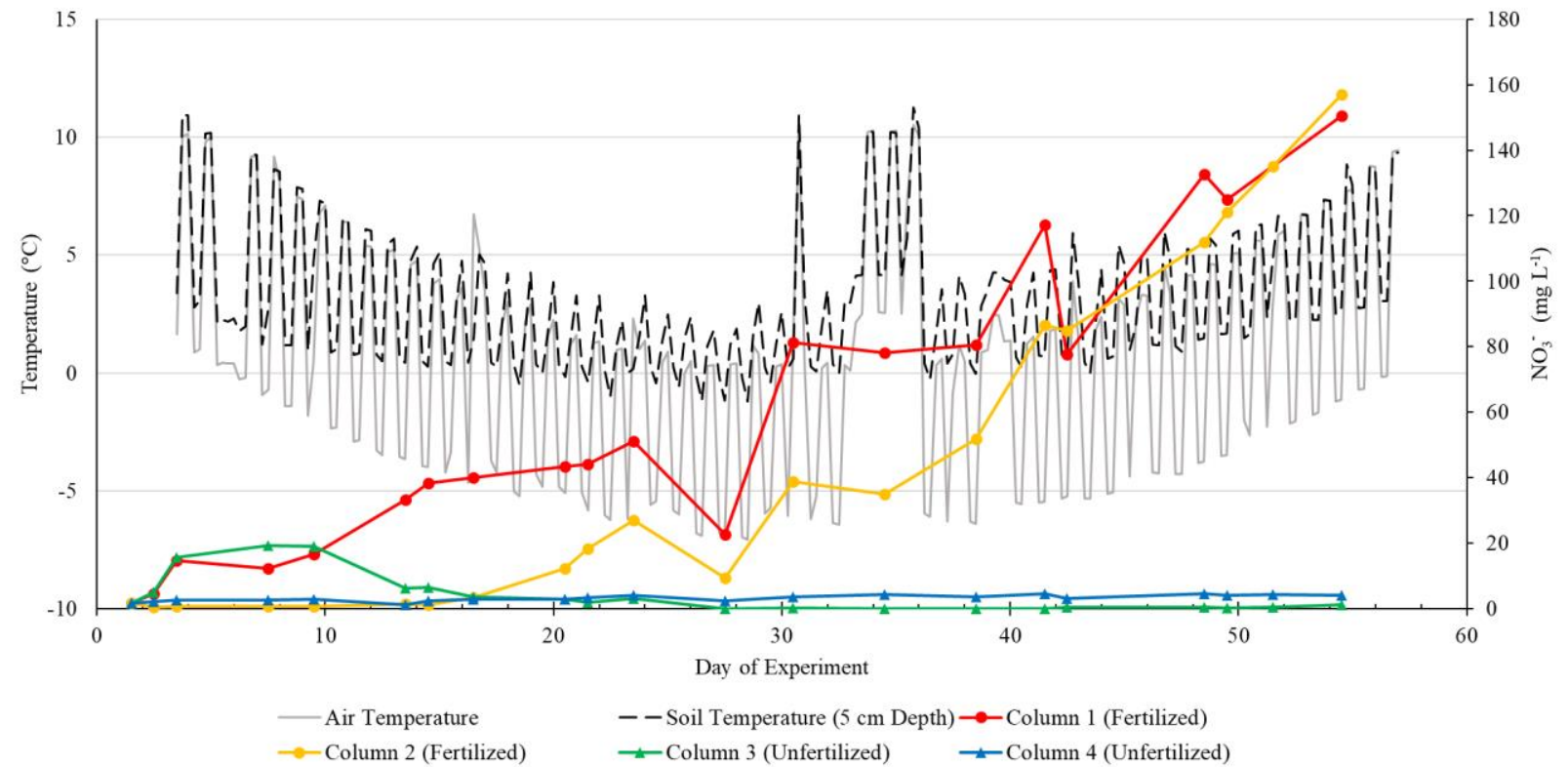

Figure 2-6: Temperature and leachate $\mathrm{NO}_{3}{ }^{-}$concentrations versus time for fertilized and unfertilized columns. 


\subsubsection{Modeling Results}

The calculated rate constants of $k_{1}, k_{2}, k_{3}$, and $k_{4}$ for the reactions 1 to 4 were as $k_{1}=0.15$; $1.22<k_{2}<6.77 ; 2.33<k_{3}<14.2$; and $0.002<k_{4}<0.012$ day $^{-1}$ (Table 1). These rate constants were calculated according to the Arrhenius equation and using the approximate range of temperatures in the column experiment $\left(-5\right.$ to $\left.15^{\circ} \mathrm{C}\right)$. Calculation of the Damköhler ratio, to compare the rate of reactions against the dilution rates $(r D i)$ in their respective zone, showed that the reaction rates are up to 3 orders of magnitude greater than the dilution rates, meaning that the flow resident times are slow enough to allow more than $90 \%$ conversion of the substrates. Only denitrification rates in Zone 2 are slightly lower than dilution rates, which seems to play a minor role in the final observations of leachate $\mathrm{NO}_{3}{ }^{-}$.

The model fit of the reactions to the measured $\mathrm{NO}_{3}{ }^{-}$in the fertilized soil columns and simulation of other $\mathrm{N}$ species concentrations in the three zones 0,1 and 2 show a strong fit to the data (Figure 2-7). The modeled $\mathrm{NH}_{4}{ }^{+}$concentrations in Zone 0 showed an increase up to 1,000 $\mathrm{mg}$ $\mathrm{L}^{-1}$ around Day 10 and then declined, as the urea is hydrolyzed in the first 20 days after applying the fertilizer. $\mathrm{NH}_{4}{ }^{+}$and $\mathrm{NO}_{2}{ }^{-}$concentrations in Zone 1 mirrored the $\mathrm{NH}_{4}{ }^{+}$concentration curve in Zone 0 but attained much lower peak concentrations $\left(\sim 10 \mathrm{mg} \mathrm{L}^{-1}\right) . \mathrm{NO}_{3}{ }^{-}$concentrations were highest in Zone 1 reaching a maximum of $\sim 250 \mathrm{mg} \mathrm{L}^{-1}$, as the model assumes nitrification is dominant in this zone but declined around Day 35 as $\mathrm{NH}_{4}{ }^{+}$input into Zone 1 begins to diminish. In Zone $2 \mathrm{NO}_{3}{ }^{-}$concentrations were tempered by reducing conditions that favor denitrification, peaking at $\sim 130 \mathrm{mg} \mathrm{L}^{-1}$ by the end of the model simulation. The $\mathrm{N}_{2}$ concentrations in Zone 2 increased for the entirety of the model and leveled off to a maximum concentration of $10 \mathrm{mg} \mathrm{L}^{-1}$ at the end of model simulation (see Figure 2-7). 


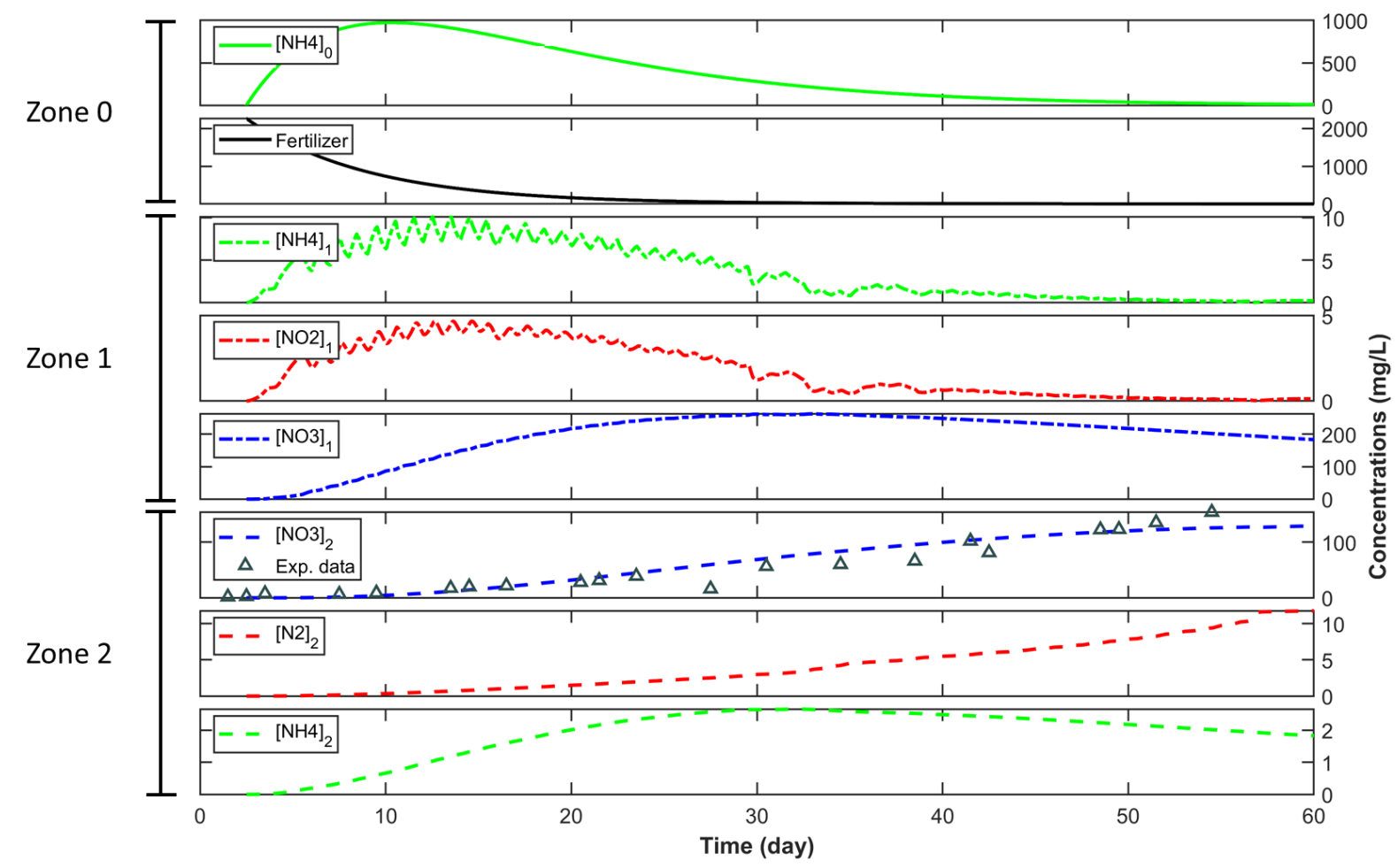

Figure 2-7: Model fit of reactions to the averaged $\mathrm{NO}_{3}{ }^{-}$concentrations measured in the fertilized soil columns and simulation of other $\mathrm{N}$ transformation processes in three zones 0,1 and 2 used for the simple plug flow reactor model. A list of parameters and their estimated values are presented in Table 1.

\subsection{Discussion}

\subsubsection{Impact of Winter Processes on Chloride and Sulfate Leachates}

Of the analytes examined in the leachate samples, the patterns of $\mathrm{Cl}^{-}, \mathrm{SO}_{4}{ }^{2-}$, and $\mathrm{NO}_{3}{ }^{-}$ concentrations differed greatly between the fertilized and unfertilized columns. $\mathrm{As} \mathrm{Cl}^{-}$is a relatively non-reactive ion that does not easily adsorb or react to the soil matrix, it serves as a tracer for the fertilizer front progressing through the fertilized soil columns (White and Broadley, 2001). If all applied fertilizer were incorporated into the applied rainwater solution, the effective average $\mathrm{Cl}^{-}$concentration would be $\sim 90 \mathrm{mg} \mathrm{L}{ }^{-1}$. However, most of the applied fertilizer was likely dissolved in the first several rainwater applications, forming a concentrated $\mathrm{Cl}^{-}$front, and the 
observed peak at Day 30 represents the breakthrough of this front and is an indicator of the dissolved fertilizer passing through the fertilized soil columns.

Similarly, if all applied fertilizer were incorporated into the applied rainwater solution, the effective average $\mathrm{SO}_{4}{ }^{2-}$ concentration would be $\sim 4.3 \mathrm{mg} \mathrm{L}^{-1}$. Thus, the observed $\mathrm{SO}_{4}{ }^{2-}$ peaks in the fertilized column leachates (Figure 2-5) likely represents the breakthrough of a solution front concentrated in $\mathrm{SO}_{4}{ }^{2-}$ relative to the background $\mathrm{SO}_{4}{ }^{2-}$ concentration in the artificial rainwater that can be attributed to the applied fertilizer. The decrease in $\mathrm{SO}_{4}{ }^{2-}$ concentrations during the frozen period (Days 24 to 28) may be due to the formation of an ice barrier at the soil surface, creating anaerobic conditions in the soil subsurface and facilitating $\mathrm{SO}_{4}{ }^{2-}$ reduction. However, Sawicka $e t$ al. (2010) noted that the freezing process is detrimental to sulfate-reducing bacteria and their activity remains limited until they are reactivated during the thaw. This would imply that the lower $\mathrm{SO}_{4}{ }^{2-}$ concentrations observed during the freezing period of the experiment are likely a result of transport dynamics and not microbial processes.

\subsubsection{Impact of Winter Processes on Nitrate Leachates}

Low measured $\mathrm{NO}_{3}{ }^{-}$concentration in the artificial rainwater and applied fertilizer suggest that the increase of $\mathrm{NO}_{3}{ }^{-}$in the fertilized column leachates over the entirety of the experiment (Figure 2-6) is due to nitrification processes, especially following the simulated mid-winter thaw. Matzner and Borken (2008) reported that soil freezing can induce $\mathrm{NO}_{3}{ }^{-}$leaching in their field nutrient leaching freeze-thaw experiments. However, Henry et al. (2007) stated that while soil mesocosm experiments have generally shown increased potential for nutrient leaching following freeze-thaw events, the temperature fluctuation ranges utilized in these experiments are typically much larger $\left(6\right.$ to $\left.10^{\circ} \mathrm{C}\right)$ than those experienced in in situ soils $\left(1\right.$ to $\left.2^{\circ} \mathrm{C}\right)$. The soil columns in this study were subjected to $\sim 10^{\circ} \mathrm{C}$ air temperature fluctuations, which only induced moderate soil 
temperature fluctuations $\left(2.5\right.$ to $\left.7^{\circ} \mathrm{C}\right)$. As unfertilized $\mathrm{NO}_{3}{ }^{-}$leachate concentrations did not increase following the onset of moderate FTCs during the mid-period of the experiment, our results appear to agree with previous studies that found FTCs had a negligible effect on overall $\mathrm{N}$ mineralization (Hentschel et al., 2008; Larsen et al., 2002), assuming inorganic $\mathrm{N}$ generated through mineralization would subsequently be nitrified to $\mathrm{NO}_{3}^{-}$. However, low $\mathrm{NO}_{3}^{-}$leachate concentrations in the unfertilized columns could be a result of the relatively low total $\mathrm{N}$ content in the soil from the sampling site $\left(1.6 \mathrm{~g} \mathrm{~kg}^{-1}\right)$ and the moderate intensity of the freezing temperatures applied in this experiment, as several previous studies have found that an increase in $\mathrm{N}$ mineralization can occur at colder freezing temperatures (Jiang et al., 2018; W. Zhou et al., 2011).

In a multi-site field freeze-thaw $\mathrm{N}$ loss study, Chantigny et al. (2019) found that artificial $\mathrm{N}$ fertilizers are susceptible to overwinter $\mathrm{NO}_{3}{ }^{-}$losses via nitrification, especially compared to organic $\mathrm{N}$ fertilizers, as organic fertilizers naturally included a carbon source to facilitate $\mathrm{N}$ immobilization. Similarly, in a soil jar batch experiment, Clark et al., (2009) determined that low temperature $\left(-2\right.$ to $\left.2^{\circ} \mathrm{C}\right)$ nitrification can lead to $\mathrm{NO}_{3}{ }^{-}$accumulation or loss that is not mitigated by $\mathrm{N}$ immobilization. While substantial $\mathrm{NO}_{3}{ }^{-}$leaching was observed from the fertilized columns following a one-day thaw (Day $~ 30$ ), leachate $\mathrm{NO}_{3}{ }^{-}$concentrations continued to increase for the remainder of the experiment despite warmer temperatures, suggesting that $\mathrm{NO}_{3}{ }^{-}$immobilization mechanisms did not resume or were not potent enough to stymie $\mathrm{NO}_{3}{ }^{-}$leaching.

\subsubsection{Modeling Nitrogen Transformations and Losses}

The increase of modeled $\mathrm{NH}_{4}{ }^{+}$in Zone 0 (Figure 2-7) is the result of rapid urea hydrolysis from the applied fertilizer. The transient $\mathrm{NH}_{4}{ }^{+}$and $\mathrm{NO}_{2}{ }^{-}$concentrations in Zone 1 were generated and subsequently consumed by the active nitrification occurring in this zone. The oscillating nature of the $\mathrm{NH}_{4}{ }^{+}$and $\mathrm{NO}_{2}{ }^{-}$concentrations shows the sensitivity of these nitrification substrates to the 


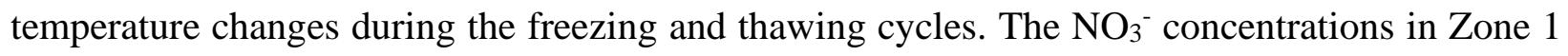
were high in the simulation because of high nitrification in this oxidized portion of the soil column. The increase and decrease of nitrification products are largely dictated by the supply of $\mathrm{NH}_{4}{ }^{+}$ entering this zone. The increasing $\mathrm{N}_{2}$ concentration in Zone 2 can be attributed to $\mathrm{N}_{2}$ serving as the denitrification end-product in this anoxic portion of the soil column.

Both measured and modeled leachate $\mathrm{NO}_{3}{ }^{-}$concentrations trend upwards following an initial delay required for the rainwater to pass through the columns. While the model does not capture the stark freeze to thaw transitions of the one-day and three-day thaws occurring around Day $\sim 30$ of the experiment, this appears to only affect the shapes of the trends. The modeled leachate $\mathrm{NO}_{3}{ }^{-}$concentration increase is more gradual than the measured leachate concentration. As Zone 2 was assumed to be entirely anoxic and dominated by denitrification, this sustained increase of leachate $\mathrm{NO}_{3}{ }^{-}$is likely bolstered by the continued contribution of recently produced $\mathrm{NO}_{3}{ }^{-}$in Zone 1. Although the measured leachate $\mathrm{NO}_{3}{ }^{-}$continued to increase until the end of the 55 days, the modeled $\mathrm{NO}_{3}{ }^{-}$concentration increase begins to level off by the end of the 60 -day fit, suggesting that measured leachate $\mathrm{NO}_{3}{ }^{-}$concentrations would have begun to decline due to denitrification if the experiment been allowed to continue.

The observed trends in measured and modeled $\mathrm{NO}_{3}^{-}$leachate concentrations have implications for future FTC nutrient leaching studies. Traditional fall NPK fertilizer applications appear susceptible to $\mathrm{NO}_{3}{ }^{-}$loss via nitrification following regular FTC and even more susceptible following intense FTC. Nitrification-inhibited or controlled-release fertilizers are commonly put forward as means of reducing overwinter $\mathrm{NO}_{3}{ }^{-}$losses from fall-applied fertilizers (Di and Cameron, 2004; Randall and Vetsch, 2005; Thapa et al., 2016), however the impacts that evolving cold climate conditions have on these commonly used preventative measures remain understudied 
(Grant et al., 2020). Nitrification inhibitor efficiency has been demonstrated to be temperature and soil type dependent (Di and Cameron, 2004; Guardia et al., 2018; McGeough et al., 2016). Thus, examining how the changes in soil temperature and structure by FTC affect the nitrification inhibitor efficacy will be important for managing agricultural pollutants in colder climates.

\subsection{Summary and Conclusions}

This study examined the effect of FTCs on nutrients leaching from unfertilized and fertilized soil columns packed with agricultural soil. There was a significant difference in $\mathrm{Cl}^{-}, \mathrm{SO}_{4}{ }^{2}$, and $\mathrm{NO}_{3}{ }^{-}$leachate concentrations between the fertilized and unfertilized soil columns. In the fertilized column leachates, the elevated $\mathrm{Cl}^{-}$and $\mathrm{SO}_{4}{ }^{2-}$ concentrations can be attributed to the initial fertilizer composition while the increase in $\mathrm{NO}_{3}{ }^{-}$concentrations are a result of the active nitrification occurring in the oxidized upper portion of the soil columns. The model simulation results from a simple plug flow reactor model were consistent with the measured $\mathrm{NO}_{3}{ }^{-}$ concentrations and indicated that intense nitrification of the urea occurred in the shallow, oxidized portion of the fertilized columns. Denitrification rates in the deeper anoxic portion of the column and immobilization mechanisms were not able to dampen leachate $\mathrm{NO}_{3}{ }^{-}$concentrations, but the end of the 60-day fit results suggested that the nitrification reactants are near exhausted by this time and leachate $\mathrm{NO}_{3}{ }^{-}$concentrations would decrease if the experiment had been allowed to continue. These findings indicate that fall-applied NPK fertilizers are prone to loss under soil FTCs during NGS and future studies should investigate the effects of winter soil processes on methods commonly used to mitigate $\mathrm{NO}_{3}{ }^{-}$losses, such as nitrification inhibitors. 


\subsection{Acknowledgements}

Funding was provided by the Canada Excellence Research Chair (CERC) program in Ecohydrology, the Global Water Futures (GWF) Winter Soil Processes in Transition project funded under the Canada First Excellence Research Fund, and Natural Sciences and Engineering Research Council (NSERC) Discovery Grant: RGPIN-2015-03801. We thank the rare Charitable Research Reserve (Cambridge, ON, Canada) for access to the field site where soil sample was collected. We also thank Marianne Vandergriendt and Shuhuan Li for assistance with laboratory experiments and analyses. We are indebted to Dr. Christina Smeaton for helpful discussions during the experimental design and data interpretations. 


\section{Investigating the Effect of Freeze-thaw Cycling on Nitrification Inhibitor Efficacy}

\subsection{Introduction}

In Chapter 2, the effects of FTCs on nutrient exports in agricultural soils were investigated by comparing nutrient leaching under fertilized and unfertilized conditions. The findings from this experiment indicated that fall-applied NPK fertilizers are prone to loss under freeze-thaw conditions during the non-growing season (NGS) and spurred the need to investigate the impacts of winter soil processes on measures commonly used to mitigate nitrate $\left(\mathrm{NO}_{3}{ }^{-}\right)$losses, such as nitrification inhibitors.

Nitrogen $(\mathrm{N})$ recovery rates for applied $\mathrm{N}$ fertilizers are soil and climate dependent but usually vary between 40-70\% (Kaleem Abbasi et al., 2003; Norton and Ouyang, 2019). N is lost via nitrification, denitrification, ammonia $\left(\mathrm{NH}_{3}\right)$ volatilization, leaching, erosion, and runoff (Chen et al., 2008; Velthof et al., 2009). This loss primarily occurs after $\mathrm{N}$ has been transformed to $\mathrm{NO}_{3}{ }^{-}$ as $\mathrm{NO}_{3}{ }^{-}$is highly mobile due its negative charge limiting adsorption to the soil matrix while denitrification products such as nitric oxide $(\mathrm{NO})$, nitrous oxide $\left(\mathrm{N}_{2} \mathrm{O}\right)$, and dinitrogen $\left(\mathrm{N}_{2}\right)$ are easily lost as gaseous emissions (Allred et al., 2007; Velthof et al., 2009). Nitrification inhibitors mitigate this loss by obstructing the conversion of $\mathrm{NH}_{4}{ }^{+}$to $\mathrm{NO}_{2}^{-}$(Zacherl and Amberger, 1990). Most inhibitors, including nitrapyrin and dicyandiamide (DCD), accomplish this via mechanismbased inhibition, serving as a substitute substrate for the ammonia monooxygenase enzyme (AMO) (McCarty, 1999; Norton and Ouyang, 2019). In this case, inhibitors inactivate AMO, preventing the turnover of $\mathrm{NH}_{3}$ to hydroxylamine (Waley, 1985).

$$
\mathrm{NH}_{3}+\mathrm{O}_{2}+2 \mathrm{H}^{+} \rightarrow \mathrm{NH}_{2} \mathrm{OH}+\mathrm{H}_{2} \mathrm{O}
$$


As $\mathrm{NH}_{4}{ }^{+}$is positively charged, it is more likely to remain bound to the soil matrix and taken up by plants. Retaining $\mathrm{N}$ in the form of $\mathrm{NH}_{4}{ }^{+}$reduces plant energy demand, as plants must reduce $\mathrm{NO}_{3}{ }^{-}$to $\mathrm{NH}_{4}{ }^{+}$prior to incorporating the $\mathrm{N}$ compound to form amino acids (Pankievicz et al., 2015). This $\mathrm{N}$ retention and decreased plant energy demand have been found to increase crop production by $7.5-13 \%$ (Abalos et al., 2014). While there are concerns that nitrification inhibitors may detrimentally impact enzyme activities unrelated to nitrification or microbial community abundance, Guo et al. (2013) found that DCD had a negligible long-term effect on non-target enzymes and microbial community abundance. The potential for nitrification inhibitors to improve $\mathrm{N}$ fertilizer efficiency and crop production makes it a promising means for both reducing $\mathrm{N}$ losses and reducing crop fertilization costs.

There are concerns of nitrification inhibitors promoting $\mathrm{NH}_{3}$ volatilization with several studies noting 10-100\% increases of $\mathrm{NH}_{3}$ emissions from soils following the application of nitrification inhibitors (Davies and Williams, 1995; Zaman et al., 2009). The proposed mechanism for this increase is the prolonged retention of $\mathrm{NH}_{4}{ }^{+}$due to nitrification inhibitor application preventing soil acidification via nitrification and maintaining an alkaline soil environment, thereby promoting conditions that are favorable for $\mathrm{NH}_{3}$ volatilization (Fox and Bandel, 1989; Recio et al., 2018). However, this increased volatilization has not been observed in all nitrification inhibitor studies measuring $\mathrm{NH}_{3}$ emission; Clay et al. (1990) and Di and Cameron (2004) observed that $\mathrm{NH}_{3}$ emissions quickly returned to background levels shortly after fertilizer and nitrification inhibitors were applied. While there are conflicting reports of the effect nitrification inhibitors have on $\mathrm{NH}_{3}$ volatilization, the possible enhancement of one $\mathrm{N}$ loss pathway may offset or negate the advantages nitrification inhibitors provide for lessening other forms of $\mathrm{N}$ loss. 
While the overall benefits of nitrification inhibitors have been demonstrated, inhibitor effectiveness is impacted by soil conditions. Temperature, soil moisture content, aeration, $\mathrm{pH}$, and microbial community composition may all impact inhibitor effectiveness. Puttanna et al. (1999) noted that DCD effectiveness decreased as soil temperatures increased from $10-30^{\circ} \mathrm{C}$ and Keeney (1980) found that nitrapyrin was more effective at lower temperatures. In a meta-analysis performed by Kelliher et al. (2008), DCD degradation was found to have a consistent temperature dependence below $10^{\circ} \mathrm{C}$. At lower temperatures, DCD degradation rates were highly sensitive to temperature changes. An increase of $1^{\circ} \mathrm{C}$ at $5^{\circ} \mathrm{C}$ resulted in a $\sim 10 \%$ decrease in DCD half-life. There is then strong evidence that nitrapyrin and DCD effectiveness generally increases with decreasing temperature. Soil moisture content also controls nitrification inhibitor efficacy. DCD has been observed to perform better at lower soil moisture conditions (Puttanna et al., 1999). At higher moisture contents, the inhibitor has been noted to be relatively mobile, dissolving into solution, leaching, and separating from the target fertilizer and nitrifying community (Marsden et al., 2016).

Aeration is closely tied to saturation and it would be expected that nitrification inhibitor studies examining soil moisture and aeration conditions would determine similar best-case scenarios. However, an experiment by Balaine et al. (2015) tested the impact of increasing aeration on DCD degradation in two agricultural soils by adjusting moisture content. They found that DCD degraded slower in soils with higher moisture contents regardless of the agricultural soil type. These contradictory results are likely the product of the dearth of studies that have examined nitrification inhibitor efficacy with respect to soil properties. Nitrification inhibitor effectiveness has been demonstrated to be affected by $\mathrm{pH}$, but the sparse amount of studies focusing on this 
matter and the wide range of inhibitors used limits any generalizations that can be made between nitrification inhibitor effectiveness and pH (Keeney, 1980; R. Liu et al., 2015).

This variability in nitrification inhibitor efficacy and the differing responses of nitrification inhibitors to similar soil conditions necessitates that inhibitors be examined under future anticipated climate conditions. There are few studies investigating the interaction between freezethaw events and $\mathrm{N}$ losses from nitrification inhibited and fertilized soil. To address this knowledge gap, a sacrificial soil jar batch experiment was conducted with the intent to elucidate the interaction between this winter soil process and popular nitrification inhibitors.

\subsection{Materials and Methods}

\subsubsection{Soil Collection and Properties}

Soil for this sacrificial batch experiment was collected from an agricultural field at the rare Charitable Research Reserve in Cambridge, Ontario (latitude $43^{\circ} 22^{\prime} 39.80^{\prime \prime N}$; longitude $80^{\circ} 22^{\prime} 07.28^{\prime \prime} \mathrm{W}$ ) (the same location as described in Chapter 2; see 2.2.1 for more details about the field site and soil characteristics) in October 2019. At the time, the field was planted in corn and in previous years it was rotated in soy, corn and wheat and red clover. Collected soil was sieved to $2 \mathrm{~mm}$, homogenized, air dried for 1 week and then stored at $4^{\circ} \mathrm{C}$ until the experiment commenced.

\subsubsection{Sacrificial Soil Jar Batch Experiment}

Allocations of $200 \mathrm{~g}$ of the homogenized soils were weighed into $500 \mathrm{~mL}$ glass jars (soil surface area: approximately $35 \mathrm{~cm}^{2}$ ). The soil samples were prepared in three treatments (unfertilized, fertilized, and inhibited) and under thawed $\left(4^{\circ} \mathrm{C}\right)$, frozen $\left(-10^{\circ} \mathrm{C}\right)$, and freeze-thaw cycle (FTC) (between $-10^{\circ} \mathrm{C}$ and $4^{\circ} \mathrm{C}$ ) conditions for a total of 108 samples. Jars selected for the 
unfertilized condition were saturated to $60 \%$ gravimetric soil water content with artificial pore water with a chemical composition containing $\mathrm{Cl}^{-}\left(195.0 \mathrm{mg} \mathrm{L}^{-1}\right), \mathrm{SO}_{4}{ }^{2-}\left(19.2 \mathrm{mg} \mathrm{L}^{-1}\right), \mathrm{NO}_{3}{ }^{-}(18.6$ $\left.\mathrm{mg} \mathrm{L}^{-1}\right), \mathrm{Na}^{+}\left(8.0 \mathrm{mg} \mathrm{L}^{-1}\right), \mathrm{Ca}^{2+}\left(78.0 \mathrm{mg} \mathrm{L}^{-1}\right), \mathrm{Mg}^{2+}\left(28.0 \mathrm{mg} \mathrm{L}^{-1}\right)$, and $\mathrm{K}^{+}\left(0.8 \mathrm{mg} \mathrm{L}^{-1}\right)$. Jars selected for the fertilized condition were saturated with a similar solution incorporating $0.2 \mathrm{~g}$ of 15-30-15 NPK Miracle-Gro while jars selected for the inhibited condition were saturated with the fertilized solution containing $40 \mathrm{mg} \mathrm{L}^{-1}$ of nitrapyrin and $50 \mathrm{mg} \mathrm{L}^{-1}$ of DCD. These nitrification inhibitor concentration values were selected from a literature review and were exaggerated compared to common inhibitor use concentrations to ensure a strong inhibition effect would be observed (Magalhães et al., 1984; McTaggart et al., 1997; Parkin, 1987). Thaw jars were placed in a fridge and were kept at $4^{\circ} \mathrm{C}$, frozen jars were placed in an environmental chamber incubator (Percival I-41NL XC9) and were kept at $-10^{\circ} \mathrm{C}$, and thaw jars were placed in another environmental chamber incubator with the temperature set to oscillate between $-10^{\circ} \mathrm{C}$ and $4^{\circ} \mathrm{C}$ (Figure 3-1). The experiment was run for a total of 37 days due to extraordinary circumstances related to the COVID-19 pandemic. 


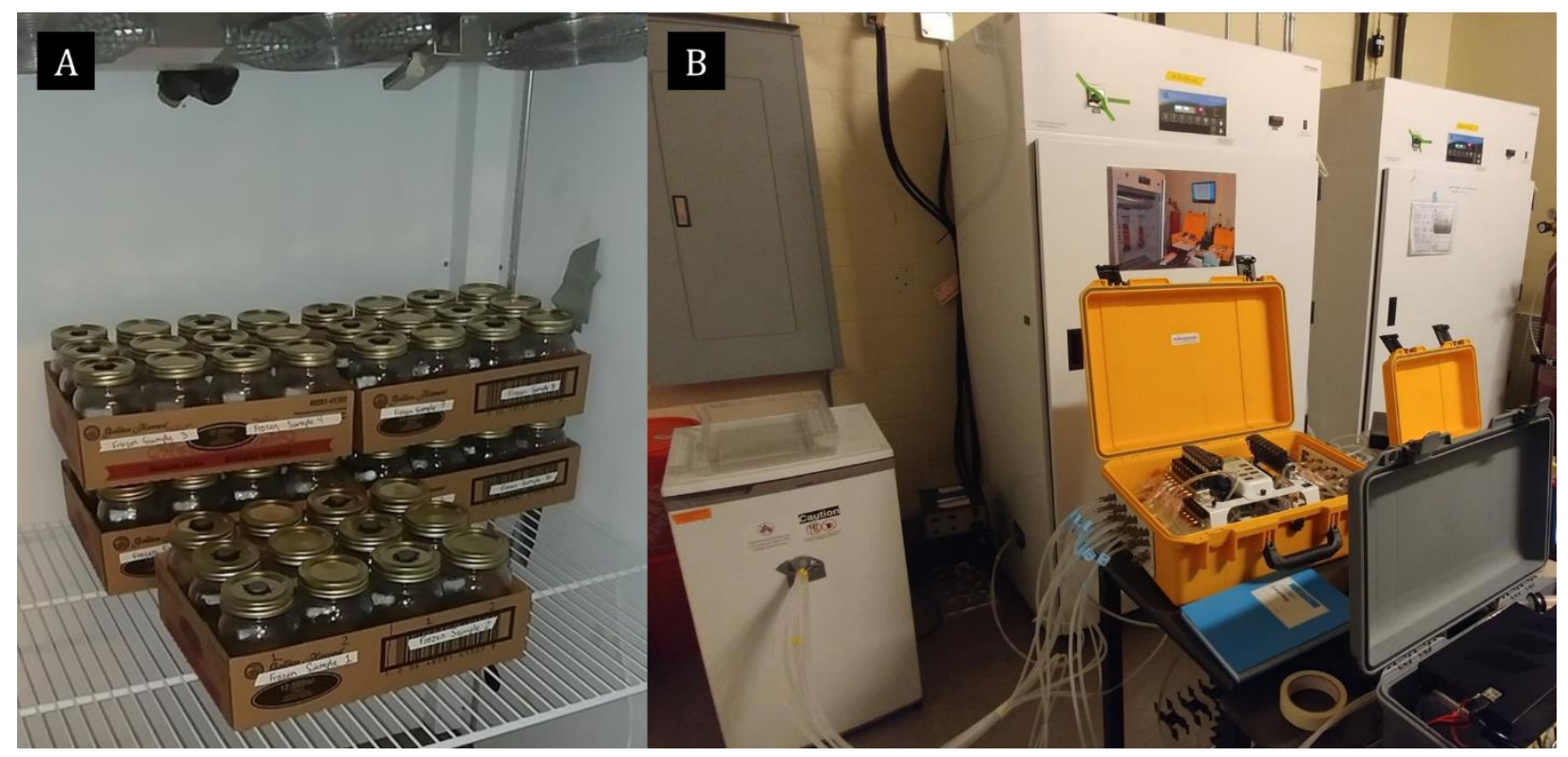

Figure 3-1. Photos of freeze-thaw cycle soil jars in Percival environmental chamber following saturation and addition of fertilizer and inhibitors to appropriate jars (A) and fridge used for storing samples at the thaw condition and environmental chambers used for storing samples at frozen and freeze-thaw cycle condition (B).

\subsubsection{Pore water Sampling and Analytical Methods}

Duplicate soil jars were extracted once a week with duplicate freeze jars extracted one day prior to thaw to allow for pore water extraction. Soil samples were centrifuged in $50 \mathrm{~mL}$ Falcon centrifuge tubes at 10,000 RPM for 4 minutes. Sampled pore water was then filtered through a 0.2 $\mu \mathrm{m}$ membrane filter (Thermo Scientific Polysulfone filter). Filtered pore water was analyzed for $\mathrm{pH}$ and EC using handheld meters (LAQUA Twin meters, model Horiba B-213). DOC and TN concentrations of filtered pore water (acidified to $\mathrm{pH}<3$ using $1 \mathrm{M} \mathrm{HCl}$ ) were measured using a total organic carbon analyzer (Shimadzu TOC-LCPH/CPN). DIC concentrations were measured using the same instrument and non-acidified filtered pore water. Approximately $1 \mathrm{~mL}$ of filtered pore water was frozen for later analysis of major anions including chloride $\left(\mathrm{Cl}^{-}\right)$, nitrate $\left(\mathrm{NO}_{3}^{-}\right)$, and sulfate $\left(\mathrm{SO}_{4}{ }^{2-}\right)$ using ion chromatography (IC, Dionex ICS-5000 with a capillary IonPac® AS18 column; $\pm 3.0 \%$ error and $\pm 1.6 \%$ precision; see Figures A-4, A-5, and A-6). 


\subsection{Results and Discussion}

The $\mathrm{NO}_{3}{ }^{-}$concentrations in frozen samples remained relatively stable across all fertilizer conditions over the course of the experiment, with fertilized and inhibited jar $\mathrm{NO}_{3}{ }^{-}$concentrations fluctuating between 225 and $350 \mathrm{mg} \mathrm{L}^{-1}$ during the whole experiment (Figure 3-2). Unfertilized samples $\mathrm{NO}_{3}{ }^{-}$concentrations were noticeably lower than the fertilized and inhibited samples. This difference can be attributed to the lack of additional $\mathrm{N}$ input into the soil samples from the fertilizer. As the nitrification and denitrification are not likely to transpire at subzero temperatures (Cookson et al., 2002; Taylor et al., 2017), the relatively stable $\mathrm{NO}_{3}{ }^{-}$concentrations are then expected given little to no nitrification or denitrification is likely to occur at $-10^{\circ} \mathrm{C}$. However, as the pore water of frozen samples had to be allowed to thaw prior to sampling, this effective single freeze-thaw condition did not appear to stimulate significant nitrification or denitrification using $\mathrm{NO}_{3}{ }^{-}$ concentration changes as a proxy for observing either of these processes.

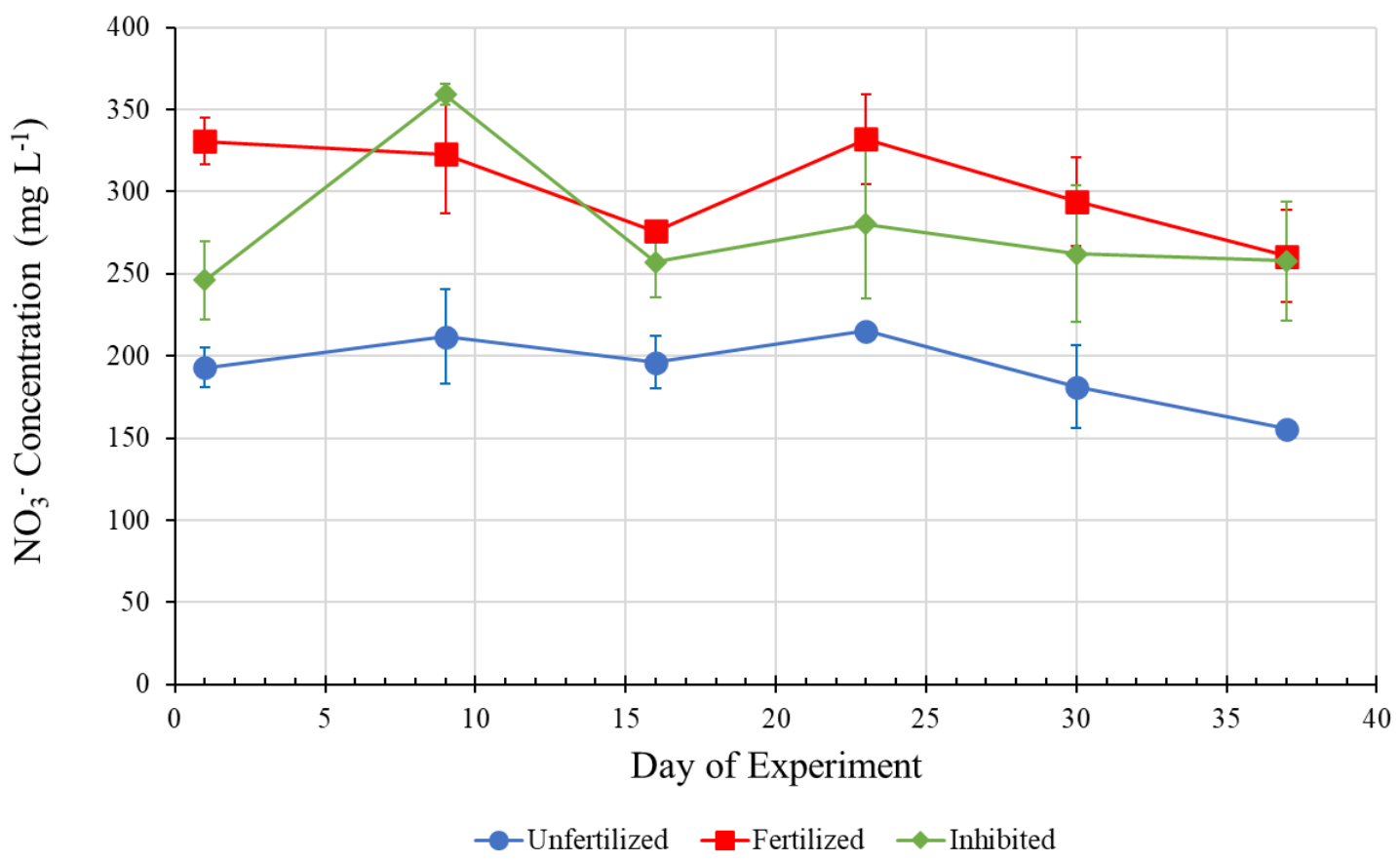

Figure 3-2. $\mathrm{NO}_{3}{ }^{-}$concentrations versus time for unfertilized, fertilized, and inhibited samples in the freeze condition. 
Unlike the slight decrease of $\mathrm{NO}_{3}{ }^{-}$concentrations in unfertilized soils in the frozen condition, $\mathrm{NO}_{3}{ }^{-}$concentrations in the unfertilized samples in the thaw condition increased slightly over the duration of the experiment, suggesting moderate nitrification occurred in these duplicate samples (Figure 3-3). $\mathrm{NO}_{3}{ }^{-}$concentrations dramatically increased in the thaw condition for both fertilized and inhibited samples, similar to the $\mathrm{NO}_{3}{ }^{-}$leaching results from the fertilized soil columns presented in Chapter 2. The $\mathrm{NO}_{3}{ }^{-}$concentrations in thawed fertilized and inhibited samples increased to $\sim 1,000 \mathrm{mg} \mathrm{L}^{-1}$ and $\sim 650 \mathrm{mg} \mathrm{L}^{-1}$, respectively, by the end of the experiment. Comparing the $\mathrm{NO}_{3}{ }^{-}$concentrations in fertilized and inhibited samples, the nitrapyrin and DCD reduced the $\mathrm{NO}_{3}^{-}$production by about $51 \%$. This reduction in $\mathrm{NO}_{3}^{-}$production was likely accomplished by inhibiting $\mathrm{NH}_{4}{ }^{+}$oxidation and is comparable to nitrification inhibitor reductions to $\mathrm{NO}_{3}{ }^{-}$production reported in previous studies (Cui et al., 2011; Di and Cameron, 2005; Di and Cameron, 2007). Considering the fertilized and inhibited samples had similar $\mathrm{NO}_{3}{ }^{-}$concentrations at the onset of the experiment, this demonstrates that nitrapyrin and DCD effectively mitigated the $\mathrm{NO}_{3}$ production in the fertilized agricultural soil. 


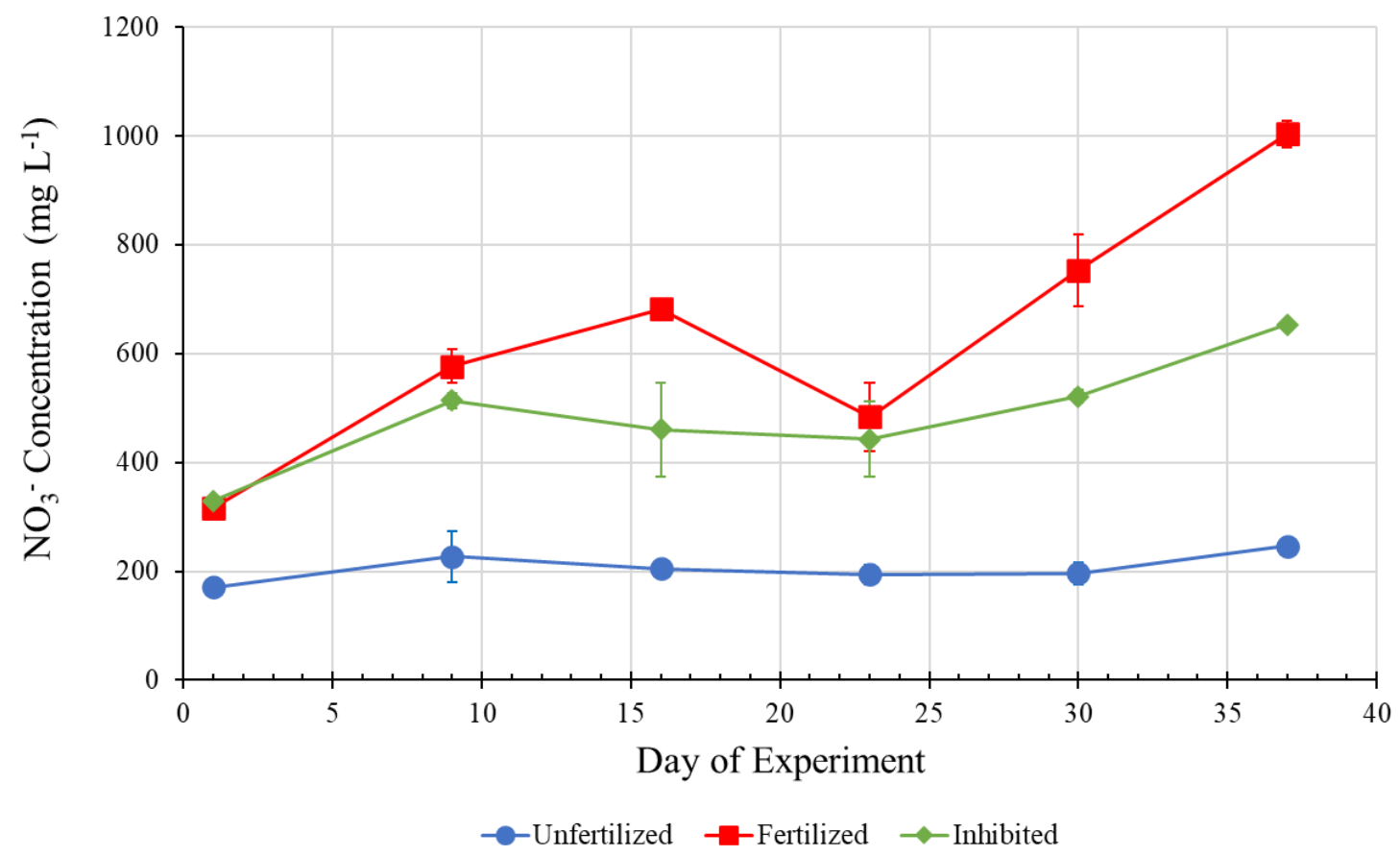

Figure 3-3. $\mathrm{NO}_{3}{ }^{-}$concentrations versus time for unfertilized, fertilized, and inhibited samples in the thaw condition.

For the FTC condition, fertilizer $\mathrm{NO}_{3}{ }^{-}$concentrations increased by $50 \%$ while inhibited $\mathrm{NO}_{3}{ }^{-}$concentrations increased by $43 \%$ under FTC conditions (Figure 3-4). This slight reduction in $\mathrm{NO}_{3}{ }^{-}$production by DCD was also observed in a freeze-thaw laboratory experiment conducted by Hamamoto et al. (2020) who found DCD to reduce $\mathrm{NO}_{3}{ }^{-}$concentrations significantly. Nitrification rates were significantly lower under the FTC condition compared to the thaw condition, where the fertilizer sample $\mathrm{NO}_{3}{ }^{-}$concentrations increased by $223 \%$ while inhibited sample $\mathrm{NO}_{3}{ }^{-}$ concentrations increased only by $99 \%$. While the nitrification inhibitors clearly stymied $\mathrm{NO}_{3}{ }^{-}$ production in the FTC condition, the nitrification inhibitors had a much lower effect than under the thaw condition. 


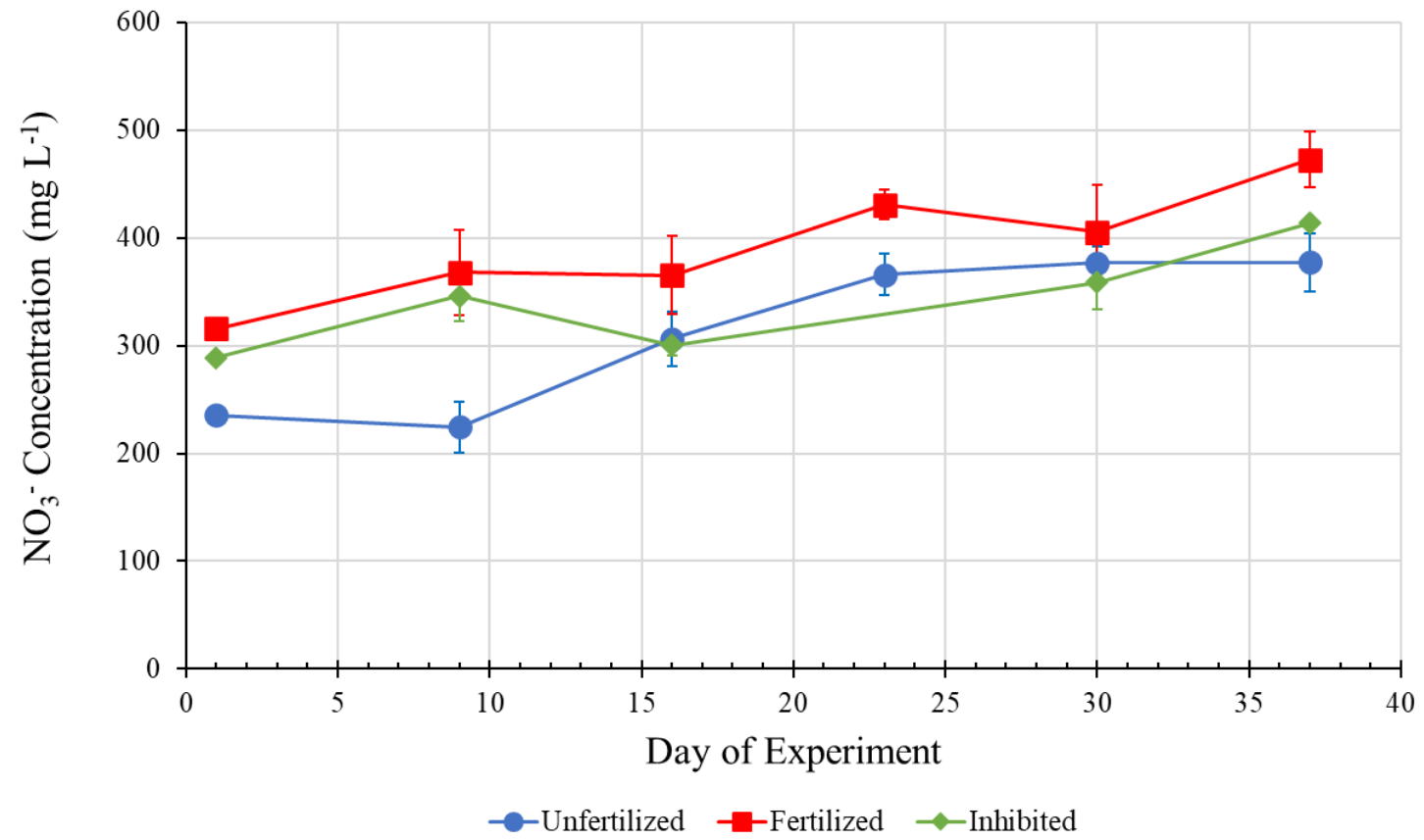

Figure 3-4. $\mathrm{NO}_{3}{ }^{-}$concentrations versus time for unfertilized, fertilized, and inhibited samples in the FTC condition.

Unlike in the freeze and thaw conditions, concentration of $\mathrm{NO}_{3}{ }^{-}$in unfertilized samples increased for the entirety of the experiment, with $\mathrm{NO}_{3}{ }^{-}$production comparable to the fertilized samples. This suggests that $\mathrm{NO}_{3}{ }^{-}$mineralization was enhanced by freezing and thawing cycles assuming all released inorganic $\mathrm{N}$ would be converted to $\mathrm{NO}_{3}{ }^{-}$under nitrifying conditions. This is in line with the results of other previous studies that have reported $\mathrm{N}$ mineralization increases following freeze-thaw events (DeLuca et al., 1992; Herrmann and Witter, 2002; Van Bochove et al., 2001). This differs from the results presented in Chapter 2 that suggested FTCs had little to no impact on $\mathrm{N}$ mineralization. This difference in mineralization could be the result of differences in $\mathrm{N}$ turnover rates between the first soil column experiment (Chapter 2) and the FTC condition of the batch experiment (Chapter 3). If the rates of microbial immobilization of inorganic $\mathrm{N}$ were high enough in the first column experiment, the apparent effect of FTCs on $\mathrm{N}$ mineralization could be masked by high immobilization rates. Inorganic $\mathrm{N}$ released from the soil would then be quickly assimilated prior to be nitrified to $\mathrm{NO}_{3}{ }^{-}$under this circumstance. 
The difference in nitrification inhibitor efficacy between the thaw and FTC conditions could be attributed to the duration of the soil jar batch experiment. The consistent moisture content, aeration, and substrate supply conditions of the thawed samples could have engendered conditions more favorable for $\mathrm{NO}_{3}{ }^{-}$production via nitrification than the periodic thawed conditions of the FTC samples. The expected higher half-life of nitrification inhibitors at lower temperatures may not have impacted FTC nitrification inhibitor efficacy given the timeline of the experiment. Colder soil temperatures have been noted to extend the lifetime of DCD in a long term pasture study (de Klein et al., 2014). If the experiment continued for longer it is possible that degradation of the nitrification inhibitors may have occurred for the thaw inhibited condition. This would then lead to comparable rates of $\mathrm{NO}_{3}{ }^{-}$production between the thaw inhibited and thaw fertilized conditions. Overall nitrification inhibitor efficacy under FTC condition might be greater than inhibitor efficacy at low temperatures considering real world nitrification inhibitor use timelines.

The reduced inhibition of $\mathrm{NO}_{3}{ }^{-}$production in the FTC samples may also be due to the priming effect nitrification inhibitors have on fertilized soils, enhancing $\mathrm{N}$ mineralization relative to soils that are fertilized without inhibitors (Gioacchini et al., 2002). The priming effect is attributed to the stimulation of microbial activity that occurs following $\mathrm{N}$ input into the system that results in increased SOM mineralization (Kuzyakov et al., 2000). Although both the thawed and FTC inhibited condition received the same $\mathrm{N}$ and inhibitor input, the priming effect may have been more pronounced in the FTC inhibited condition with mineralized inorganic $\mathrm{N}$ in the thaw inhibited samples being mostly assimilated. Increased $\mathrm{N}$ mineralization could then explain the elevated $\mathrm{NO}_{3}{ }^{-}$production observed in this condition.

There was a clear difference in $\mathrm{Cl}^{-}$and $\mathrm{SO}_{4}{ }^{2-}$ concentration trends between the sacrificial soil batch experiment and the soil column experiment. $\mathrm{Cl}^{-}$and $\mathrm{SO}_{4}{ }^{2-}$ concentrations for the soil 
samples in the sacrificial batch experiment were stable throughout the duration of the experiment for all fertilizer treatment and temperature conditions while $\mathrm{Cl}^{-}$and $\mathrm{SO}_{4}{ }^{2-}$ concentrations in the fertilized soil column leachates fluctuated (see Figures A-3 and A-4). This difference can be attributed to a lack of flow in the soil batch samples and corroborates the assumption that the observed increase and decrease of $\mathrm{Cl}^{-}$and $\mathrm{SO}_{4}{ }^{2-}$ concentrations noted in the fertilized soil column leachates was a product of transport dynamics (see 2.4.1).

\subsection{Conclusions}

This chapter provided a brief examination into how FTC affects nitrification inhibitor efficacy. A brief review of the literature examining how various environmental factors interact with nitrification inhibitor efficacy revealed a dearth of studies evaluating the impact of FTCs on nitrification inhibitor efficacy. Although the COVID-19 pandemic limited the duration of the experiment, the results of the sacrificial soil batch experiment demonstrate that nitrification inhibitor efficacy is impacted by FTCs. Additionally, the differing $\mathrm{N}$ mineralization results between sacrificial batch experiment and the soil column experiment (Chapter 2) resemble the contrasting findings reported in the literature as several studies have reported either an increase or decrease in net $\mathrm{N}$ mineralization after freezing and thawing. This uncertain relationship requires further investigation to develop a mechanistic-based understanding of what freeze-thaw study parameter variables and thresholds lead to enhanced or reduced $\mathrm{N}$ mineralization following FTCs. 


\section{Conclusions and Future Research}

\subsection{Summary of Key Findings}

In this thesis, I sought to improve understanding of how winter soil processes impact nutrient leaching and fertilizer efficacy in cold region agroecosystem. In Chapter 2, I examined the potential impact of freeze-thaw cycles (FTCs) on nitrogen (N) losses from fertilized agricultural soils. To accomplish this, I conducted a non-growing season (NGS) soil column experiment using duplicate fertilized and unfertilized soil columns. $\mathrm{N}$ species concentrations in column leachates were measured to determine net $\mathrm{N}$ transformation and the results demonstrated that freeze-thaw cycling can stimulate significant loss of nitrate $\left(\mathrm{NO}_{3}^{-}\right)$in soils fertilized with urea. $\mathrm{NO}_{3}{ }^{-}$concentrations in the fertilized column leachates increased for the duration of the latter half of the experiment while unfertilized column leachate $\mathrm{NO}_{3}{ }^{-}$concentrations were consistently low throughout the experiment.

While the measured input and output $\mathrm{N}$ species would indicate that nitrification was responsible for the increasing fertilized column leachate concentrations, denitrification is the commonly observed FTC response in the literature. To verify experimental results, an associated simple plug flow reactor model was developed accounting for the various nitrification reactions and a net denitrification reaction. Model results indicate that urea hydrolyzes within the first 20 days of the experiment and the ensuing products are nitrified in the shallow, aerated portion of the soil column. A portion of this created $\mathrm{NO}_{3}{ }^{-}$pool is then denitrified to dinitrogen $\left(\mathrm{N}_{2}\right)$ but a larger fraction leaches from the bottom of the soil columns. Both the experimental and model results indicate that freeze-thaw processes may induce nitrification and stressed the need to examine how the temperature and soil structure changes inherent to FTC affect recommended methods of reducing $\mathrm{NO}_{3}^{-}$losses. 
In Chapter 3, the sacrificial batch experiment demonstrated that nitrification inhibitor efficacy is affected by FTC. This result requires further investigation but may indicate nutrient management strategies that put forward nitrification inhibitors as a means of reducing $\mathrm{NO}_{3}{ }^{-}$loss from fall-applied fertilizers need to be revisited and possibly reworked, especially for agricultural regions that are expected to be exposed to more NGS FTC in the near future. Additionally, this sacrificial batch experiment indicated that FTCs are likely to increase $\mathrm{N}$ mineralization while the first experiment results suggested FTCs had little to no effect on N mineralization. Some studies suggest that freeze intensity is the most important factor as to whether FTC enhances $\mathrm{N}$ mineralization. As the FTC temperature changes utilized in this sacrificial batch experiment were greater than the temperature changes utilized in the soil column experiment, perhaps the determining factor for whether FTC will affect $\mathrm{N}$ mineralization is the amplitude of freezing and thawing.

\subsection{Recommendations for Future Research}

The experiment described in Chapter 2 provided an interesting characterization of fertilizer-rich infiltration front passing through a soil profile exposed to freeze-thaw conditions, but several adjustments could be made to this study design that would make for another experiment worth conducting. The leachate collection method utilized in the first experiment only allowed for net pore water concentration changes to be observed. Matzner and Borken (2008) note that in situ soil $\mathrm{N}$ concentration measurements provide a clear link between FTCs and their effect on $\mathrm{N}$ leaching. An in-situ Ion Chromatograph integrated into a soil column experiment would allow for higher resolution, more frequent analysis of $\mathrm{N}$ speciation changes over the soil column depth profile (Murray et al., 2020). Leachate and simple plug flow reactor results suggest the applied fertilizer migrated through the column as a front, but the concentration distribution of $\mathrm{N}$ species 
was not well captured. In-situ analysis across depth would provide a more accurate picture of this fertilizer front progressing through the soil column. Additionally, including a non-FTC control column and recording output leachate volumes in this proposed in-situ experiment would reduce uncertainty regarding nutrient transformations that can be attributed to FTC and allow for accurate mass balancing.

The differing results of the experiments performed in Chapters 2 and 3 suggest that a study examining $\mathrm{N}$ mineralization under varying FTC conditions would be useful to conduct. The literature survey conducted in Chapter 2 indicate that this difference exists in the literature as well. Performing a series of sacrificial soil batch experiments accounting for numerous FTC temperature change and duration conditions imposed on different agricultural soil types could elucidate the experiment methodological differences in FTC studies that lead to both reports of FTCs reducing, increasing, or not affecting $\mathrm{N}$ mineralization. Isolating the natural background contribution of organic $\mathrm{N}$ to inorganic $\mathrm{N}$ losses would inform NGS $\mathrm{N}$ mineralization models and allow for the construction of more accurate annual $\mathrm{N}$ budgets.

For both the soil column and the sacrificial batch experiments, the duration of the experiments may not have allowed for the observance of the long-term effects a series of FTCs can have on fertilized or inhibited agricultural soils. In the case of the soil column experiment, $\mathrm{NO}_{3}{ }^{-}$losses continued to increase until the end of the experiment but modeling results suggest $\mathrm{NO}_{3}{ }^{-}$ leachate concentrations would have begun to decline had the experiment been allowed to run longer. For the shorter soil batch experiment, the importance of inhibitor half-life was underplayed by the 37 duration of the experiment, especially in the warmer thaw condition. To better understand the long-term effects of freeze-thaw cycling on agroecosystems, conducting an extended soil batch experiment examining the effect of FTCs on unfertilized, fertilized, and inhibited agricultural soil 
pore water composition and gaseous emissions would allow for a more complete understanding of soil $\mathrm{N}$ transformations and fluxes to be developed. While soil batch experiments do not serve as perfect analogue for field conditions and may fail to capture the variability inherent to open systems, they can help pinpoint NGS N fluxes of concern in climate altered agricultural soils. 


\section{References}

Abalos, D., Jeffery, S., Sanz-Cobena, A., Guardia, G., \& Vallejo, A. (2014). Meta-analysis of the effect of urease and nitrification inhibitors on crop productivity and nitrogen use efficiency. $\begin{array}{lllll}\text { Agriculture, } \quad \text { Ecosystems } \quad \& \quad \text { Environment, } & 189,\end{array}$ https://doi.org/10.1016/j.agee.2014.03.036

Ågren, G. I., Wetterstedt, J. Å. M., \& Billberger, M. F. K. (2012). Nutrient limitation on terrestrial plant growth - modeling the interaction between nitrogen and phosphorus. New Phytologist, 194(4), 953-960. https://doi.org/https://doi.org/10.1111/j.1469-8137.2012.04116.x

Allred, B. J., Brown, G. O., \& Bigham, J. M. (2007). NITRATE MOBILITY UNDER UNSATURATED FLOW CONDITIONS IN FOUR INITIALLY DRY SOILS. Soil Science, 172(1). https://journals.lww.com/soilsci/Fulltext/2007/01000/NITRATE_MOBILITY_UNDER_U NSATURATED_FLOW_CONDITIONS.4.aspx

Almasri, M. N., \& Kaluarachchi, J. J. (2004). Assessment and management of long-term nitrate pollution of ground water in agriculture-dominated watersheds. Journal of Hydrology, 295(1), 225-245. https://doi.org/https://doi.org/10.1016/j.jhydrol.2004.03.013

AMAP. (2012). Arctic Climate Issues 2011: Changes in Arctic Snow, Water, Ice and Permafrost.

Ambus, P. (1993). Control of denitrification enzyme activity in a streamside soil. FEMS Microbiology Ecology, 11(3-4), 225-234. https://doi.org/10.1111/j.15746968.1993.tb05814.x

Balaine, N., Clough, T. J., Kelliher, F. M., \& van Koten, C. (2015). Soil aeration affects the degradation rate of the nitrification inhibitor dicyandiamide. Soil Research, 53, 137+. https://link.gale.com/apps/doc/A410387649/AONE?u=uniwater\&sid=AONE\&xid=8de8beb 0

Bateman, E. J., \& Baggs, E. M. (2005). Contributions of nitrification and denitrification to N2O emissions from soils at different water-filled pore space. Biology and Fertility of Soils, 41(6), 379-388. https://doi.org/10.1007/s00374-005-0858-3

Beach, H. M., Laing, K. W., van de Walle, M., \& Martin, R. C. (2018). The current state and future directions of organic no-till farming with cover crops in Canada, with case study support. Sustainability (Switzerland), 10(2), 1-15. https://doi.org/10.3390/su10020373

Benbi, D. K., \& Richter, J. (2002). A critical review of some approaches to modelling nitrogen mineralization. Biology and Fertility of Soils, 35(3), 168-183. 
https://doi.org/10.1007/s00374-002-0456-6

Blum, W. (2005). Soils and climate change. Journal of Soils and Sediments, 5(2), 67.

Bollmann, A., \& Conrad, R. (1998). Influence of O2 availability on NO and N2O release by nitrification and denitrification in soils. Global Change Biology, 4(4), 387-396. https://doi.org/https://doi.org/10.1046/j.1365-2486.1998.00161.x

Boyer, E. W., Goodale, C. L., Jaworski, N. A., \& Howarth, R. W. (2002). Anthropogenic Nitrogen Sources and Relationships to Riverine Nitrogen Export in the Northeastern U.S.A. Biogeochemistry, $\quad$ 57/58, $137-169$. http://www.jstor.org.proxy.lib.uwaterloo.ca/stable/1469687

Braker, G., Schwarz, J., \& Conrad, R. (2010). Influence of temperature on the composition and activity of denitrifying soil communities. FEMS Microbiology Ecology, 73(1), 134-148. https://doi.org/10.1111/j.1574-6941.2010.00884.x

Bremer, C., Braker, G., Matthies, D., Beierkuhnlein, C., \& Conrad, R. (2009). Plant presence and species combination, but not diversity, influence denitrifier activity and the composition of nirK-type denitrifier communities in grassland soil. FEMS Microbiology Ecology, 70(3), 377-387. https://doi.org/10.1111/j.1574-6941.2009.00732.x

Brown, R. D. (2000). Northern Hemisphere Snow Cover Variability and Change, 1915-97. Journal of Climate, 13(13), 2339-2355. https://doi.org/10.1175/15200442(2000)013<2339:NHSCVA>2.0.CO;2

Burney, J. A., Davis, S. J., \& Lobell, D. B. (2010). Greenhouse gas mitigation by agricultural intensification. Proceedings of the National Academy of Sciences, 107(26), 12052 LP 12057. https://doi.org/10.1073/pnas.0914216107

Butterbach-Bahl, K., Baggs, E. M., Dannenmann, M., Kiese, R., \& Zechmeister-Boltenstern, S. (2013). Nitrous oxide emissions from soils: how well do we understand the processes and their controls? Philosophical Transactions of the Royal Society of London. Series B, Biological Sciences, 368(1621), 20130122. https://doi.org/10.1098/rstb.2013.0122

Buyer, J. S., Teasdale, J. R., Roberts, D. P., Zasada, I. A., \& Maul, J. E. (2010). Factors affecting soil microbial community structure in tomato cropping systems. Soil Biology and Biochemistry, 42(5), 831-841. https://doi.org/https://doi.org/10.1016/j.soilbio.2010.01.020

Campbell, J. L., Ollinger, S. V, Flerchinger, G. N., Wicklein, H., Hayhoe, K., \& Bailey, A. S. (2010). Past and projected future changes in snowpack and soil frost at the Hubbard Brook Experimental Forest, New Hampshire, USA. Hydrological Processes, 24(17), 2465-2480. https://doi.org/10.1002/hyp.7666 
Campbell, J. L., Socci, A. M., \& Templer, P. H. (2014). Increased nitrogen leaching following soil freezing is due to decreased root uptake in a northern hardwood forest. Global Change Biology, 20(8), 2663-2673. https://doi.org/10.1111/gcb.12532

Chantigny, M. H., Bittman, S., Larney, F. J., Lapen, D., Hunt, D. E., Goyer, C., \& Angers, D. A. (2019). A multi-region study reveals high overwinter loss of fall-applied reactive nitrogen in cold and frozen soils. Canadian Journal of Soil Science, 99(2), 126-135. https://doi.org/10.1139/cjss-2018-0151

Chen, D., Suter, H., Islam, A., Edis, R., Freney, J. R., \& Walker, C. N. (2008). Prospects of improving efficiency of fertiliser nitrogen in Australian agriculture: a review of enhanced efficiency fertilisers. Soil Research, 46(4), 289-301. https://doi.org/10.1071/SR07197

Clark, K., Chantigny, M. H., Angers, D. A., Rochette, P., \& Parent, L.-É. (2009). Nitrogen transformations in cold and frozen agricultural soils following organic amendments. Soil Biology and Biochemistry, 41(2), 348-356. https://doi.org/https://doi.org/10.1016/j.soilbio.2008.11.009

Clay, D. E., Malzer, G. L., \& Anderson, J. L. (1990). Ammonia Volatilization from Urea as Influenced by Soil Temperature, Soil Water Content, and Nitrification and Hydrolysis Inhibitors. Soil Science Society of America Journal, 54(1), 263-266. https://doi.org/https://doi.org/10.2136/sssaj1990.03615995005400010042x

Conant, B. (2004). Delineating and Quantifying Ground Water Discharge Zones Using Streambed Temperatures. Ground Water, 42(2), 243-257.

Cookson, W. R., Cornforth, I. S., \& Rowarth, J. S. (2002). Winter soil temperature $\left(2-15^{\circ} \mathrm{C}\right)$ effects on nitrogen transformations in clover green manure amended or unamended soils; a laboratory and field study. Soil Biology and Biochemistry, 34(10), 1401-1415. https://doi.org/https://doi.org/10.1016/S0038-0717(02)00083-4

Čuhel, J., \& Šimek, M. (2011). Effect of pH on the denitrifying enzyme activity in pasture soils in relation to the intrinsic differences in denitrifier communities. Folia Microbiologica, 56(3), 230-235. https://doi.org/10.1007/s12223-011-0045-x

Cui, M., Sun, X., Hu, C., Di, H. J., Tan, Q., \& Zhao, C. (2011). Effective mitigation of nitrate leaching and nitrous oxide emissions in intensive vegetable production systems using a nitrification inhibitor, dicyandiamide. Journal of Soils and Sediments, 11(5), 722-730. https://doi.org/10.1007/s11368-011-0357-0

Daims, H., Lebedeva, E. V, Pjevac, P., Han, P., Herbold, C., Albertsen, M., Jehmlich, N., Palatinszky, M., Vierheilig, J., Bulaev, A., Kirkegaard, R. H., von Bergen, M., Rattei, T., Bendinger, B., Nielsen, P. H., \& Wagner, M. (2015). Complete nitrification by Nitrospira 
bacteria. Nature, 528(7583), 504-509. https://doi.org/10.1038/nature16461

Davidson, E. A. (1992). Sources of Nitric Oxide and Nitrous Oxide following Wetting of Dry Soil. Soil Science Society of America Journal, 56(1), 95-102. https://doi.org/https://doi.org/10.2136/sssaj1992.03615995005600010015x

Davies, D. M., \& Williams, P. J. (1995). The Effect of the Nitrification Inhibitor Dicyandiamide on Nitrate Leaching and Ammonia Volatilization: A U.K. Nitrate Sensitive Areas Perspective. Journal of Environmental Management, 45(3), 263-272. https://doi.org/https://doi.org/10.1006/jema.1995.0074

de Klein, C. A. M., Letica, S. A., \& Macfie, P. I. (2014). Evaluating the effects of dicyandiamide (DCD) on nitrogen cycling and dry matter production in a 3-year trial on a dairy pasture in South Otago, New Zealand. New Zealand Journal of Agricultural Research, 57(4), 316-331. https://doi.org/10.1080/00288233.2014.941508

Del Grosso, S. J., Parton, W. J., Mosier, A. R., Ojima, D. S., Kulmala, A. E., \& Phongpan, S. (2000). General model for $\mathrm{N} 2 \mathrm{O}$ and $\mathrm{N} 2$ gas emissions from soils due to dentrification. Global Biogeochemical Cycles, 14(4), 1045-1060. https://doi.org/https://doi.org/10.1029/1999GB001225

DeLuca, T. H., Keeney, D. R., \& McCarty, G. W. (1992). Effect of freeze-thaw events on mineralization of soil nitrogen. Biology and Fertility of Soils, 14(2), 116-120. https://doi.org/10.1007/BF00336260

Dessureault-Rompré, J., Zebarth, B., Georgallas, A., Burton, D., Grant, C., \& Drury, C. (2010). Temperature dependence of soil nitrogen mineralization rate: Comparison of mathematical models, reference temperatures and origin of the soils. Geoderma, 157, 97-108. https://doi.org/10.1016/j.geoderma.2010.04.001

Dessureault-Rompré, J., Zebarth, B. J., Burton, D. L., \& Georgallas, A. (2014). Predicting soil nitrogen supply from soil properties. Canadian Journal of Soil Science, 95(1), 63-75. https://doi.org/10.4141/cjss-2014-057

Di, H. J., \& Cameron, K. C. (2004). Effects of temperature and application rate of a nitrification inhibitor, dicyandiamide (DCD), on nitrification rate and microbial biomass in a grazed pasture soil. Australian Journal of Soil Research, 42(8), 927-932. https://doi.org/10.1071/SR04050

Di, H J, \& Cameron, K. C. (2005). Effects of temperature and application rate of a nitrification inhibitor, dicyandiamide (DCD), on nitrification rate and microbial biomass in a grazed pasture soil. Soil Research, 42(8), 927-932. 
Di, Hong J, \& Cameron, K. C. (2007). Nitrate leaching losses and pasture yields as affected by different rates of animal urine nitrogen returns and application of a nitrification inhibitor-a lysimeter study. Nutrient Cycling in Agroecosystems, 79(3), 281-290. https://doi.org/10.1007/s10705-007-9115-5

Ehrl, B. N., Gharasoo, M., \& Elsner, M. (2018). Isotope Fractionation Pinpoints Membrane Permeability as a Barrier to Atrazine Biodegradation in Gram-negative Polaromonas sp. Nea-C. Environmental Science \& Technology, 52(7), 4137-4144. https://doi.org/10.1021/acs.est.7b06599

Elberling, B., \& Brandt, K. K. (2003). Uncoupling of microbial CO2 production and release in frozen soil and its implications for field studies of arctic C cycling. Soil Biology and Biochemistry, 35(2), 263-272. https://doi.org/10.1016/S0038-0717(02)00258-4

Elefsiniotis, P., \& Li, D. (2006). The effect of temperature and carbon source on denitrification using volatile fatty acids. Biochemical Engineering Journal, 28(2), 148-155. https://doi.org/https://doi.org/10.1016/j.bej.2005.10.004

Fields, S. (2004). Global nitrogen: cycling out of control. Environmental Health Perspectives, 112(10), A556-A563. https://doi.org/10.1289/ehp.112-a556

Finch, H. J. S., Samuel, A. M., \& Lane, G. P. F. (2014). 4 - Fertilisers and manures (Finch, H. J. S., A. M. Samuel, \& G. P. F. B. T.-L. \& W. C. H. I. G. (Ninth E. Lane (eds.); pp. 63-91). Woodhead Publishing. https://doi.org/https://doi.org/10.1533/9781782423928.1.63

Fox, R. H., \& Bandel, V. A. (1989). Dicyandiamide (DCD) research in agriculture in the midAtlantic region. Communications in Soil Science and Plant Analysis, 20(19-20), 1957-1968. https://doi.org/10.1080/00103628909368196

Funk, G. (Water R. B., McClenaghan, W. (Water R. B., \& Holland, C. (Southeastern R. (1980). Water Wells and Ground Water Supplies in Ontario.

Galloway, J. N., Townsend, A. R., Erisman, J. W., Bekunda, M., Cai, Z., Freney, J. R., Martinelli, L. A., Seitzinger, S. P., \& Sutton, M. A. (2008). Transformation of the Nitrogen Cycle: Recent Trends, Questions, and Potential Solutions. Science, 320(5878), 889-892. http://www.jstor.org.proxy.lib.uwaterloo.ca/stable/20054730

Ge, Y., \& Gong, G. (2010). Land surface insulation response to snow depth variability. Journal of Geophysical Research: Atmospheres, https://doi.org/https://doi.org/10.1029/2009JD012798

Gee, G., \& Bauder, J. (1986). Methods of Soil Analysis: Part 1. Physical and Mineralogical Methods. Soil Science Society of America. 
Gentry, L. E., David, M. B., \& McIsaac, G. F. (2014). Variation in Riverine Nitrate Flux and Fall Nitrogen Fertilizer Application in East-Central Illinois. Journal of Environmental Quality, 43(4), $1467-1474$. http://search.proquest.com.proxy.lib.uwaterloo.ca/docview/1550133100?accountid=14906

Gharasoo, M., Ehrl, B. N., Cirpka, O. A., \& Elsner, M. (2019). Modeling of Contaminant Biodegradation and Compound-Specific Isotope Fractionation in Chemostats at Low Dilution Rates. Environmental Science \& Technology, 53(3), 1186-1196. https://doi.org/10.1021/acs.est.8b02498

Gharasoo, M., Thullner, M., \& Elsner, M. (2017). Introduction of a new platform for parameter estimation of kinetically complex environmental systems. Environmental Modelling and Software, 98, 12-20. https://doi.org/10.1016/j.envsoft.2017.09.005

Gioacchini, P., Nastri, A., Marzadori, C., Giovannini, C., Vittori Antisari, L., \& Gessa, C. (2002). Influence of urease and nitrification inhibitors on $\mathrm{N}$ losses from soils fertilized with urea. Biology and Fertility of Soils, 36(2), 129-135. https://doi.org/10.1007/s00374-002-0521-1

Grant, R. F., Lin, S., \& Hernandez-Ramirez, G. (2020). Modelling nitrification inhibitor effects on $\mathrm{N} 2 \mathrm{O}$ emissions after fall- and spring-applied slurry by reducing nitrifier $\mathrm{NH} 4+$ oxidation rate. Biogeosciences, 17(7), 2021-2039. https://doi.org/10.5194/bg-17-2021-2020

Gray, D. M., Toth, B., Zhao, L., Pomeroy, J. W., \& Granger, R. J. (2001). Estimating areal snowmelt infiltration into frozen soils. Hydrological Processes, 15(16), 3095-3111. https://doi.org/10.1002/hyp.320

Green, P. A., Vörösmarty, C. J., Meybeck, M., Galloway, J. N., Peterson, B. J., \& Boyer, E. W. (2004). Pre-Industrial and Contemporary Fluxes of Nitrogen through Rivers: A Global Assessment Based on Typology. Biogeochemistry, 68(1), 71-105. http://www.jstor.org.proxy.lib.uwaterloo.ca/stable/1469864

Groffman, P. M., Butterbach-Bahl, K., Fulweiler, R. W., Gold, A. J., Morse, J. L., Stander, E. K., Tague, C., Tonitto, C., \& Vidon, P. (2009). Challenges to incorporating spatially and temporally explicit phenomena (hotspots and hot moments) in denitrification models. Biogeochemistry, 93(1), 49-77. https://doi.org/10.1007/s10533-008-9277-5

Groffman, P. M., Driscoll, C. T., Fahey, T. J., Hardy, J. P., Fitzhugh, R. D., \& Tierney, G. L. (2001). Effects of mild winter freezing on soil nitrogen and carbon dynamics in a northern hardwood forest. Biogeochemistry, 56(2), 191-213. https://doi.org/10.1023/A:1013024603959

Guardia, G., Marsden, K. A., Vallejo, A., Jones, D. L., \& Chadwick, D. R. (2018). Determining the influence of environmental and edaphic factors on the fate of the nitrification inhibitors 
DCD and DMPP in soil. Science of The Total Environment, 624, 1202-1212. https://doi.org/https://doi.org/10.1016/j.scitotenv.2017.12.250

Guignard, M. S., Leitch, A. R., Acquisti, C., Eizaguirre, C., Elser, J. J., Hessen, D. O., Jeyasingh, P. D., Neiman, M., Richardson, A. E., Soltis, P. S., Soltis, D. E., Stevens, C. J., Trimmer, M., Weider, L. J., Woodward, G., \& Leitch, I. J. (2017). Impacts of Nitrogen and Phosphorus: From Genomes to Natural Ecosystems and Agriculture . In Frontiers in Ecology and Evolution (Vol. 5, p. 70). https://www.frontiersin.org/article/10.3389/fevo.2017.00070

Guntiñas, M. E., Leirós, M. C., Trasar-Cepeda, C., \& Gil-Sotres, F. (2012). Effects of moisture and temperature on net soil nitrogen mineralization: A laboratory study. European Journal of Soil Biology, 48(1), 73-80. https://doi.org/10.1016/j.ejsobi.2011.07.015

Guo, Y. J., Di, H. J., Cameron, K. C., Li, B., Podolyan, A., Moir, J. L., Monaghan, R. M., Smith, L. C., O'Callaghan, M., Bowatte, S., Waugh, D., \& He, J.-Z. (2013). Effect of 7-year application of a nitrification inhibitor, dicyandiamide (DCD), on soil microbial biomass, protease and deaminase activities, and the abundance of bacteria and archaea in pasture soils. Journal of Soils and Sediments, 13(4), 753-759. https://doi.org/10.1007/s11368-012-0646-2

Halvorson, A. D., Snyder, C. S., Blaylock, A. D., \& Del Grosso, S. J. (2014). Enhanced-efficiency nitrogen fertilizers: Potential role in nitrous oxide emission mitigation. Agronomy Journal, 106, 715-722. https://doi.org/10.2134/agronj2013.0081

Hamamoto, T., Uchida, Y., von Rein, I., \& Mukumbuta, I. (2020). Effects of short-term freezing on nitrous oxide emissions and enzyme activities in a grazed pasture soil after bovine-urine application. Science of The Total Environment, 740, 140006. https://doi.org/https://doi.org/10.1016/j.scitotenv.2020.140006

Hansen, J., Sato, M., Ruedy, R., Lo, K., Lea, D. W., \& Medina-Elizade, M. (2006). Global temperature change. Proceedings of the National Academy of Sciences, 103(39), 14288 LP 14293. https://doi.org/10.1073/pnas.0606291103

Hatch, D., Trindade, H., Cardenas, L., Carneiro, J., Hawkins, J., Scholefield, D., \& Chadwick, D. (2005). Laboratory study of the effects of two nitrification inhibitors on greenhouse gas emissions from a slurry-treated arable soil: impact of diurnal temperature cycle. Biology and Fertility of Soils, 41(4), 225-232.

Hatten, J., \& Liles, G. (2019). Chapter 15 - A ‘healthy' balance - The role of physical and chemical properties in maintaining forest soil function in a changing world. In Busse, M., C. P. Giardina, D. M. Morris, \& D. S. B. T.-D. in S. S. Page-Dumroese (Eds.), Global Change and Forest Soils (Vol. 36, pp. 373-396). Elsevier. https://doi.org/https://doi.org/10.1016/B978-0444-63998-1.00015-X 
Hayashi, M. (2013). The Cold Vadose Zone: Hydrological and Ecological Significance of FrozenSoil Processes. Vadose Zone Journal, 12, 1-8. https://doi.org/10.2136/vzj2013.03.0064

Haynes, R. (2005). Labile Organic Matter Fractions as Central Components of the Quality of Agricultural Soils: An Overview. Advances in Agronomy, 85, 221-268. https://doi.org/10.1016/S0065-2113(04)85005-3

Henry, H. A. L. (2007). Soil freeze-thaw cycle experiments: Trends, methodological weaknesses and suggested improvements. In Soil Biology and Biochemistry (pp. 977-986). https://doi.org/10.1016/j.soilbio.2006.11.017

Hentschel, K., Borken, W., \& Matzner, E. (2008). Repeated freeze-thaw events affect leaching losses of nitrogen and dissolved organic matter in a forest soil. Journal of Plant Nutrition and Soil Science, 171(5), 699-706. https://doi.org/10.1002/jpln.200700154

Herrmann, A., \& Witter, E. (2002). Sources of C and N contributing to the flush in mineralization upon freeze-thaw cycles in soils. Soil Biology and Biochemistry, 34(10), 1495-1505. https://doi.org/https://doi.org/10.1016/S0038-0717(02)00121-9

Hoeft, R. G. (1984). Current Status of Nitrification Inhibitor use in U.S. Agriculture. In Nitrogen in Crop Production (pp. https://doi.org/https://doi.org/10.2134/1990.nitrogenincropproduction.c37

Hohmann, M. (1997). Soil freezing - the concept of soil water potential. State of the art. Cold Regions Science and Technology, 25(2), 101-110. https://doi.org/10.1016/s0165$232 \times(96) 00019-5$

Hu, H., Zhang, L., Yuan, C., Zheng, Y., Wang, J., Chen, D., \& He, J. (2015). The large-scale distribution of ammonia oxidizers in paddy soils is driven by soil $\mathrm{pH}$, geographic distance, and climatic factors. In Frontiers in Microbiology (Vol. 6, p. 938). https://www.frontiersin.org/article/10.3389/fmicb.2015.00938

Irigoyen, I., Muro, J., Azpilikueta, M., Aparicio-Tejo, P., \& Lamsfus, C. (2003). Ammonium oxidation kinetics in the presence of nitrification inhibitors DCD and DMPP at various temperatures. Soil Research, 41(6), 1177-1183.

Jarvis, S. C., Stockdale, E. A., Shepherd, M. A., \& Powlson, D. S. (1996). Nitrogen Mineralization in Temperate Agricultural Soils: Processes and Measurement (Sparks, D. L. B. T.-A. in A. (ed.); Vol. 57, pp. 187-235). Academic Press. https://doi.org/https://doi.org/10.1016/S00652113(08)60925-6

Jiang, N., Juan, Y., Tian, L., Chen, X., Sun, W., \& Chen, L. (2018). Modification of the composition of dissolved nitrogen forms, nitrogen transformation processes, and diversity of 
bacterial communities by freeze-thaw events in temperate soils. Pedobiologia, 71, 41-49. https://doi.org/https://doi.org/10.1016/j.pedobi.2018.08.004

Johnston, A. M., \& Bruulsema, T. W. (2014). 4R nutrient stewardship for improved nutrient use efficiency. Procedia Engineering, 365-383. https://doi.org/10.1016/j.proeng.2014.09.029

Kaleem Abbasi, M., Shah, Z., \& Adams, W. A. (2003). Effect of the nitrification inhibitor nitrapyrin on the fate of nitrogen applied to a soil incubated under laboratory conditions. Journal of Plant Nutrition and Soil Science, 166(4), 513-518. https://doi.org/https://doi.org/10.1002/jpln.200320246

Karlen, D. L., Mausbach, M. J., Doran, J. W., Cline, R. G., Harris, R. F., \& Schuman, G. E. (1997). Soil Quality: A Concept, Definition, and Framework for Evaluation (A Guest Editorial). Soil Science Society of America Journal, 61(1), 4-10. https://doi.org/https://doi.org/10.2136/sssaj1997.03615995006100010001x

Keeney, D R, \& Nelson, D. W. (1983). Nitrogen-Inorganic Forms. In Methods of Soil Analysis (pp. 643-698). https://doi.org/https://doi.org/10.2134/agronmonogr9.2.2ed.c33

Keeney, Dennis R. (1980). Factors Affecting the Persistence and Bioactivity of Nitrification Inhibitors. In Nitrification Inhibitors-Potentials and Limitations (pp. 33-46). https://doi.org/https://doi.org/10.2134/asaspecpub38.c3

Keesstra, S. D., Geissen, V., Mosse, K., Piiranen, S., Scudiero, E., Leistra, M., \& van Schaik, L. (2012). Soil as a filter for groundwater quality. In Current Opinion in Environmental Sustainability (pp. 507-516). https://doi.org/10.1016/j.cosust.2012.10.007

Kelliher, F. M., Clough, T. J., Clark, H., Rys, G., \& Sedcole, J. R. (2008). The temperature dependence of dicyandiamide (DCD) degradation in soils: A data synthesis. Soil Biology and Biochemistry, 40(7), 1878-1882. https://doi.org/10.1016/j.soilbio.2008.03.013

Kelso, B. H. L., Smith, R. V, \& Laughlin, R. J. (1999). Effects of Carbon Substrates on Nitrite Accumulation in Freshwater Sediments. Applied and Environmental Microbiology, 65(1), 61 LP - 66. https://doi.org/10.1128/AEM.65.1.61-66.1999

Kim, D.-J., Lee, D.-I., \& Keller, J. (2006). Effect of temperature and free ammonia on nitrification and nitrite accumulation in landfill leachate and analysis of its nitrifying bacterial community by FISH. Bioresource Technology, 97(3), 459-468. https://doi.org/https://doi.org/10.1016/j.biortech.2005.03.032

King, T., Schoenau, J., \& Elliott, J. (2017). Relationship between Manure Management Application Practices and Phosphorus and Nitrogen Export in Snowmelt Run-off Water from a Black Chernozem Saskatchewan Soil. Sustainable Agriculture Research, 6(2), 93-114. 
https://doi.org/10.5539/sar.v6n2p93

Kliewer, B. A., \& Gilliam, J. W. (1995). Water Table Management Effects on Denitrification and Nitrous Oxide Evolution. Soil Science Society of America Journal, 59(6), 1694-1701. https://doi.org/10.2136/sssaj1995.03615995005900060027x

Knapen, A., Poesen, J., Govers, G., Gyssels, G., \& Nachtergaele, J. (2007). Resistance of soils to concentrated flow erosion: A review. Earth-Science Reviews, 80, 75-109. https://doi.org/10.1016/j.earscirev.2006.08.001

Knoepp, J. D., \& Swank, W. T. (2002). Using soil temperature and moisture to predict forest soil nitrogen mineralization. Biology and Fertility of Soils, 36(3), 177-182. https://doi.org/10.1007/s00374-002-0536-7

Knowles, R. (1982). Denitrification. Microbiological Reviews, 46(1), 43-70. https://pubmed.ncbi.nlm.nih.gov/7045624

Krasting, J. P., Broccoli, A. J., Dixon, K. W., \& Lanzante, J. R. (2013). Future Changes in Northern Hemisphere Snowfall. Journal of Climate, 26(20), 7813-7828. https://doi.org/10.1175/JCLID-12-00832.1

Kuzyakov, Y., Friedel, J. K., \& Stahr, K. (2000). Review of mechanisms and quantification of priming effects. Soil Biology and Biochemistry, 32(11), 1485-1498. https://doi.org/https://doi.org/10.1016/S0038-0717(00)00084-5

Lalonde, V., Madramootoo, C. A., Trenholm, L., \& Broughton, R. S. (1996). Effects of controlled drainage on nitrate concentrations in subsurface drain discharge. Agricultural Water Management, 29(2), 187-199. https://doi.org/10.1016/0378-3774(95)01193-5

Larsen, K. S., Jonasson, S., \& Michelsen, A. (2002). Repeated freeze-thaw cycles and their effects on biological processes in two arctic ecosystem types. Applied Soil Ecology, 21(3), 187-195. https://doi.org/https://doi.org/10.1016/S0929-1393(02)00093-8

Lassaletta, L., Billen, G., Grizzetti, B., Garnier, J., Leach, A., \& Galloway, J. (2014). Food and feed trade as a driver in the global nitrogen cycle: 50-year trends. Biogeochemistry, 118. https://doi.org/10.1007/s10533-013-9923-4

Lawrence, D. M., \& Slater, A. G. (2010). The contribution of snow condition trends to future ground climate. Climate Dynamics, 34(7), 969-981. https://doi.org/10.1007/s00382-009$0537-4$

Liu, B., Mørkved, P. T., Frostegård, Å., \& Bakken, L. R. (2010). Denitrification gene pools, 
transcription and kinetics of $\mathrm{NO}, \mathrm{N} 2 \mathrm{O}$ and $\mathrm{N} 2$ production as affected by soil $\mathrm{pH}$. FEMS Microbiology Ecology, 72(3), 407-417. https://doi.org/10.1111/j.1574-6941.2010.00856.x

Liu, R., Hayden, H., Suter, H., He, J., \& Chen, D. (2015). The effect of nitrification inhibitors in reducing nitrification and the ammonia oxidizer population in three contrasting soils. Journal of Soils and Sediments, 15(5), 1113-1118. https://doi.org/10.1007/s11368-015-1086-6

Lubkowski, K., \& Grzmil, B. (2007). Controlled release fertilizers. Polish Journal of Chemical Technology, 9(4), 83-84.

Maag, M., Malinovsky, M., \& Nielsen, S. M. (1997). Kinetics and Temperature Dependence of Potential Denitrification in Riparian Soils. Journal of Environmental Quality, 26(1), 215223. https://doi.org/10.2134/jeq1997.00472425002600010031x

Magalhães, A. M. T., Chalk, P. M., \& Strong, W. M. (1984). Effect of nitrapyrin on nitrous oxide emission from fallow soils fertilized with anhydrous ammonia. Fertilizer Research, 5(4), 411-421. https://doi.org/10.1007/BF01049121

Mahvi, A. H., Nouri, J., Babaei, A. A., \& Nabizadeh, R. (2005). Agricultural activities impact on groundwater nitrate pollution. International Journal of Environmental Science \& Technology, 2(1), 41-47. https://doi.org/10.1007/BF03325856

Major Ions. (2018). Environment and Climate Change Canada. http://donnees.ec.gc.ca/data/air/monitor/monitoring-of-atmospheric-precipitationchemistry/major-ions/

Marozava, S., Meyer, A. H., Pérez-de-Mora, A., Gharasoo, M., Zhuo, L., Wang, H., Cirpka, O. A., Meckenstock, R. U., \& Elsner, M. (2019). Mass Transfer Limitation during Slow Anaerobic Biodegradation of 2-Methylnaphthalene. Environmental Science \& Technology, 53(16), 9481-9490. https://doi.org/10.1021/acs.est.9b01152

Marsden, K. A., Marín-Martínez, A. J., Vallejo, A., Hill, P. W., Jones, D. L., \& Chadwick, D. R. (2016). The mobility of nitrification inhibitors under simulated ruminant urine deposition and rainfall: a comparison between DCD and DMPP. Biology and Fertility of Soils, 52(4), 491503.

Matzner, E., \& Borken, W. (2008). Do freeze-thaw events enhance C and N losses from soils of different ecosystems? A review. In European Journal of Soil Science (pp. 2-22). https://doi.org/10.1111/j.1365-2389.2007.00992.x

McCarty, G. W. (1999). Modes of action of nitrification inhibitors. Biology and Fertility of Soils, 29(1), 1-9. https://doi.org/10.1007/s003740050518 
McCauley, C. A., White, D. M., Lilly, M. R., \& Nyman, D. M. (2002). A comparison of hydraulic conductivities, permeabilities and infiltration rates in frozen and unfrozen soils. Cold Regions Science and Technology, 34(2), 117-125. https://doi.org/https://doi.org/10.1016/S0165232X(01)00064-7

McGeough, K. L., Watson, C. J., Müller, C., Laughlin, R. J., \& Chadwick, D. R. (2016). Evidence that the efficacy of the nitrification inhibitor dicyandiamide (DCD) is affected by soil properties in UK soils. Soil Biology and Biochemistry, 94, 222-232. https://doi.org/https://doi.org/10.1016/j.soilbio.2015.11.017

McKenney, D. J., Johnson, G. P., \& Findlay, W. I. (1984). Effect of Temperature on Consecutive Denitrification Reactions in Brookston Clay and Fox Sandy Loam. Applied and

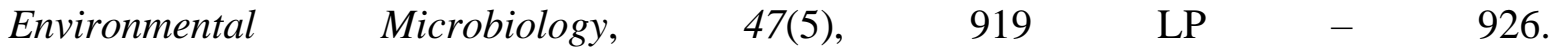
http://aem.asm.org/content/47/5/919.abstract

McTaggart, I. P., Clayton, H., Parker, J., Swan, L., \& Smith, K. A. (1997). Nitrous oxide emissions from grassland and spring barley, following $\mathrm{N}$ fertiliser application with and without nitrification inhibitors. Biology and Fertility of Soils, 25(3), 261-268. https://doi.org/10.1007/s003740050312

Menéndez, S., Barrena, I., Setien, I., González-Murua, C., \& Estavillo, J. M. (2012). Efficiency of nitrification inhibitor DMPP to reduce nitrous oxide emissions under different temperature and moisture conditions. Soil Biology and Biochemistry, 53, 82-89.

Menon, S., Denman, K. L., Brasseur, G., Chidthaisong, A., Ciais, P., Cox, P. M., Dickinson, R. E., Hauglustaine, D., Heinze, C., Holland, E., Jacob, D., Lohmann, U., Ramachandran, S., Leite da Silva Dias, P., Wofsy, S. C., \& Zhang, X. (2007). Couplings between changes in the climate system and biogeochemistry. https://www.osti.gov/biblio/934721

Mikan, C. J., Schimel, J. P., \& Doyle, A. P. (2002). Temperature controls of microbial respiration in arctic tundra soils above and below freezing. Soil Biology and Biochemistry, 34(11), 17851795. https://doi.org/https://doi.org/10.1016/S0038-0717(02)00168-2

Miller, K., Aegerter, B. J., Clark, N. E., Leinfelder-Miles, M., Miyao, E. M., Smith, R., Wilson, R., \& Geisseler, D. (2019). Relationship Between Soil Properties and Nitrogen Mineralization in Undisturbed Soil Cores from California Agroecosystems. Communications in Soil Science and Plant Analysis, 50(1), 77-92. https://doi.org/10.1080/00103624.2018.1554668

Monson, R. K., Lipson, D. L., Burns, S. P., Turnipseed, A. A., Delany, A. C., Williams, M. W., \& Schmidt, S. K. (2006). Winter forest soil respiration controlled by climate and microbial community composition. Nature, 439(7077), 711-714. https://doi.org/10.1038/nature04555

Müller, C., Martin, M., Stevens, R. J., Laughlin, R. J., Kammann, C., Ottow, J. C. G., \& Jäger, H.- 
J. (2002). Processes leading to $\mathrm{N} 2 \mathrm{O}$ emissions in grassland soil during freezing and thawing. Soil Biology and Biochemistry, 34(9), 1325-1331. https://doi.org/https://doi.org/10.1016/S0038-0717(02)00076-7

Murray, E., Roche, P., Briet, M., Moore, B., Morrin, A., Diamond, D., \& Paull, B. (2020). Fully automated, low-cost ion chromatography system for in-situ analysis of nitrite and nitrate in $\begin{array}{llll}\text { natural waters. } & \text { Talanta, } & 216, & \end{array}$ https://doi.org/https://doi.org/10.1016/j.talanta.2020.120955

Nikrad, M. P., Kerkhof, L. J., \& Häggblom, M. M. (2016). The subzero microbiome: Microbial activity in frozen and thawing soils. FEMS Microbiology Ecology, 92(6), 1-16. https://doi.org/10.1093/femsec/fiw081

Norton, J., \& Ouyang, Y. (2019). Controls and Adaptive Management of Nitrification in Agricultural Soils . In Frontiers in Microbiology (Vol. 10, p. 1931). https://www.frontiersin.org/article/10.3389/fmicb.2019.01931

Noxon, J. F. (1976). Atmospheric nitrogen fixation by lightning. Geophysical Research Letters, 3(8), 463-465. https://doi.org/10.1029/g1003i008p00463

Ollivier, J., Töwe, S., Bannert, A., Hai, B., Kastl, E. M., Meyer, A., Su, M. X., Kleineidam, K., \& Schloter, M. (2011). Nitrogen turnover in soil and global change. In FEMS Microbiology Ecology (pp. 3-16). https://doi.org/10.1111/j.1574-6941.2011.01165.x

Ouyang, Y., Evans, S. E., Friesen, M. L., \& Tiemann, L. K. (2018). Effect of nitrogen fertilization on the abundance of nitrogen cycling genes in agricultural soils: A meta-analysis of field studies. Soil Biology and Biochemistry, 127, 71-78. https://doi.org/https://doi.org/10.1016/j.soilbio.2018.08.024

Ouyang, Y., Norton, J., \& Stark, J. (2017). Ammonium availability and temperature control contributions of ammonia oxidizing bacteria and archaea to nitrification in an agricultural soil. Soil Biology and Biochemistry, 113, 161-172. https://doi.org/10.1016/j.soilbio.2017.06.010

Panikov, N. S., Flanagan, P. W., Oechel, W. C., Mastepanov, M. A., \& Christensen, T. R. (2006). Microbial activity in soils frozen to below $-39^{\circ} \mathrm{c}$. Soil Biology and Biochemistry, 38(4), 785794. https://doi.org/10.1016/j.soilbio.2005.07.004

Pankievicz, V. C. S., do Amaral, F. P., Santos, K. F. D. N., Agtuca, B., Xu, Y., Schueller, M. J., Arisi, A. C. M., Steffens, M. B. R., de Souza, E. M., Pedrosa, F. O., Stacey, G., \& Ferrieri, R. A. (2015). Robust biological nitrogen fixation in a model grass-bacterial association. The Plant Journal, 81(6), 907-919. https://doi.org/https://doi.org/10.1111/tpj.12777 
Parkin, T. B. (1987). Soil Microsites as a Source of Denitrification Variability. Soil Science Society of America Journal, 51(5), 1194-1199. https://doi.org/https://doi.org/10.2136/sssaj1987.03615995005100050019x

Parton, W. J., Holland, E. A., Del Grosso, S. J., Hartman, M. D., Martin, R. E., Mosier, A. R., Ojima, D. S., \& Schimel, D. S. (2001). Generalized model for NO x and N2O emissions from soils. Journal of Geophysical Research: Atmospheres, 106(D15), 17403-17419. https://doi.org/https://doi.org/10.1029/2001JD900101

Post, W. M., \& Kwon, K. C. (2000). Soil carbon sequestration and land-use change: Processes and potential. Global Change Biology, 6, 317-327. https://doi.org/10.1046/j.13652486.2000.00308.x

Power, J. F., \& Schepers, J. S. (1989). Nitrate contamination of groundwater in North America. Agriculture, Ecosystems \& Environment, 26(3), 165-187. https://doi.org/https://doi.org/10.1016/0167-8809(89)90012-1

Puttanna, K., Gowda, N. M. N., \& Rao, E. V. S. P. (1999). Effect of concentration, temperature, moisture, liming and organic matter on the efficacy of the nitrification inhibitors benzotriazole, o-nitrophenol, m-nitroaniline and dicyandiamide. Nutrient Cycling in Agroecosystems, 54(3), 251-257.

Quemada, M., Baranski, M., Nobel-de Lange, M. N. J., Vallejo, A., \& Cooper, J. M. (2013). Metaanalysis of strategies to control nitrate leaching in irrigated agricultural systems and their effects on crop yield. Agriculture, Ecosystems \& Environment, 174, 1-10. https://doi.org/https://doi.org/10.1016/j.agee.2013.04.018

Ramirez, K. S., Craine, J. M., \& Fierer, N. (2010). Nitrogen fertilization inhibits soil microbial respiration regardless of the form of nitrogen applied. Soil Biology and Biochemistry, 42(12), 2336-2338. https://doi.org/https://doi.org/10.1016/j.soilbio.2010.08.032

Randall, G. W., \& Vetsch, J. A. (2005). Nitrate Losses in Subsurface Drainage from a CornSoybean Rotation as Affected by Fall and Spring Application of Nitrogen and Nitrapyrin. Journal of Environmental Quality, 34(2), 590-597. https://doi.org/10.2134/jeq2005.0590

Reay, D. S., Davidson, E. A., Smith, K. A., Smith, P., Melillo, J. M., Dentener, F., \& Crutzen, P. J. (2012). Global agriculture and nitrous oxide emissions. Nature Climate Change, 2(6), 410416. https://doi.org/10.1038/nclimate1458

Recio, J., Vallejo, A., Le-Noë, J., Garnier, J., García-Marco, S., Álvarez, J. M., \& Sanz-Cobena, A. (2018). The effect of nitrification inhibitors on NH3 and N2O emissions in highly N fertilized irrigated Mediterranean cropping systems. Science of The Total Environment, 636, 427-436. https://doi.org/https://doi.org/10.1016/j.scitotenv.2018.04.294 
Risk, N., Snider, D., \& Wagner-Riddle, C. (2013). Mechanisms leading to enhanced soil nitrous oxide fluxes induced by freeze-thaw cycles. Canadian Journal of Soil Science, 93, 401-414. https://doi.org/10.4141/cjss2012-071

Rocca, J. D., Hall, E. K., Lennon, J. T., Evans, S. E., Waldrop, M. P., Cotner, J. B., Nemergut, D. R., Graham, E. B., \& Wallenstein, M. D. (2015). Relationships between protein-encoding gene abundance and corresponding process are commonly assumed yet rarely observed. The ISME Journal, 9(8), 1693-1699. https://doi.org/10.1038/ismej.2014.252

Rochette, P., Angers, D. A., Chantigny, M. H., Gasser, M.-O., MacDonald, J. D., Pelster, D. E., \& Bertrand, N. (2013). NH 3 volatilization, soil concentration and soil $\mathrm{pH}$ following subsurface banding of urea at increasing rates. Canadian Journal of Soil Science, 93, 261-268. https://doi.org/10.4141/cjss2012-095

Romero, C. M., Engel, R. E., Chen, C., Wallander, R., \& Jones, C. A. (2017). Late-Fall, Winter, and Spring Broadcast Applications of Urea to No-Till Winter Wheat II. Fertilizer N recovery, Yield, and Protein as Affected by NBPT. Soil Science Society of America Journal, 81(2), 331-340. https://doi.org/10.2136/sssaj2016.10.0333

Ros, G. H. (2012). Predicting soil N mineralization using organic matter fractions and soil properties: A re-analysis of literature data. Soil Biology and Biochemistry, 45, 132-135. https://doi.org/https://doi.org/10.1016/j.soilbio.2011.10.015

Ruser, R., Flessa, H., Russow, R., Schmidt, G., Buegger, F., \& Munch, J. C. (2006). Emission of $\mathrm{N} 2 \mathrm{O}, \mathrm{N} 2$ and $\mathrm{CO} 2$ from soil fertilized with nitrate: effect of compaction, soil moisture and rewetting. Soil Biology and Biochemistry, 38(2), 263-274. https://doi.org/https://doi.org/10.1016/j.soilbio.2005.05.005

Ryan, M. C., Kachanoski, R. G., \& Gillham, R. W. (2000). Overwinter soil nitrogen dynamics in seasonally frozen soils. Canadian Journal of Soil Science, 80(4), 541-550. https://doi.org/10.4141/S99-017

Saad, O. A. L. O., \& Conrad, R. (1993). Temperature dependence of nitrification, denitrification, and turnover of nitric oxide in different soils. Biology and Fertility of Soils, 15(1), 21-27. https://doi.org/10.1007/BF00336283

Saadat, S., Bowling, L., Frankenberger, J., \& Kladivko, E. (2018). Nitrate and phosphorus transport through subsurface drains under free and controlled drainage. Water Research, 142, 196-207. https://doi.org/https://doi.org/10.1016/j.watres.2018.05.040

Sahrawat, K. L. (2008). Factors affecting nitrification in soils. Communications in Soil Science and Plant Analysis, 39, 1436-1446. https://doi.org/10.1080/00103620802004235 
Schimel, J. P., \& Clein, J. S. (1996). Microbial response to freeze-thaw cycles in tundra and taiga soils. Soil Biology and Biochemistry, 28(8), 1061-1066. https://doi.org/https://doi.org/10.1016/0038-0717(96)00083-1

Schleper, C., \& Nicol, G. W. (2010). Ammonia-Oxidising Archaea - Physiology, Ecology and Evolution (Poole, R. K. B. T.-A. in M. P. (Ed.); Vol. 57, pp. 1-41). Academic Press. https://doi.org/https://doi.org/10.1016/B978-0-12-381045-8.00001-1

Schlesinger, W. H. (2009). On the fate of anthropogenic nitrogen. Proceedings of the National Academy of Sciences, 106(1), 203 LP - 208. https://doi.org/10.1073/pnas.0810193105

Schlüter, S., Henjes, S., Zawallich, J., Bergaust, L., Horn, M., Ippisch, O., Vogel, H.-J., \& Dörsch, P. (2018). Denitrification in Soil Aggregate Analogues-Effect of Aggregate Size and Oxygen Diffusion . In Frontiers in Environmental Science (Vol. 6, p. 17). https://www.frontiersin.org/article/10.3389/fenvs.2018.00017

Shammas, N. K. (1986). Interactions of Temperature, $\mathrm{pH}$, and Biomass on the Nitrification Process. Journal (Water Pollution Control Federation), 58(1), 52-59. http://www.jstor.org/stable/25042841

Shapleigh, J. P. (2009). Dissimilatory and Assimilatory Nitrate Reduction in the Purple Photosynthetic Bacteria (pp. 623-642). Springer Netherlands. https://doi.org/10.1007/978-14020-8815-5_31

Sharpley, A., Weld, J., Beegle, D., Kleinman, P., Gburek, W., Moore, P., \& Mullins, G. (2003). Development of Phosphorus Indices for Nutrient Management Planning Strategies in the United States. Journal of Soil and Water Conservation, 58(3), 137.

Shaviv, A., \& Mikkelsen, R. L. (1993). Controlled-release fertilizers to increase efficiency of nutrient use and minimize environmental degradation - A review. Fertilizer Research, 35(1), 1-12. https://doi.org/10.1007/BF00750215

Sigurdarson, J. J., Svane, S., \& Karring, H. (2018). The molecular processes of urea hydrolysis in relation to ammonia emissions from agriculture. Reviews in Environmental Science and Bio/Technology, 17(2), 241-258. https://doi.org/10.1007/s11157-018-9466-1

Singh, P., Wu, J. Q., McCool, D. K., Dun, S., Lin, C.-H., \& Morse, J. R. (2009). Winter Hydrologic and Erosion Processes in the U.S. Palouse Region: Field Experimentation and WEPP Simulation. Vadose Zone Journal, 8(2), 426-436. https://doi.org/10.2136/vzj2008.0061

Singh, R. P., Kumar, M., \& Jaiwal, P. K. (2008). Improvement in nitrogen use efficiency and yield of crop plants by sustained nutrient supply and enhanced nitrogen assimilation. Development in Physiology, Biochemistry and Molecular Biology of Plants, 1-31. 
Skiba, U. (2008). Denitrification (Jørgensen, S. E. \& B. D. B. T.-E. of E. Fath (Eds.); pp. 866871). Academic Press. https://doi.org/https://doi.org/10.1016/B978-008045405-4.00264-0

Smith, Cotrufo, M. F., Rumpel, C., Paustian, K., Kuikman, P. J., Elliott, J. A., McDowell, R., Griffiths, R. I., Asakawa, S., Bustamante, M., House, J. I., Sobocká, J., Harper, R., Pan, G., West, P. C., Gerber, J. S., Clark, J. M., Adhya, T., Scholes, R. J., \& Scholes, M. C. (2015). Biogeochemical cycles and biodiversity as key drivers of ecosystem services provided by soils. SOIL, 1, 665-685. https://doi.org/10.5194/soil-1-665-2015

Smith, M. S., \& Tiedje, J. M. (1979). Phases of denitrification following oxygen depletion in soil. Soil Biology and Biochemistry, 11(3), 261-267.

Smolders, A. J. P., Lucassen, E. C. H. E. T., Bobbink, R., Roelofs, J. G. M., \& Lamers, L. P. M. (2010). How nitrate leaching from agricultural lands provokes phosphate eutrophication in groundwater fed wetlands: the sulphur bridge. Biogeochemistry, 98(1), 1-7. https://doi.org/10.1007/s10533-009-9387-8

Soares, J. R., Cassman, N. A., Kielak, A. M., Pijl, A., Carmo, J. B., Lourenço, K. S., Laanbroek, H. J., Cantarella, H., \& Kuramae, E. E. (2016). Nitrous oxide emission related to ammoniaoxidizing bacteria and mitigation options from $\mathrm{N}$ fertilization in a tropical soil. Scientific Reports, 6(1), 30349. https://doi.org/10.1038/srep30349

Song, Y., Zou, Y., Wang, G., \& Yu, X. (2017). Altered soil carbon and nitrogen cycles due to the freeze-thaw effect: A meta-analysis. Soil Biology and Biochemistry, 109, 35-49. https://doi.org/10.1016/j.soilbio.2017.01.020

Stadler, D., Stahli, M., Aeby, P., \& Fluhler, H. (2000). Dye Tracing and Image Analysis for Quantifying Water Infiltration into Frozen Soils. Soil Science Society of America Journal, 64(2), 505-516. https://doi.org/10.2136/sssaj2000.642505x

Stevenson, F. J. (1982). Organic Forms of Soil Nitrogen. In Nitrogen in Agricultural Soils (pp. 67-122). https://doi.org/https://doi.org/10.2134/agronmonogr22.c3

Swerts, M., Merckx, R., \& Vlassak, K. (1996). Denitrification, N2-fixation and fermentation during anaerobic incubation of soils amended with glucose and nitrate. Biology and Fertility of Soils, 23(3), 229-235. https://doi.org/10.1007/BF00335949

Taylor, A. E., Giguere, A. T., Zoebelein, C. M., Myrold, D. D., \& Bottomley, P. J. (2017). Modeling of soil nitrification responses to temperature reveals thermodynamic differences between ammonia-oxidizing activity of archaea and bacteria. The ISME Journal, 11(4), 896908. https://doi.org/10.1038/ismej.2016.179

Thapa, R., Chatterjee, A., Awale, R., McGranahan, D. A., \& Daigh, A. (2016). Effect of Enhanced 
Efficiency Fertilizers on Nitrous Oxide Emissions and Crop Yields: A Meta-analysis. Soil Science Society of America Journal, 80(5), 1121-1134. https://doi.org/10.2136/sssaj2016.06.0179

Torbert, H. A., \& Wood, C. W. (1992). Effects of soil compaction and water-filled pore space on soil microbial activity and $\mathrm{N}$ losses. Communications in Soil Science and Plant Analysis, 23(11-12), 1321-1331. https://doi.org/10.1080/00103629209368668

Tourna, M., Freitag, T. E., Nicol, G. W., \& Prosser, J. I. (2008). Growth, activity and temperature responses of ammonia-oxidizing archaea and bacteria in soil microcosms. Environmental Microbiology, 10(5), 1357-1364.

Van Bochove, E., Thériault, G., Rochette, P., Jones, H. G., \& Pomeroy, J. W. (2001). Thick ice layers in snow and frozen soil affecting gas emissions from agricultural soils during winter. Journal of Geophysical Research Atmospheres, 106, 23061-23071. https://doi.org/10.1029/2000JD000044

Velthof, G. L., Oudendag, D., Witzke, H. P., Asman, W. A. H., Klimont, Z., \& Oenema, O. (2009). Integrated Assessment of Nitrogen Losses from Agriculture in EU-27 using MITERRAEUROPE. Journal of Environmental Quality, 38(2), 402-417. https://doi.org/10.2134/jeq2008.0108

Vigil, M. F., Eghball, B., Cabrera, M. L., Jakubowski, B. R., \& Davis, J. G. (2002). Accounting for seasonal nitrogen mineralization: An overview. Journal of Soil and Water Conservation, 57(6), 464 LP - 469. http://www.jswconline.org/content/57/6/464.abstract

Vitousek, P. M., Aber, J. D., Howarth, R. W., Likens, G. E., Matson, P. A., Schindler, D. W., Schlesinger, W. H., \& Tilman, D. G. (1997). HUMAN ALTERATION OF THE GLOBAL NITROGEN CYCLE: SOURCES AND CONSEQUENCES. Ecological Applications, 7(3), 737-750. 0761(1997)007[0737:HAOTGN]2.0.CO;2 https://doi.org/https://doi.org/10.1890/1051-

Wagner-Riddle, C., Hu, Q. C., van Bochove, E., \& Jayasundara, S. (2008a). Linking Nitrous Oxide Flux During Spring Thaw to Nitrate Denitrification in the Soil Profile. Soil Science Society of America Journal, 72, 908-916. https://doi.org/10.2136/sssaj2007.0353

Wagner-Riddle, C., Hu, Q. C., van Bochove, E., \& Jayasundara, S. (2008b). Linking Nitrous Oxide Flux During Spring Thaw to Nitrate Denitrification in the Soil Profile. Soil Science Society of America Journal, 72, 908-916. https://doi.org/10.2136/sssaj2007.0353

Wagner-Riddle, Claudia, Congreves, K. A., Abalos, D., Berg, A. A., Brown, S. E., Ambadan, J. T., Gao, X., \& Tenuta, M. (2017). Globally important nitrous oxide emissions from croplands induced by freeze-thaw cycles. Nature Geoscience, 10, 279-283. 
https://doi.org/10.1038/ngeo2907

Waley, S. G. (1985). Kinetics of suicide substrates. Practical procedures for determining parameters. The Biochemical Journal, 227(3), 843-849. https://doi.org/10.1042/bj2270843

Walker, J. K. M., Egger, K. N., \& Henry, G. H. R. (2008). Long-term experimental warming alters nitrogen-cycling communities but site factors remain the primary drivers of community structure in high arctic tundra soils. The ISME Journal, 2(9), 982-995. https://doi.org/10.1038/ismej.2008.52

Watanabe, K., \& Flury, M. (2008). Capillary bundle model of hydraulic conductivity for frozen soil. Water Resources Research, 44(12). https://doi.org/https://doi.org/10.1029/2008WR007012

Watanabe, T., Tateno, R., Imada, S., Fukuzawa, K., Isobe, K., Urakawa, R., Oda, T., Hosokawa, N., Sasai, T., Inagaki, Y., Hishi, T., Toda, H., \& Shibata, H. (2019). The effect of a freezethaw cycle on dissolved nitrogen dynamics and its relation to dissolved organic matter and soil microbial biomass in the soil of a northern hardwood forest. Biogeochemistry, 142(3), 319-338. https://doi.org/10.1007/s10533-019-00537-w

Wertz, S., Goyer, C., Zebarth, B. J., Burton, D. L., Tatti, E., Chantigny, M. H., \& Filion, M. (2013). Effects of temperatures near the freezing point on $\mathrm{N} 2 \mathrm{O}$ emissions, denitrification and on the abundance and structure of nitrifying and denitrifying soil communities. FEMS Microbiology Ecology, 83(1), 242-254. https://doi.org/10.1111/j.1574-6941.2012.01468.x

White, P. J., \& Broadley, M. R. (2001). Chloride in soils and its uptake and movement within the plant: A review. In Annals of Botany (pp. 967-988). https://doi.org/10.1006/anbo.2001.1540

Wipf, S., Sommerkorn, M., Stutter, M. I., Wubs, E. R. J., Van Der Wal, R., \& Barger, N. (2015). Snow cover, freeze-thaw, and the retention of nutrients in an oceanic mountain ecosystem. Ecosphere, 6, 1-16. https://doi.org/10.1890/ES15-00099.1

Wong, M. T. F., \& Nortcliff, S. (1995). Seasonal fluctuations of native available N and soil management implications. Fertilizer Research, 42(1), 13-26. https://doi.org/10.1007/BF00750496

Yanai, Y., Toyota, K., \& Okazaki, M. (2004). Effects of successive soil freeze-thaw cycles on nitrification potential of soils. Soil Science and Plant Nutrition, 50(6), 831-837. https://doi.org/10.1080/00380768.2004.10408543

Yang, M., Fang, Y., Sun, D., \& Shi, Y. (2016). Efficiency of two nitrification inhibitors (dicyandiamide and 3, 4-dimethypyrazole phosphate) on soil nitrogen transformations and plant productivity: a meta-analysis. Scientific Reports, 6(1), 22075. 
https://doi.org/10.1038/srep22075

Zacherl, B., \& Amberger, A. (1990). Effect of the nitrification inhibitors dicyandiamide, nitrapyrin and thiourea onNitrosomonas europaea. Fertilizer Research, 22(1), 37-44. https://doi.org/10.1007/BF01054805

Zaman, M., Saggar, S., Blennerhassett, J. D., \& Singh, J. (2009). Effect of urease and nitrification inhibitors on $\mathrm{N}$ transformation, gaseous emissions of ammonia and nitrous oxide, pasture yield and N uptake in grazed pasture system. Soil Biology and Biochemistry, 41(6), 12701280. https://doi.org/https://doi.org/10.1016/j.soilbio.2009.03.011

Zhang, T. (2005). Influence of the seasonal snow cover on the ground thermal regime: An overview. In Reviews of Geophysics (pp. 1-23). https://doi.org/10.1029/2004RG000157

Zhang, X., Vincent, L. A., Hogg, W. D., \& Niitsoo, A. (2000). Temperature and precipitation trends in Canada during the 20th century. Atmosphere-Ocean, 38(3), 395-429. https://doi.org/10.1080/07055900.2000.9649654

Zhang, Y., \& Ma, N. (2018). Spatiotemporal variability of snow cover and snow water equivalent in the last three decades over Eurasia. Journal of Hydrology, 559, 238-251. https://doi.org/10.1016/j.jhydrol.2018.02.031

Zhou, W., Chen, H., Zhou, L., Lewis, B. J., Ye, Y., Tian, J., Li, G., \& Dai, L. (2011). Effect of freezing-thawing on nitrogen mineralization in vegetation soils of four landscape zones of Changbai Mountain. Annals of Forest Science, 68(5), 943-951. https://doi.org/10.1007/s13595-011-0100-4

Zhou, Y., Hartemink, A. E., Shi, Z., Liang, Z., \& Lu, Y. (2019). Land use and climate change effects on soil organic carbon in North and Northeast China. Science of the Total Environment, 647, 1230-1238. https://doi.org/10.1016/j.scitotenv.2018.08.016

Zumft, W. G. (1997). Cell biology and molecular basis of denitrification. Microbiology and Molecular Biology Reviews, 61(4), $533 \quad$ LP $\quad-616$. $\mathrm{http}: / / \mathrm{mmbr}$.asm.org/content/61/4/533.abstract 


\section{Appendix: Additional Experimental Information and Results from Chapters 2 and 3}

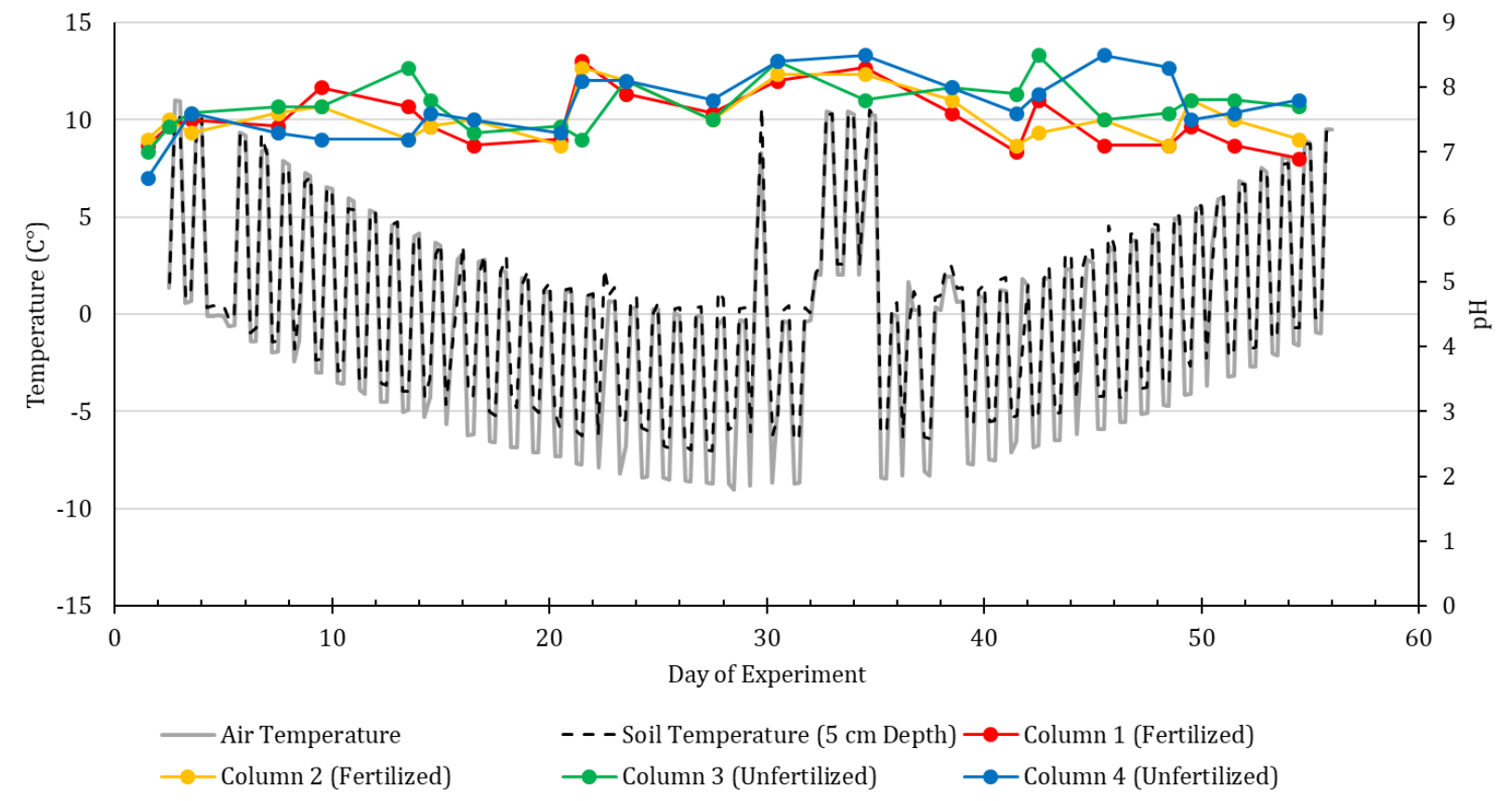

Figure A-1: Temperature and leachate $\mathrm{pH}$ versus time for fertilized and unfertilized columns presented in Chapter 2. 
Freeze

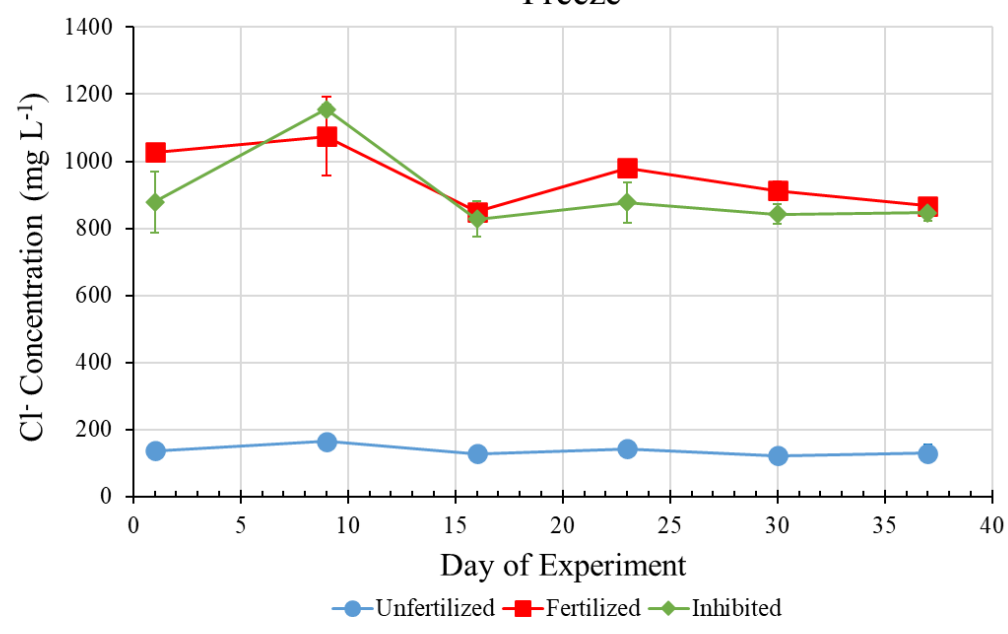

Thaw

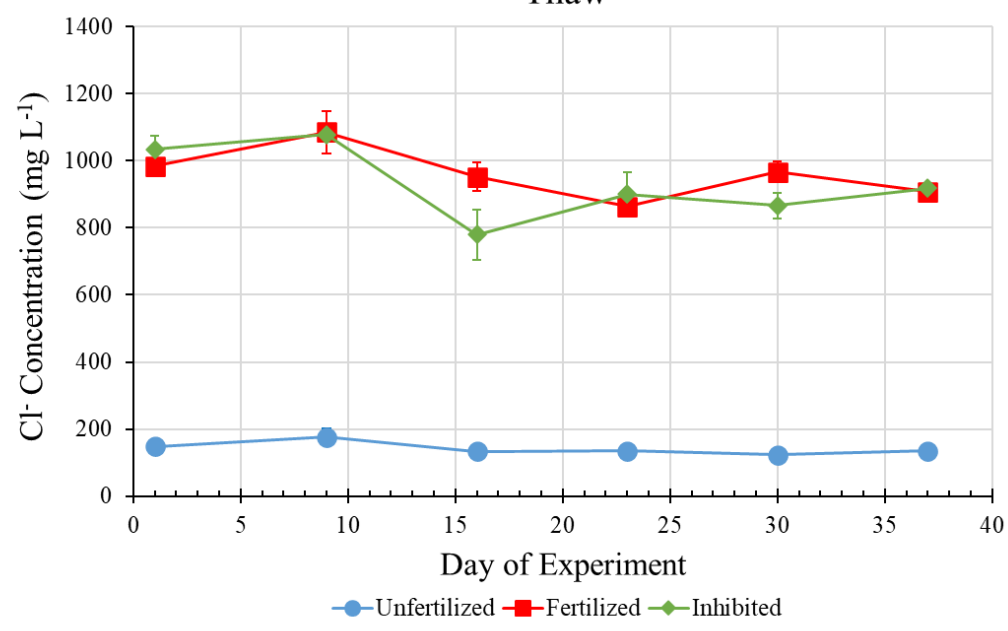

FTC

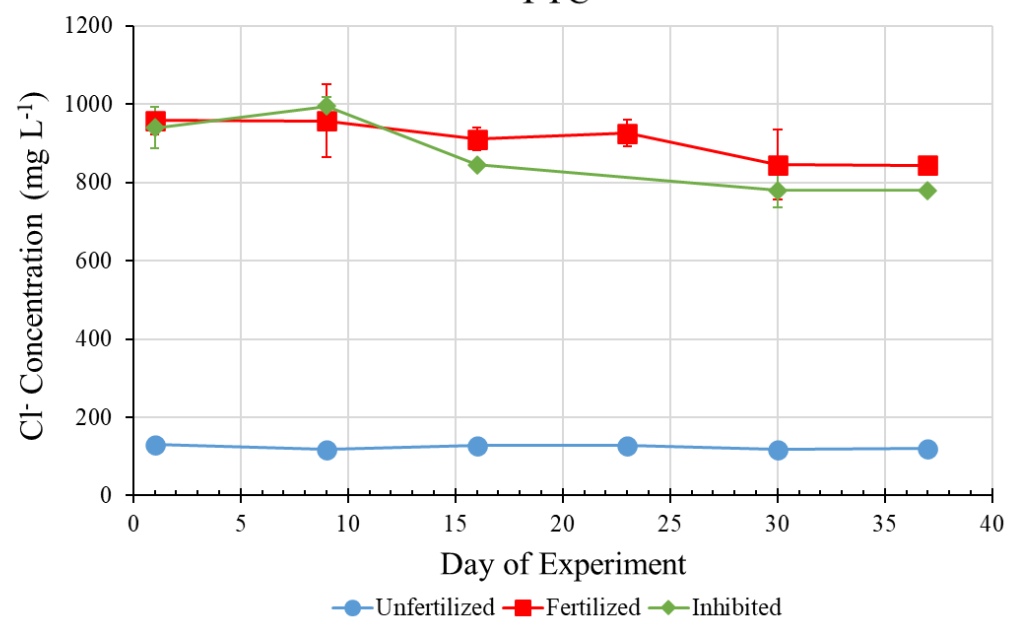

Figure A-2: Chloride $\left(\mathrm{Cl}^{-}\right)$concentrations versus time for unfertilized, fertilized, and inhibited soil samples under freeze $\left(-10^{\circ} \mathrm{C}\right)$, thaw $\left(4^{\circ} \mathrm{C}\right)$, and freeze-thaw cycle (FTC) (between $-10^{\circ} \mathrm{C}$ and $4^{\circ} \mathrm{C}$ ) conditions presented in Chapter 3. 

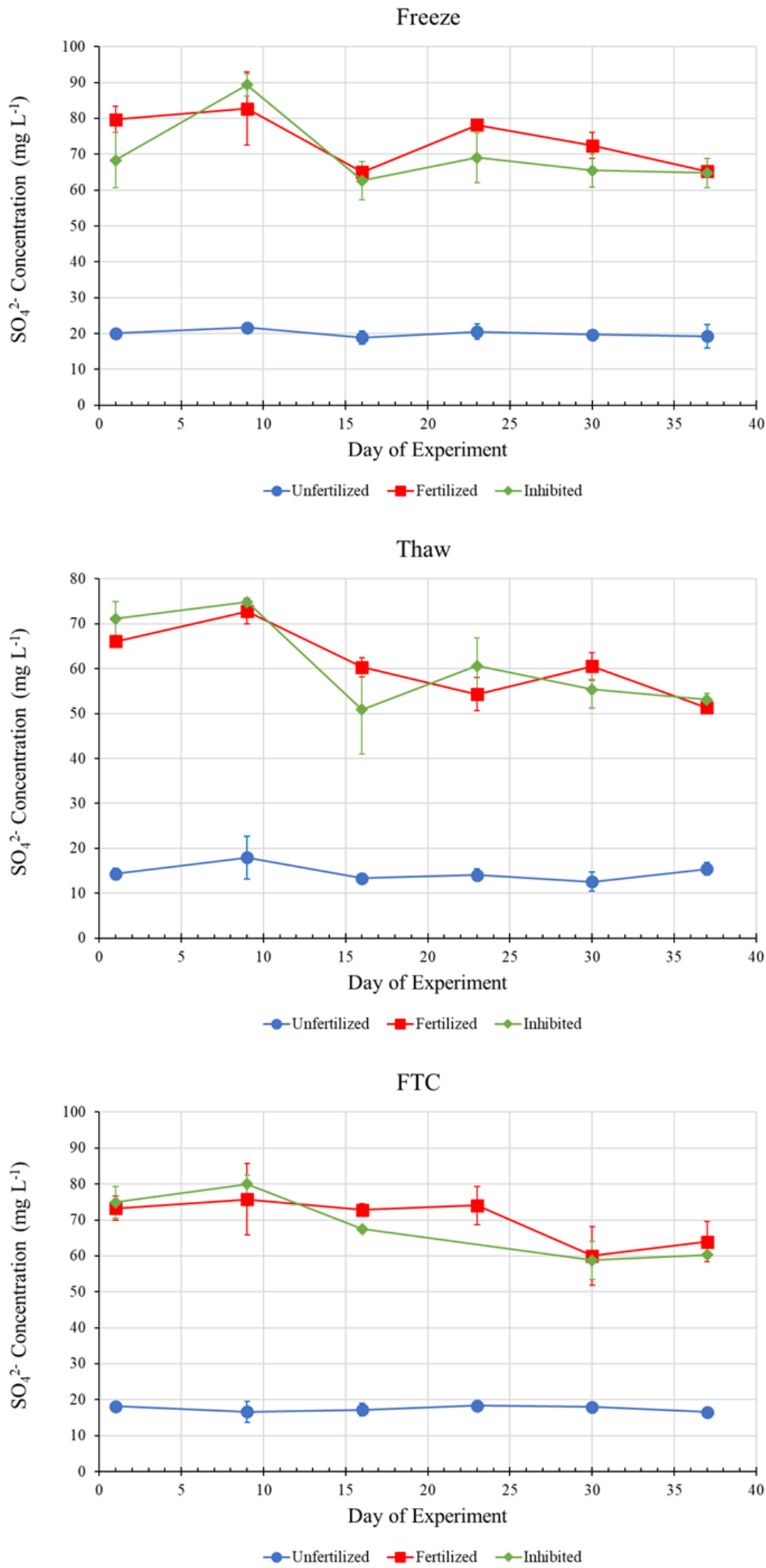

Figure A-3: Sulfate $\left(\mathrm{SO}_{4}{ }^{2-}\right)$ concentrations versus time for unfertilized, fertilized, and inhibited soil samples under freeze $\left(-10^{\circ} \mathrm{C}\right)$, thaw $\left(4^{\circ} \mathrm{C}\right)$, and freeze-thaw cycle $(\mathrm{FTC})$ (between $-10^{\circ} \mathrm{C}$ and $\left.4^{\circ} \mathrm{C}\right)$ conditions presented in Chapter 3. 
Freeze

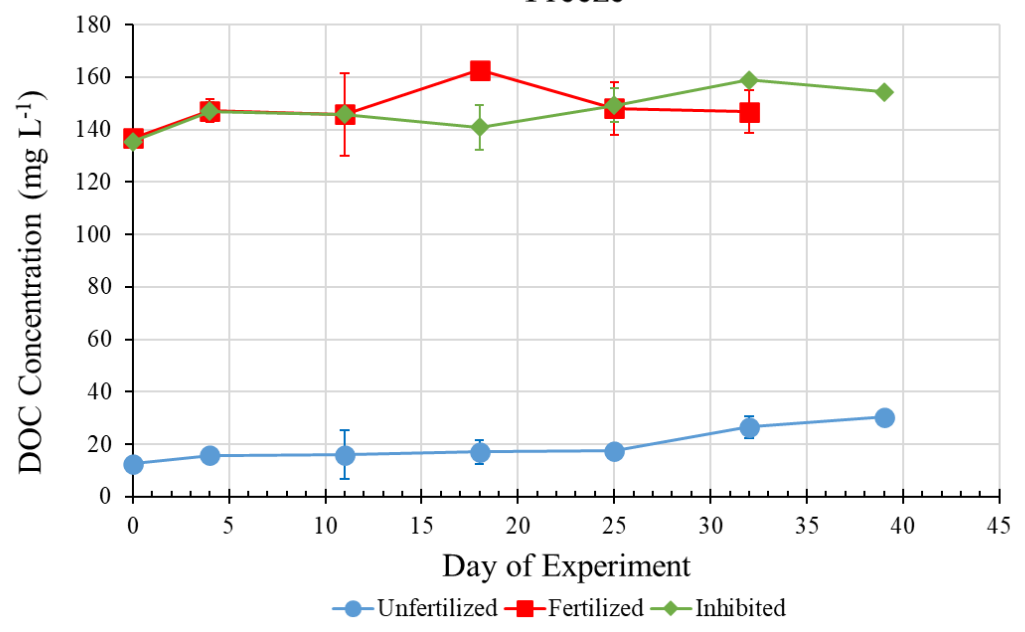

Thaw

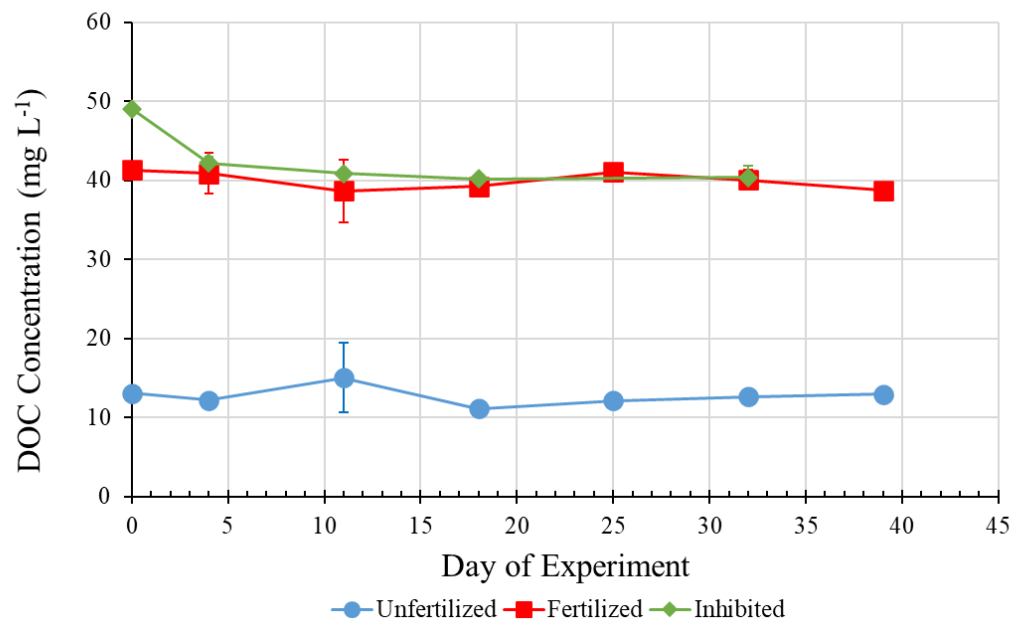

FTC

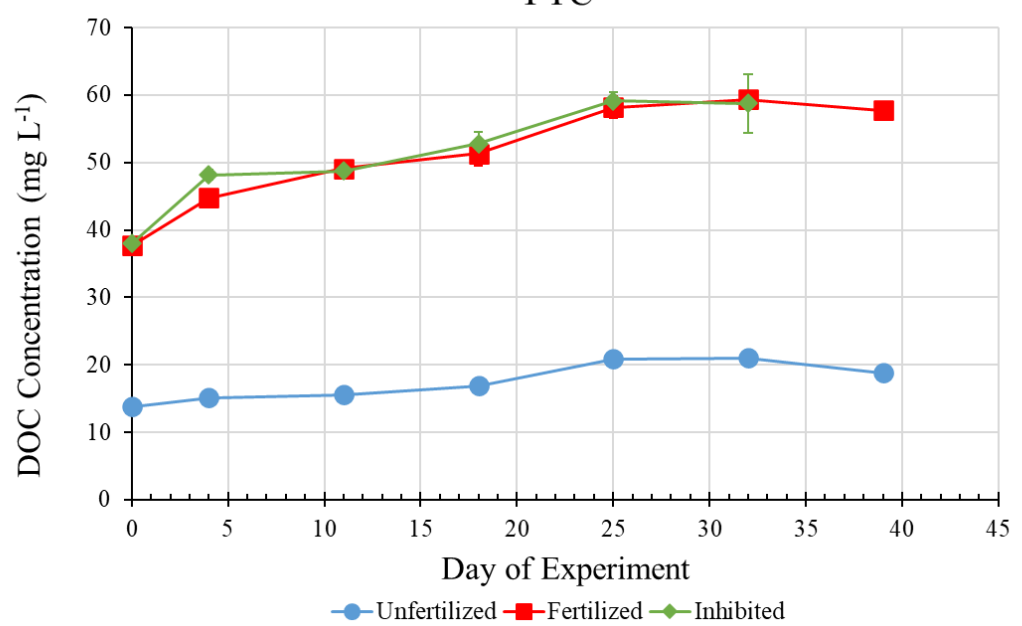

Figure A-4: Dissolved organic carbon (DOC) concentrations versus time for unfertilized, fertilized, and inhibited soil samples under freeze $\left(-10^{\circ} \mathrm{C}\right)$, thaw $\left(4^{\circ} \mathrm{C}\right)$, and freeze-thaw cycle (FTC) (between $-10^{\circ} \mathrm{C}$ and $4^{\circ} \mathrm{C}$ ) conditions presented in Chapter 3 . 
Freeze
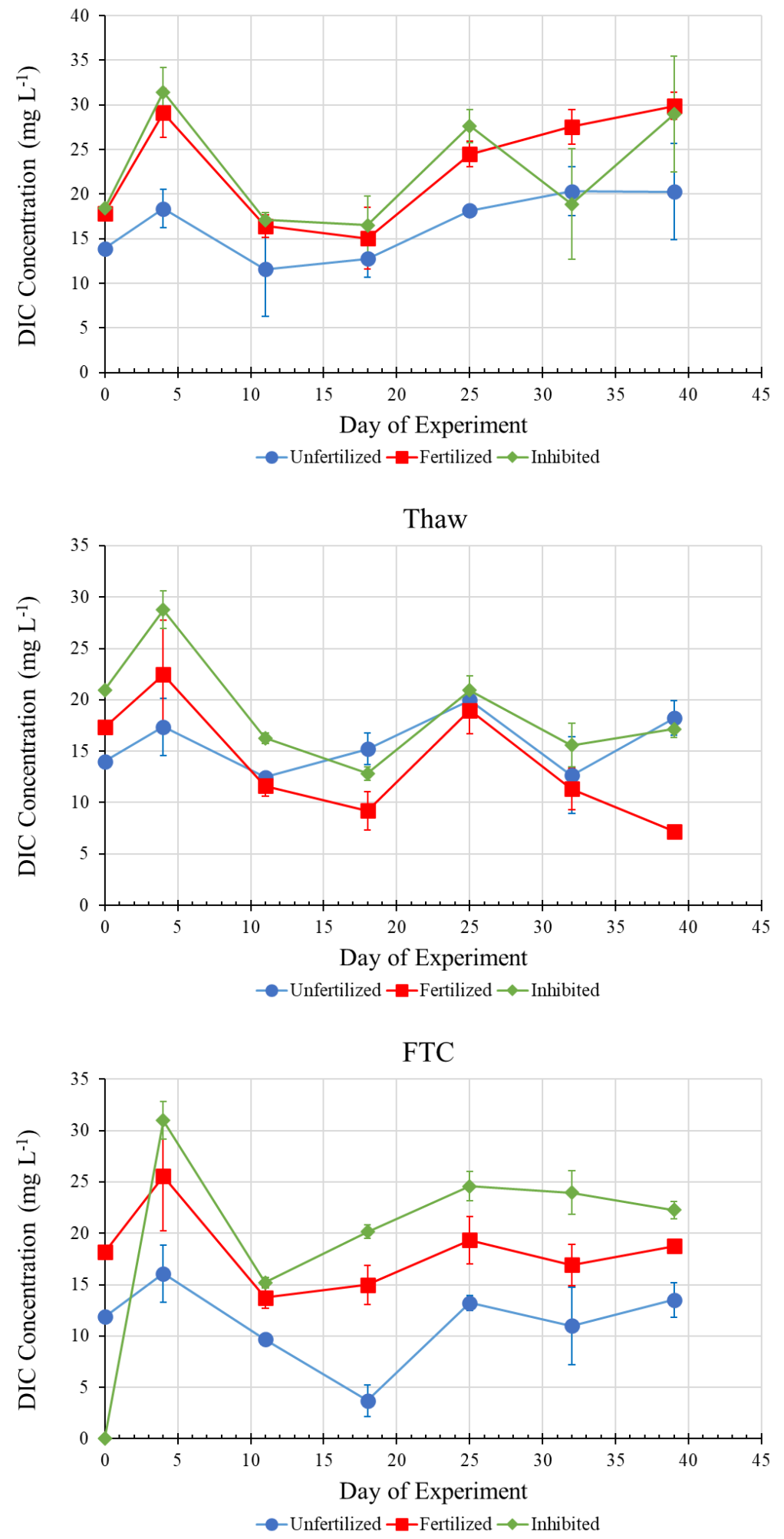

Figure A-5: Dissolved inorganic carbon (DIC) concentrations versus time for unfertilized, fertilized, and inhibited soil samples under freeze $\left(-10^{\circ} \mathrm{C}\right)$, thaw $\left(4^{\circ} \mathrm{C}\right)$, and freeze-thaw cycle (FTC) (between $-10^{\circ} \mathrm{C}$ and $4^{\circ} \mathrm{C}$ ) conditions presented in Chapter 3. 
Freeze

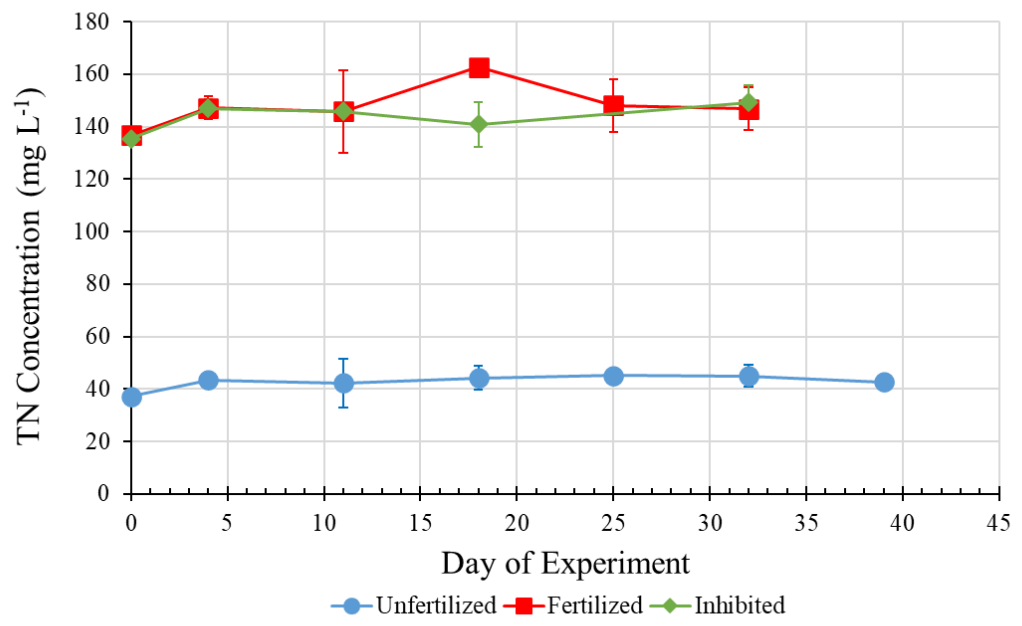

Thaw

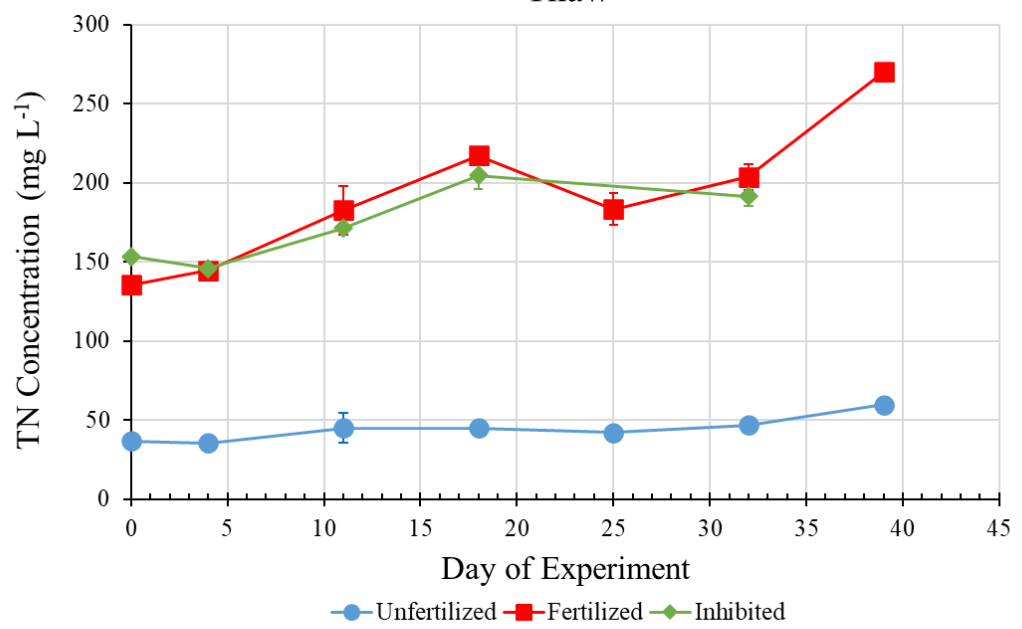

FTC

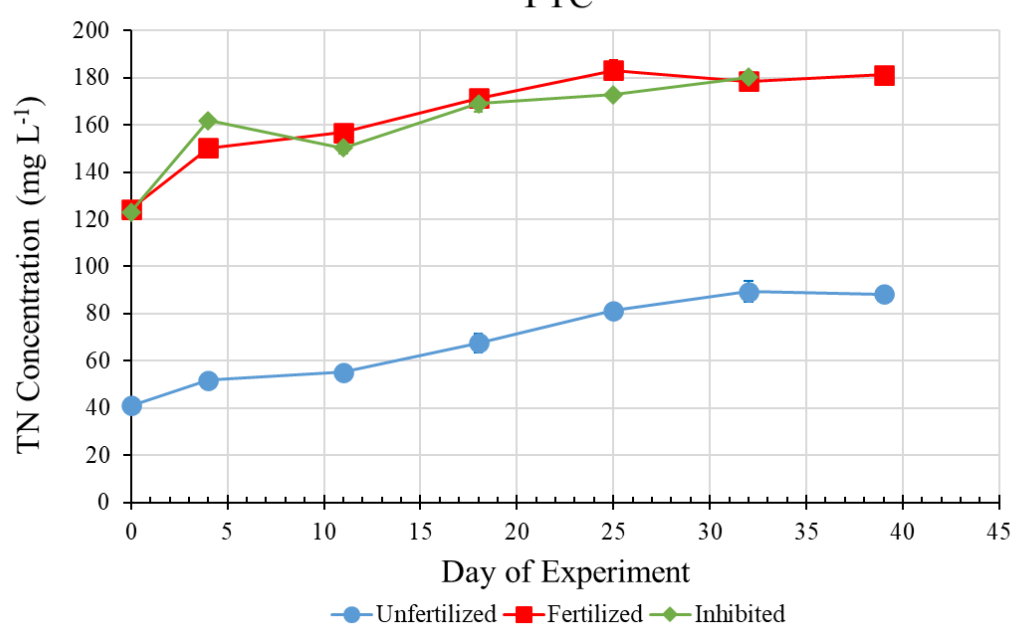

Figure A-6: Total nitrogen (TN) concentrations versus time for unfertilized, fertilized, and inhibited soil samples under freeze $\left(-10^{\circ} \mathrm{C}\right)$, thaw $\left(4^{\circ} \mathrm{C}\right)$, and freeze-thaw cycle (FTC) (between $10^{\circ} \mathrm{C}$ and $4^{\circ} \mathrm{C}$ ) conditions presented in Chapter 3 . 
Table A-1: Tables showing water-filled pore space values across depth for the soil columns presented in the Chapter 2.

\begin{tabular}{|c|c|c|c|c|c|}
\hline & \multicolumn{5}{|c|}{ Fertilized Column 1} \\
\hline Day & $\begin{array}{l}5.7 \mathrm{~cm} \\
\text { Depth }\end{array}$ & $\begin{array}{c}11.8 \mathrm{~cm} \\
\text { Depth }\end{array}$ & $\begin{array}{c}17.7 \mathrm{~cm} \\
\text { Depth }\end{array}$ & $\begin{array}{c}26.5 \mathrm{~cm} \\
\text { Depth }\end{array}$ & $\begin{array}{c}38.3 \mathrm{~cm} \\
\text { Depth }\end{array}$ \\
\hline 1 & 41.83 & 48.40 & 46.35 & 50.55 & 53.99 \\
\hline 8 & 44.74 & 45.96 & 50.80 & 48.47 & 47.55 \\
\hline 15 & 41.12 & 43.88 & 48.38 & 44.18 & 56.84 \\
\hline 22 & 47.59 & 47.82 & 53.99 & 53.27 & 50.30 \\
\hline 29 & 52.65 & 54.21 & 58.65 & 55.14 & 93.28 \\
\hline 34 & 50.71 & 53.85 & 52.81 & 54.69 & 56.70 \\
\hline 36 & 49.44 & 49.81 & 53.90 & 54.15 & 69.68 \\
\hline 44 & 51.57 & 49.58 & 50.44 & 51.57 & 53.47 \\
\hline 50 & 50.71 & 48.43 & 48.83 & 50.46 & 49.65 \\
\hline \multirow[t]{2}{*}{57} & 47.07 & 50.24 & 51.98 & 51.95 & 50.33 \\
\hline & \multicolumn{5}{|c|}{ Fertilized Column 2} \\
\hline Day & $\begin{array}{l}5.7 \mathrm{~cm} \\
\text { Depth }\end{array}$ & $\begin{array}{c}11.8 \mathrm{~cm} \\
\text { Depth }\end{array}$ & $\begin{array}{c}17.7 \mathrm{~cm} \\
\text { Depth }\end{array}$ & $\begin{array}{c}26.5 \mathrm{~cm} \\
\text { Depth }\end{array}$ & $\begin{array}{c}38.3 \mathrm{~cm} \\
\text { Depth }\end{array}$ \\
\hline 1 & 52.18 & 52.32 & 54.67 & 55.98 & 58.76 \\
\hline 8 & 46.44 & 47.66 & 53.54 & 49.33 & 52.54 \\
\hline 15 & 45.60 & 50.37 & 46.10 & 49.99 & 54.73 \\
\hline 22 & 48.11 & 45.71 & 50.05 & 50.37 & 50.55 \\
\hline 29 & 55.71 & 59.03 & 64.50 & 74.29 & 65.34 \\
\hline 34 & 48.38 & 49.01 & 49.72 & 54.33 & 55.28 \\
\hline 36 & 49.42 & 46.62 & 48.92 & 51.07 & 52.02 \\
\hline 44 & 48.47 & 48.38 & 48.52 & 48.47 & 47.43 \\
\hline 50 & 49.29 & 48.07 & 46.89 & 47.05 & 47.39 \\
\hline 57 & 43.72 & 46.14 & 47.25 & 51.37 & 50.48 \\
\hline
\end{tabular}


Table A-1 (continued)

\begin{tabular}{|c|c|c|c|c|c|}
\hline \multirow[b]{2}{*}{ Day } & \multicolumn{5}{|c|}{ Unfertilized Column 3} \\
\hline & $\begin{array}{l}5.7 \mathrm{~cm} \\
\text { Depth }\end{array}$ & $\begin{array}{l}11.8 \mathrm{~cm} \\
\text { Depth }\end{array}$ & $\begin{array}{c}17.7 \mathrm{~cm} \\
\text { Depth }\end{array}$ & $\begin{array}{c}26.5 \mathrm{~cm} \\
\text { Depth }\end{array}$ & $\begin{array}{c}38.3 \mathrm{~cm} \\
\text { Depth }\end{array}$ \\
\hline 1 & 44.92 & 51.68 & 48.65 & 80.33 & 37.76 \\
\hline 8 & 46.19 & 51.82 & 54.37 & 48.86 & 51.03 \\
\hline 15 & 44.09 & 49.11 & 47.75 & 51.21 & 56.97 \\
\hline 22 & 47.43 & 49.56 & 46.21 & 48.00 & 56.43 \\
\hline 29 & 51.84 & 58.06 & 61.38 & 89.96 & 66.81 \\
\hline 34 & 47.21 & 49.53 & 49.35 & 53.02 & 53.27 \\
\hline 36 & 47.39 & 47.66 & 45.47 & 50.39 & 47.21 \\
\hline 44 & 41.15 & 44.24 & 45.04 & 46.48 & 48.04 \\
\hline 50 & 44.99 & 47.03 & 46.98 & 47.32 & 50.35 \\
\hline \multirow[t]{2}{*}{57} & 43.14 & 50.67 & 49.20 & 49.56 & 52.20 \\
\hline & \multicolumn{5}{|c|}{ Unfertilized Column 4} \\
\hline Day & $\begin{array}{l}5.7 \mathrm{~cm} \\
\text { Depth }\end{array}$ & $\begin{array}{c}11.8 \mathrm{~cm} \\
\text { Depth }\end{array}$ & $\begin{array}{l}17.7 \mathrm{~cm} \\
\text { Depth }\end{array}$ & $\begin{array}{l}26.5 \mathrm{~cm} \\
\text { Depth }\end{array}$ & $\begin{array}{c}38.3 \mathrm{~cm} \\
\text { Depth }\end{array}$ \\
\hline 1 & 49.08 & 47.88 & 54.64 & 53.79 & 52.93 \\
\hline 8 & 34.30 & 31.61 & 41.03 & 44.54 & 44.67 \\
\hline 15 & 33.19 & 42.55 & 41.17 & 51.59 & 46.71 \\
\hline 22 & 37.08 & 39.97 & 41.28 & 47.48 & 49.49 \\
\hline 29 & 52.02 & 50.64 & 53.22 & 54.76 & 76.10 \\
\hline 34 & 47.05 & 47.88 & 49.51 & 51.19 & 51.95 \\
\hline 36 & 51.21 & 42.12 & 44.29 & 44.76 & 48.31 \\
\hline 44 & 47.84 & 42.41 & 43.72 & 50.51 & 48.00 \\
\hline 50 & 43.14 & 47.12 & 45.42 & 49.72 & 49.74 \\
\hline 57 & 46.87 & 44.76 & 46.75 & 51.39 & 49.49 \\
\hline
\end{tabular}


Table A-2: Tables showing (A) major cation and anion concentrations in artificial rainwater and (B) major anion concentrations in fertilizer utilized in Chapter 2.

A.

$\begin{array}{cc}\text { Analyte } & \text { Concentration }\left(\mathrm{mg} \mathrm{L}^{-1}\right) \\ \mathrm{Cl}^{-} & 0.25 \\ \mathrm{SO}_{4}{ }^{2-} & 2.2 \\ \mathrm{NO}_{3}{ }^{-} & 2.6 \\ \mathrm{Na}^{+} & 0.10 \\ \mathrm{Ca}^{2+} & 0.48 \\ \mathrm{Mg}^{2+} & 0.08 \\ \mathrm{~K}^{+} & 0.05\end{array}$

B.

Analyte

$\mathrm{Cl}^{-}$

$\mathrm{SO}_{4}{ }^{2-}$

$\mathrm{PO}_{4}^{3-}$
Concentration $\left(\mathrm{mg} \mathrm{L}^{-1}\right)$

0.2

35 